3.

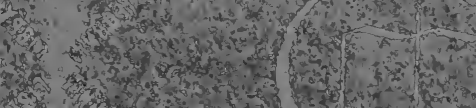

3. Me

5. 5 3.

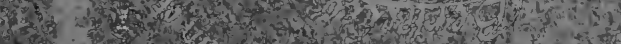

ato

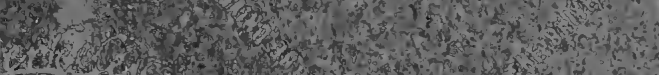

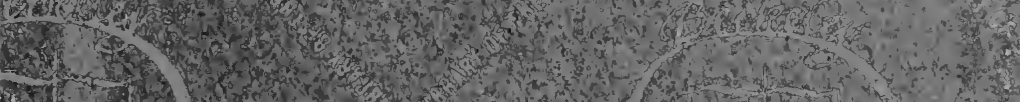

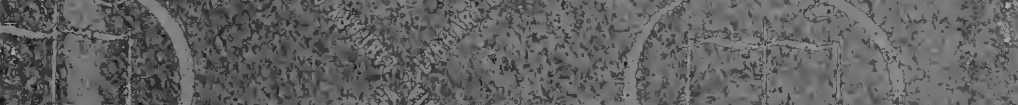

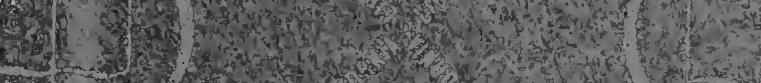

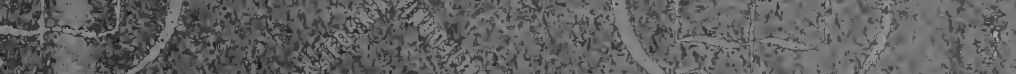

2.

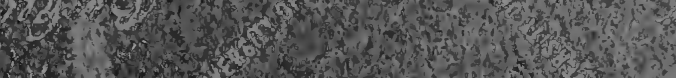

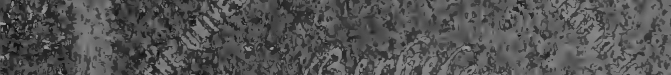

(25)

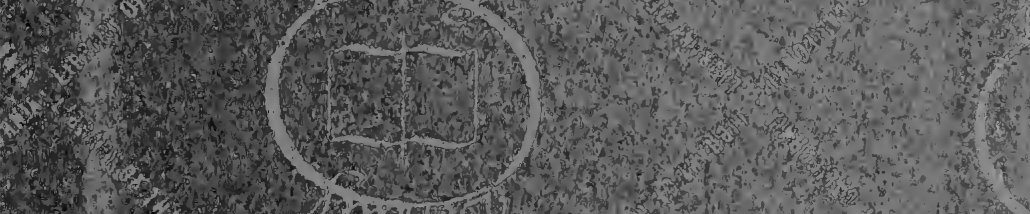

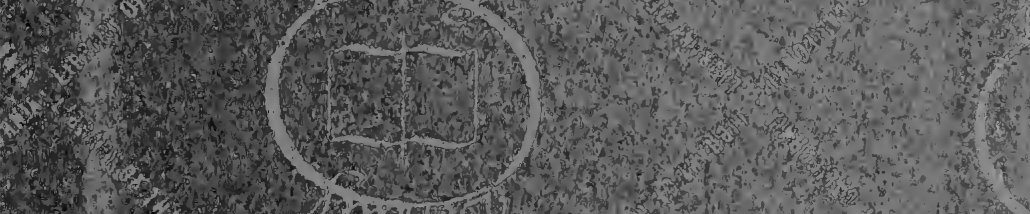

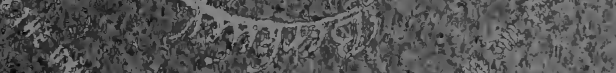

(1)

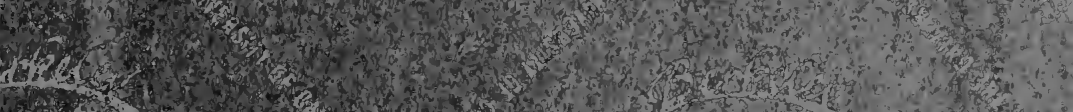

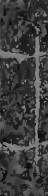
4
s.
1)

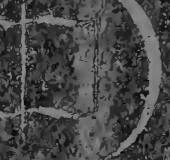

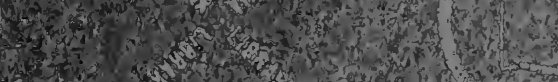

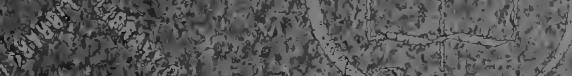
1. . .

5.105.

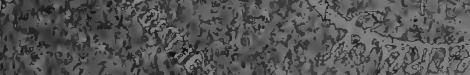

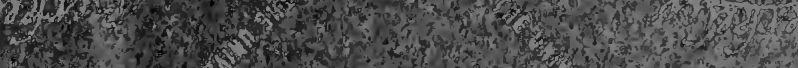

2.

3.1.

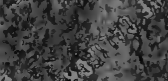

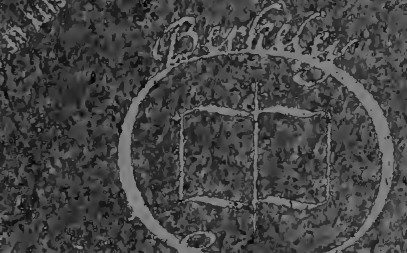

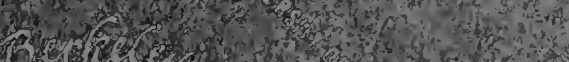

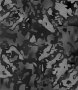

(4.).

10.

of 10 iो

8

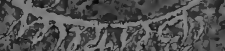
of

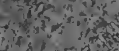

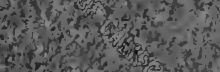

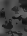

(3)

nus.

int

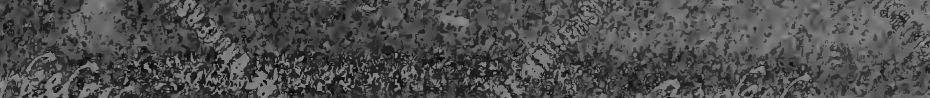

W.

1)

if 



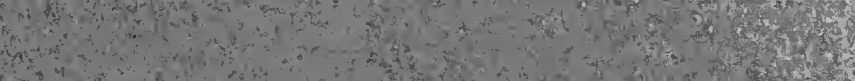

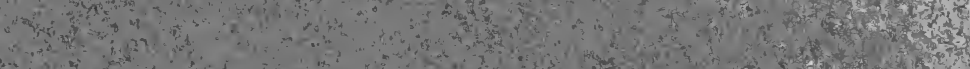

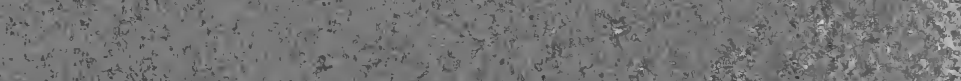
$2+2+201+20$

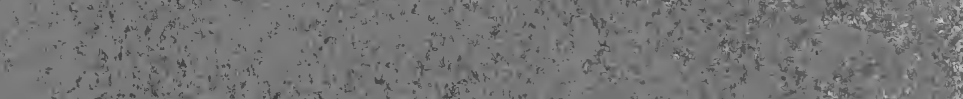

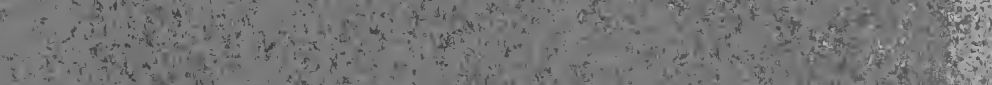
and

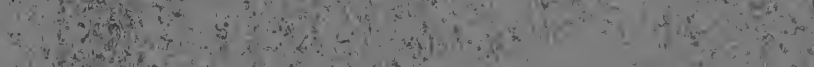
$3+2+1$

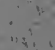
$\therefore$

$$
y^{2}+4
$$$$
x^{2}+x^{2}+2
$$$$
\frac{4}{4+2}
$$

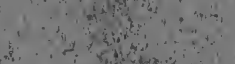

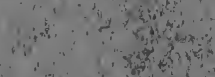$$
\text { testion }
$$$$
\text { tis }
$$$$
\text { कo }
$$

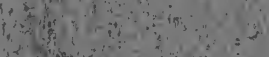

$+3 x^{2}+3$

$$
n^{2}+x^{2}
$$

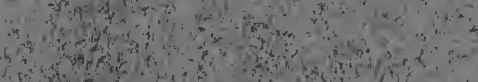

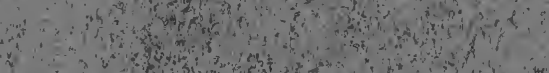
and

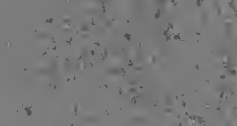

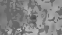

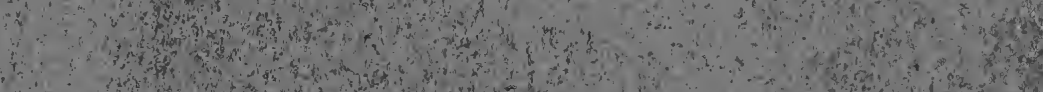

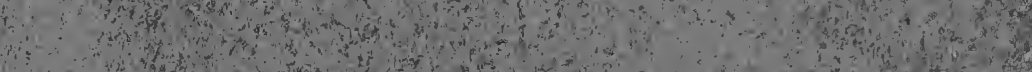

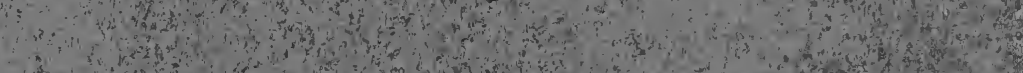
3.

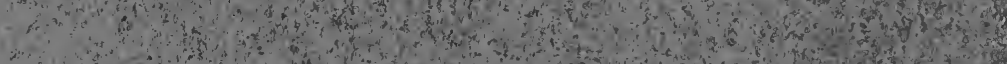

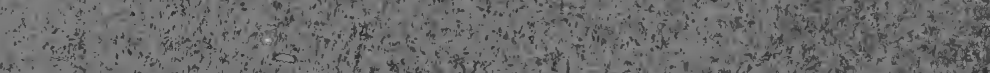

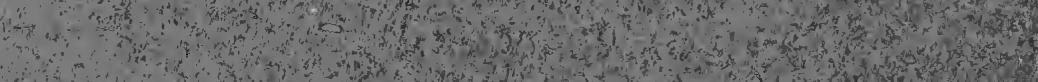

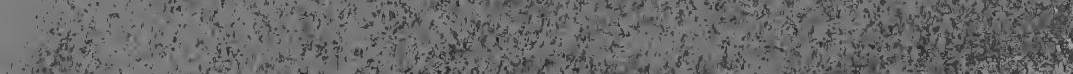


Digitized by the Internet Archive in 2007 with funding from Microsoft Corporation 



\section{THE MODERN CORPORATION}




\section{Legal and Business publications of The Ronald press Campany}

229 BROADWAY, NEW YORK

CORPORATE ORGANIZATION.

By THOMAS CONYNGTON, of the New York Bar. 400 pp. $6 \times 9$ in. 1908. Buckram binding.

CORPORATE MANAGEMENT.

By THOMAS CONYNGTON. Third Edition. 422 pp. $6 \times 9$ in. 1909. Buckram binding.

CORPORATION LAWS OF ALI STATES.

By M. U. OVERLAND, of the New York Bar. 500 pp. $6 \times 9$ in. I909. Buckram binding.

MAINE CORPORATIONS.

By H. M. HEATH, of the Maine Bar. 300 pp. $6 \times 9$ in. 1907. Buckram binding.

NEW YORK CORPORATIONS.

By RICHARD HARRISON, of the New York Bar. 500 pp. $6 \times 9$ in. I909. Second Edition. Revised and Enlarged. Buckram binding.

CONDITIONAL, SALES.

By FRED BENSON HARING, of the Buffalo Bar. 370 pp. $6 \times 9$ in. I909. Buckram binding.

PARTNERSHIP REIATIONS.

By THOMAS CONYNGTON. 22I pp. $6 \times 9$ in. 1905. Buckram binding.

FINANCING AN ENTERPRISE.

By FraNCIS COOPER. 545 pp. $53 / 4 \times 81 / 2$ in. 1909. Third Edition, 2 vols. Buckram binding.

CORPORATE FINANCE AND ACCOUNTING. By H. C. BentLey, C. P. A. 500 pp. $6 \times 9$ in. I908. Buckram binding.

DESCRIPTIVE PRICE LIST ON APPLICATION 
A PRACTICAL WORK ON THE CORPORATE FORM AS USED FOR PRIVATE ENTERPRISES

\title{
THE
}

\section{MODERN CORPORATION}

Its Mechanism, Methods, Formation and Management

\author{
BY \\ THOMAS CONYNGTON \\ OF THE NEW YORK BAR \\ Author of \\ "Corporate Organization," "Corporate Management," etc.
}

FOURTH EDITION

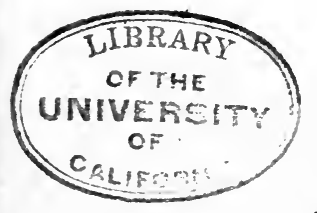

THE RONALD PRESS

NEW YORK

1910 


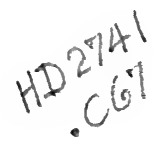

Sheness

Copyright 1902

BY

The Ronald Press

Copyright 1905

BY

The Ronald Press Company

\section{Copyright 1908}

BY

The Ronald Press Company

Copyright 1910

BY

The Ronald Press Coypany 


\section{PREFACE.}

In this fourth edition of "The Modern Corporation" the author has made the various changes necessary to bring the volume up-to-date, has made such minor emendations in the text as seemed desirable, and has added to the number of its forms. The most important change is, however, in the arrangement of the volume; the consideration of the mechanism and management of corporations now preceding the discussion of their organization instead of following it as before. The former arrangement was logical but, from the practical standpoint, one unfamiliar with corporate matters requires a knowledge of corporate mechanism and procedure and of the ends to be attained by incorporation before this latter subject can be intelligently considered, and for this reason the change referred to has been made.

Speaking generally, however, "the endeavor has been to follow out and extend the design of the original work,-to give a general view of the corporate system, to summarize the objects, methods and advantages of the corporate form, to show the ready adaptation of the modern corporation to the needs of ordinary business, to outline the manner of its formation and to give the important rules of its procedure,-in short to present from a practical stand- 
point, the facts, directions and general information concerning corporations that every man of affairs should know and that those responsible for or interested in corporations must know if they would properly perform their duties or protect their interests."

The forms added to the present edition are those practical forms which are needed in the management of a corporation and are also desirable in any general consideration of corporate organization and procedure. They were excluded from former editions by the limits of space.

In closing, the author wishes to express his appreciation of the very kindly reception accorded the present work, and to trust that the new edition may even better fill the ends for which the volume is designed.

Thomas Conyngton.

New York, September I, 1909. 


\section{TABLE OF CONTENTS.}

PART I. THE CORPORATE SYSTEM.

Chapter I. The Corporation.

$\S$ I. Nature.

2. Classification.

3. (a) Corporations without Capital Stock.

4. (b) Corporations with Capital Stock.

5. (I) Corporations for General Business Purposes.

6. (2) Corporations for Public Service.

7. (3) Corporations for Financial Purposes.

8. Joint-Stock Companies.

Chapter II. Stock Corporations.

\&. 9. Distinctive Features.

Io. (a) Creation by the State.

II. '(b) Limited Powers.

12. (c) Limited Liability.

13. (d) Legal Entity of Corporation.

14. (e) Permanence.

15. (f) Stock System.

I6. (g) Corporate Mechanism.

17. (h) Attractiveness to Investors.

PART II. CORPORATE MECHANISM AND MANAGEMENT.

\section{Chapter III. The Charter.}

$\S$ I8. Definition-Synonyms.

19. Charter Powers-General.

20. (a) To Sue and be Sued.

2I (b) To Use a Seal.

22. (c) To Buy, Sell and Hold Property.

23. (d) To Appoint Directors, Officers and Agents. 
24. (e) To Make By-Laws.

25. (f) To Dissolve Itself.

26. (g) To Do All Things Necessary.

27. Charter Powers-Special.

28. Things Ultra Vires.

29. Amendment of Charter.

\section{Chapter IV. By-Laws.}

30. Definition.

3I. Adoption.

32. Amendment.

33. Enforcement.

$\S 34$. Capital Stock.

Chapter V. Stock.

35. Capital Stock vs. Capital.

36. Unissued and Issued Stock.

37. Full-Paid Stock.

38. Common Stock.

39. Preferred Stock.

40. Treasury Stock.

4I. Acceptance of Subscriptions.

42. Certificates of Stock.

43. Issuance of Certificates.

44. Transfers of Stock.

45. Lost Certificates.

46. Stock and Transfer Books.

Chapter VI. Stockholders and Their Meetings.

$\S$ 47. What Constitutes a Stockholder.

48. Rights of Stockholders.

49. Powers of Stockholders.

50. Liabilities of Stockholders.

5r. Meetings.

52. Annual Meeting.

53. Special Meetings.

54. Notice of Meeting.

55. Quorum.

56. Voting. 
57. Proxies.

58. Election of Directors.

59. Officers of Meetings.

Chapter VII. Directors and Their Meetings.

$\S 60$. Status and Function of Directors.

6r. Number and Authority.

62. Liabilities.

63. Qualifications.

64. Vacancies.

65. Classification.

66. Regular Meetings.

67. Special Meetings.

68. Notice of Meetings.

69. Quorum.

70. Election of Officers.

71. Compensation of Directors.

72. Power to Pass By-Laws.

73. Executive Committee.

74. Finance Committee.

\section{Chapter VIII. Officers.}

$\S$ 75. Enumeration; Qualifications.

76. Vacancies and Removals.

77. Liabilities of Officers.

78. Compensation of Officers.

79. Powers and Duties of Officers.

80. The President.

8r. The Vice-President.

82. The Secretary.

83. The Treasurer.

84. General Manager.

85. Counsel and Auditor.

\section{Chapter IX. The Corporate Records.}

$\S$ 86. The Treasurer's Books.

87. The Secretary's Books.

88. Minute Book. 
89. Stock Certificate Book.

90. Transfer Book.

9I. Stock Ledger.

Chapter X. Dividends and Finances.

$\S$ 92. Dividends.

93. Working Capital.

94. Debt.

95. Bank Deposits.

Chapter XI. Sundry Details.

$\S$ 96. Corporate Offices.

97. Corporate Seal.

98. Execution of Contracts.

PART III. CORPORATE ORGANIZATION.

Chapter XII. Incorporation.

$\S$ 99. Subscription Lists.

roo. Application for Incorporation.

ror. (a) Incorporators.

102. (b) Name of Corporation.

103. (c) Purposes.

104. (d) Capitalization.

I05. (e) Shares.

106. (f) Location.

107. (g) Duration.

108. (h) Number of Directors.

109. (i) Directors for the First Year.

I Io. (j) Charter Subscriptions.

III. (k) Classification of Stock.

II2. (1) Cumulative Voting.

II3. ( $\mathrm{m}$ ) Holding Stock in Other Companies.

II4. (n) Powers of Directors.

II5. (o) Limitations on Salaries and Indebtedness.

II6. Execution of Certificate.

I17. Filing and Recording.

II8. Fees and Expenses.

II9. Books, Stock Certificates and Seal. 
Chapter XIII. First Meeting of Stockholders.

§ I20. Preliminary.

I2I. Opening the Meeting.

122. Adoption of By-Laws.

123. Election of Directors.

124. Proposal to Exchange Property for Stock.

125. Resolution Approving Exchange.

126. Other Business.

Chapter XIV. First Meeting of Directors.

$\S$ I27. Preliminary.

I28. Opening the Meeting.

129. Election of Officers.

130. Exchange of Property for Stock.

I3I. Designation of Bank.

132. Other Business.

133. Adjournment.

Chapter XV. Protection of Minority.

§ I34. General.

135. Cumulative Voting.

136. Non-Voting Stock.

I37. Stock Classification.

I38. Voting Trusts.

I39. Limitations on Expenditures.

I40. Restrictions on Amendments.

14I. Restrictions on the Voting Power.

Chapter XVI. From Partnership to Corporation.

142. General.

I43. Name.

144. Usual Arrangements.

145. Special Adjustments.

146. Preliminary Contract.

147. Organization of Corporation.

148. Transfer of Business.

149. Conduct of Business under New Form.

I50. Changing Books. 


\section{PART IV. CORPORATE FORMS.}

Chapter XVII. Subscription Lists.

Form.

I. Subscription List. Usual Form.

2. Subscription List. Trustee's.

3. Subscription Blank. Individual.

Form.

Chapter XVIII. Stock Certificates.

4. Stock Certificate with Stub.

5. Preferred Stock Certificate.

6. Assignment of Stock Certificate. In Blank.

7. Assignment of Stock Certificate. Complete.

Form.

Chapter XIX. Charter Forms and State Fees.

8. New York Charter.

9. New Jersey Charter.

Io. Arizona Charter.

II. Comparative Table. Organization Expenses.

12. Comparative Table. Annual Franchise Taxes.

Chapter XX. By-Laws.

Form.

13. By-Laws.

14. Certification of By-Laws.

15. Certified Extract from By-Laws.

Chapter XXI. First Meetings.

Form.

I6. Proxy. First Meeting of Stockholders.

17. Call and Waiver. First Meeting of Stockholders.

18. Call and Waiver. First Meeting of Directors.

19. Issuance of Stock for Property. Proposal.

20. Issuance of Stock for Property. Stockholders' Resolution.

2I. Issuance of Stock for Property. Directors' Resolution. 
Form.

Chapter XXII. Minutes of First Meetings.

22. Minutes. First Meeting of Stockholders.

23. Minutes. First Meeting of Directors.

\section{Chapter XXIII. Calls and Notices.}

Form.

24. Notice of Annual Meeting.

25. Notice of Annual Meeting. Publication.

26. Call and Waiver. Special Meeting of Stockholders.

27. Call for Special Meeting. Stockholders'.

28. Notice of Special Meeting. Stockholders'.

29. Notice of Regular Meeting. Directors'.

30. Call and Waiver. Special Meeting of Directors.

30a. Call for Special Meeting. Directors'.

3I. Notice of Special Meeting. Directors'.

Form.

\section{Chapter XXIV. Proxies.}

32. Simple Proxy. Unlimited.

33. Formal Proxy. Annual Meeting.

34. Revocation of Proxy.

Form.

\section{Chapter XXV. Minutes.}

35. Annual Meeting of Stockholders.

36. Regular Meeting of Directors.

37. Special Meeting of Stockholders.

38. Adjourned Meeting of Stockholders.

39. Special Meeting of Directors.

Form.

Chapter XXVI. Motions and Resolutions.

40. Motion. To Rèceive and File Report.

4I. Motion. To Pay Bills.

42. Motion. To Pay Disputed Account.

43. Motion. To Purchase Engines.

44. Resolution Authorizing Contract. (Directors'.)

45. Resolution Declaring Dividend. (Directors'.)

46. Resolution Authorizing Sale of Assets. (Stockholders'.) 
Form.

Chapter XXVII. Signatures and Certifications.

47. Official Signatures.

(a) Informal.

(b) Formal.

48. Corporate Signatures.

(a) Incomplete. By Stamp.

(b) Completed.

(c) Attestation of Seal.

(d) Testimonium and Formal Signatures.

49. Corporate Endorsements.

(a) Simple.

(b) For Deposit.

50. Acknowledgment of Corporate Instrument.

5I. Treasurer's Affidavit.

52. Certified Resolution for Bank.

53. Certified Extract from Minutes.

54. Certified Extract from Minutes. Formal.

Form.

Chapter XXVIII. Checks, Notes and Contracts.

55. Corporate Check.

56. Corporate Note. Signature by President.

57. Corporate Note. Signature by Treasurer.

58. Corporate Contract.

59. Assignment of Contract.

Form.

Chapter XXIX. The Corporate Records.

60. Stock Ledger.

6I. Transfer Book.

62. Transfer Book. Condensed Form.

63. Dividend Book.

Form.

Chapter XXX. Notices.

64. Instalment Notice.

65. Dividend Notice. Mailing.

66. Dividend Notice. Publication.

67. Notice of Election as Director.

68. Notice of Election as Director. Acceptance Requested. 
TABLE OF CONTENTS.

\section{Chapter XXXI. Sundry Corporate Forms}

Ballots.

Form.

69. Ballot. Annual Meeting.

69a. Ballot. Cumulative Vioting.

Resignations.

Form.

70. Resignation of Director.

71. Resignation of President.

Miscellaneous Instruments.

Form.

72. Corporate Receipt.

73. Corporate Bill of Sale.

74. Bond. Treasurer's.

75. Bond. Lost Stock Certificate.

76. Committee Report. 
) 


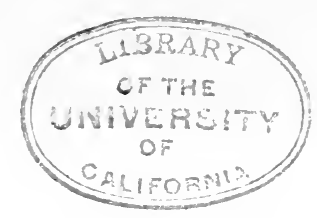

\section{THE MODERN CORPORATION.}

\section{PART I.-THE CORPORATE SYSTEM.}

\section{CHAPTER I. \\ THE CORPORATION.}

\section{$\S$ I. Nature.}

A corporation is an artificial person, created or authorized by the law for some particular purpose or purposes. It has, therefore, only those rights and powers which are given it by the law. These rights and powers vary in the different states but are in all cases sufficient for the demands of ordinary business.

A corporation is usually composed of a number of persons associated together, though it may, and sometimes does, consist of but one or two members. These members, or stockholders, are not, however, the corporation. They compose it but the corporation has a name, an entity and an existence of its own, entirely apart and distinct from that of these members. Under its corporate name it may conduct business, make contracts and bring suit. So absolutely different is the corporation's existence from that of its stockholders 
that it may enter into contracts with these latter, may. sue them or be sued by them. (See $\S$ I3.)

In the famous case of the Trustees of Dartmouth College vs. Woodward, Chief Justice Marshall defined a corporation as "an artificial being, invisible, intangible, and existing only in contemplation of the law." In other words the corporation exists, and, through officers and agents, may carry on its business, but there is no individual or group of individuals who can legitimately claim to be the corporation. They may own or control or represent the corporation, but they can not be the corporation.

\section{§ 2. Classification.}

Corporations are used for such a wide diversity of objects that any classification based on the purposes for which they are formed overlaps and is apt to be confusing. The government of a city or the management of a college, the activities of a church or the operations of an industrial combination, the administration of an estate or the control of a railway system, may all be efficiently conducted under the corporate form. We speak generally of manufacturing, municipal, religious, educational and banking corporations and the like, thus roughly grouping them according to their purposes, but the classification is not entirely satisfactory.

A logical classification is that which separates all corporations into (I) public and (2) private corporations. Public corporations are those formed by the community for its own governmental purposes, as in 
cities, villages and towns. These are called municipal corporations. In the Dartmouth College case, already quoted, it was said that "strictly speaking, public corporations are such only as are founded by the government for public purposes where the whole interests belong also to the government." All other corporations are private corporations.

Corporations formed to conduct public utilities, such as railroads, turnpikes and telegraph systems, or to supply water, gas and electricity, are frequently termed quasi-public corporations, but, if they are conducted for private gain, they are properly classed as private corporations, even though the State may own part of their stock.

Private corporations may be divided into corporations without capital stock and corporations with capital stock.

\section{§ 3. (a) Corporations without Capital Stock.}

Most religious, educational, charitable and social organizations belong to this class. They are nonstock, or membership corporations. In some cases certificates of membership are issued to the members, but these are not stock certificates and are not usually transferable. When corporate action is taken each member has one vote without regard to the amount of his financial interests, if any, in the corporation. Mutual insurance companies are non-stock corporations, as are also stock exchanges and other similar organizations. Curious questions sometimes arise as to the rights and interests of the members of such 
corporations, but the subject is not of sufficient general interest to justify its discussion here. The body of modern corporation law has to do with the stock corporation.

\section{§ 4. (b) Corporations with Capital Stock.}

Stock corporations have a capital stock divided into shares, usually of like amount, which are evidenced by transferable certificates of stock. These stock certificates are issued to the members of the corporation, who are termed stockholders, the certificates evidencing the number of shares to which their owners are entitled.

The ultimate control of the corporation rests with the stockholders, who act in meetings and by vote. Each share of stock usually entitles its owner to one vote in stockholders' meetings, hence those owning a majority of the shares control the corporation. When profits are to be divided, they are distributed among the stockholders in proportion to the number of shares owned by each.

On account of the convenience of the system, all corporations intended for profit are organized as stock corporations.

Stock corporations may be conveniently divided into the following classes:

(I) Corporations for general business purposes.

(2) Corporations for public service.

(3) Corporations for financial purposes. 


\section{§ 5. (I) Corporations for General Business Purposes.}

This class includes the greater number of existing corporations. In most states of the Union general laws have been passed providing that upon compliance with simple prescribed formalities and payment of certain moderate fees companies of this class may be incorporated. In a few states corporations may also be authorized by special act of the legislature, but the practice prevailing in most of the states permits incorporation only under the provisions of general laws, the benefits of which may be enjoyed by all alike. Many of the states have constitutional prohibitions against special incorporations. (See $\S$ Io.)

The law and procedure relating to corporations for general business purposes, such as manufacturing, mining and industrial corporations, make up the great body of modern corporation law. The present work treats primarily of this class of corporations,

\section{§6. (2) Corporations for Public Service.}

The corporations which control railways, telegraph and telephone lines and which furnish transportation, light, water and power in our great cities, form another exceedingly important class. These corporations are allowed, under certain restrictions, to exercise the right of eminent domain, and in some cases are given special and exclusive privileges in the public ways.

The peculiar nature of the privileges conferred upon this class of corporations, and the not infrequent re- 
sulting abuse of their monopolistic powers, render them the subject of constant and increasing legislative restriction and regulation. The laws enacted for this purpose apply solely to this class of corporations and are mostly outside the scope of the present volume. It is to be noted, however, that these corporations are subject to the general corporate law and procedure applicable to all stock corporations, as well as to those special regulations applicable only to public service corporations.

\section{§ 7. (3) Corporations for Financial Purposes.}

Under this head are included all banks, trust companies, insurance companies, guaranty companies, building associations and other similar institutions handling the funds, savings or investments of the public. The laws under which these may be organized usually require evidence of substantial financial responsibility and of actually paid in cash capital. After organization certain detailed reports are required and the corporation is usually subject to some form of governmental supervision. In each state corporations of this class are subject to special statutory regulation, except national banks, which are created and supervised only by the National Government.

In the details of their management, not regulated by special statutes, these financial corporations are subject to the general statutory and common law rules and procedure by which all stock corporations are governed. 


\section{§ 8. Joint-Stock Companies.}

In most of the states a joint-stock company is practically a partnership, authorized by law to act under a corporate name and to issue stock to its members. Thus, as existing under the laws of New York, the joint-stock company has been defined by the State Court of Appeals as "a partnership with some of the powers of a corporation." In some few states, however, partnership associations are permitted in the nature of joint-stock companies, but of such indefinite character that their proper classification has puzzled the courts. In some few other states the term "jointstock company" is loosely and inaccurately applied to the ordinary stock corporation.

Joint-stock companies are sharply distinguished from the corporation by their method of formation and by the liabilities to which their members are subject. Their stock, it is true, is transferable and represents the interests of the members in the profits and property of the business just as in the case of the ordinary corporation, but here the resemblance ceases. Their members are individually liable for the debts of the company exactly as in the partnership, and, whereas a corporation may only be formed by compliance with prescribed statutory requirements, or by special legislative enactment, joint-stock companies are, like partnerships, formed by mere agreement of the members among themselves.

A joint-stock company lacks the most attractive features of the corporation, is of but little real utility, and has never attained any great degree of popularity. 
CHAPTER II.

\section{STOCK CORPORATIONS.}

\section{§ 9. Distinctive Features.}

The distinctive features of a modern stock corporation may be summarized as follows:-

(a) Its creation and regulation by the state.

(b) The limitation of the corporate powers to the objects specified at the time of its creation.

(c) The limitation of the liabilities of the stockholders.

(d) The distinct entity of the corporation for all legal and business purposes.

(e) The permanence of its organization.

(f) The representation of the interests of the stockholders in the corporation by transferable shares of stock.

(g) The corporate mechanism of directors, officers and agents, working under definite rules of action.

These are the most important and characteristic features of corporate existence. They are possessed by every stock corporation, and every organization possessing them is a stock corporation. They em- 
body the peculiar advantages of the corporation over the partnership. They are discussed in the present chapter in the order given.

\section{$\S$ ro. (a) Creation by the State.}

A partnership may be formed by the mere agreement of the parties. A corporation, on the contrary, may be created only by the State. Formerly each corporation was created by a separate legislative enactment. This made the grant of corporate powers a legislative favor to the recipients and resulted in much abuse and corruption. To avoid this the various states of the Union have passed general laws governing the formation of corporations. These laws vary in the different states in minor details. All are alike in their general plan and scope. Under them qualified persons making due application and paying certain established fees to the state, are granted a charter authorizing them to organize a corporation for the specified purposes, if legitimate, in accordance with the terms of their application. (See Ch. XII.)

\section{$\S$ II. (b) Limited Powers.}

An individual or a partnership may engage in any business that seems best, and may change from one business to another at pleasure. A corporation, on the contrary, is limited to those purposes enumerated in its charter, and has no authority to engage in any other business or venture unless authorized thereto by amendment of its charter. 
Formerly in most states a corporation could be organized for only one purpose or line of business. Of late years the corporation laws of many states have been so changed that more than one purpose may be enumerated, and it is possible to give a modern corporation very broad powers. In the case of the great industrial combinations this enumeration of diverse purposes has been carried to such an extreme that almost every restraint has been removed, and it would be difficult to find any industry or business that can not be undertaken. (See $\S$ I9.)

Directors of corporations have no power to undertake in the corporate name enterprises which are not permitted by the charter. Such matters are in legal parlance termed "things ultra vires." (See § 28.)

\section{$\S$ I2. (c) Limited Liability.}

Subscribers to the stock of a corporation are liable to the corporation for their subscriptions. If these have not been paid, the corporation, or its creditors in case of its insolvency, can compel payment just as payment of any other amounts due the company can be compelled. Also if subscriptions are accepted by the corporation at less than par, corporate creditors can usually force payment of such additional amount as will render the stock full-paid. Beyond this liability, known as the subscription liability, there is in most states no individual liability whatsoever on the part of the stockholders for any indebtedness of the corporation. (See $\S \S 37,50$.) 
This freedom from liability is the great inducement to corporate investment and the use of the corporate form generally. It is the exact opposite of the rule that obtains in the partnership, where, if credit is given, it is extended on the individual responsibility of the partners and each is held legally answerable for all the partnership debts. In the corporation, on the other hand, if credit is given, it is extended on the reputation and solvency of the corporation alone, and, provided all stock is paid in full, the corporation alone can be held.

In some few states this general rule has been varied, special liabilities having been created by statute. These liabilities are, however, exceptional and not characteristic of the corporation. In the great majority of the states the stockholder when once his stock has been paid for in full, is liable neither to assessment by the corporation nor to action by its creditors. If his corporation becomes insolvent he may lose his investment, but he need fear no further involvement.

\section{§ 13. (d) Legal Entity of Corporation.}

The distinct legal entity of the corporation may best be shown by a comparison of the relations of stockholders to their corporation and of members of a firm to their partnership. The difference is radical.

A partnership is an association of which each partner is an integral and inseparable part. Hence each partner represents the partnership fully, can make contracts for it without consultation with other part- 
ners and can bind it by his action. On the other hand he can not contract with his partnership, bring suit against it, or be sued by it, any more than he could so act with or against himself.

A corporation on the contrary is itself a legal entity, distinct from its stockholders. These stockholders as individuals do not represent it, can not make contracts for it, nor bind it in any way. Each may, however, deal with the corporation as with a stranger, may contract with it, may sue it, may be sued by it.

A partnership, even though it may have a trade name can not sue or be sued under this name, but in every action at law the name of every partner must appear.

The corporation, on the contrary, may bring suit in its own name and may be sued in like manner, without the necessity of naming its stockholders or any of them.

The partnership, in short, is merely an association of the people who compose it, while the formation of a corporation creates, for all legal purposes, a new personality, having a legal existence and rights of its own distinct from those of its members and stockholders. It is true that this doctrine of the distinct legal entity of a corporation is a legal fiction, but for all practical business purposes it is an actual fact upon which is based almost all existing corporate law and procedure.

The courts recognize this doctrine fully, and, except in certain cases of fraud, treat the corporation as a complete and competent legal personality. 


\section{§ I4. (e) Permanence.}

A partnership may be dissolved at any time, at the will of any partner, and is necessarily dissolved if a partner dies, becomes insolvent or sells out to a stranger. A corporation, on the contrary, continues for the term of its existence, uninterrupted by the dissatisfaction, financial embarrassment, death or retirement of its stockholders. Its entire membership may change again and again, but the corporation continues. The old writers were fond of comparing it to a river, which remains always the same though the water that composes it is constantly changing.

In some states corporations are only chartered for a limited period such as twenty or fifty years. Unless the charter or statutes limit the term of existence, or unless the constitution or statute law of the state expressly reserves the right to repeal or amend charters, the duration of a corporation is technically at least perpetual. Many modern charters state boldly that the duration of the corporation shall be perpetual.

The duration of a corporation is usually terminated (I) by voluntary dissolution, (2) by the expiration of the period for which it was formed, (3) by its insolvency or (4) by forfeiture of its charter to the State for misuse, non-use or abuse of its power. These are the only legal methods by which a corporation may be terminated. (See $\S \S 25$, ro7.)

In most of the states, the right to repeal or amend corporate charters is reserved by the state. This power, however, may not be exercised arbitrarily or unreasonably. 


\section{§ I5. (f) Stock System.}

The division of the stock of the corporation into shares represented by stock certificates, transferable by indorsement, is one of the most convenient features of the modern corporate system. It permits the investment of varying amounts, and gives each investor due proportionate interest both in the management and in the resulting profits of the business. It provides a ready method for withdrawal of his investment by the sale of part or all of the stockholder's interest to some other investor. In case of the death of a stockholder it renders the transfer or division of his interest a simple matter. It is in striking contrast to the complexity, cumbersomeness and difficulty of transferring an interest in an ordinary partnership. (See Ch. V, vI.)

\section{§ I6. (g) Corporate Mechanism.}

A corporation is created by the grant of a charter from the State. This instrument in general terms defines the rights and powers of the corporation. After this charter has been allowed the incorporators hold a meeting, and adopt by-laws, which are the general rules for the government of the corporation and which lay down the lines along which the business of the corporation is to be conducted. The stockholders also elect a board of directors, which, under the limitations and regulations of the charter and by-laws, controls and manages the business and property of the corporation.

The directors at their first meeting, elect officers 
and take such other action as may be necessary to inaugurate the corporate activities. Thereafter they hold their meetings from time to time as may be required by the by-laws or the necessities of the business. In addition to the elected officers, they may appoint such other agents as may be necessary. These officers and agents are subordinate to the board and must obey its instructions.

The respective powers, duties and relations of the stockholders, the directors and the officers, are all well understood and clearly defined. (See $\S \S 49,6$ r ; also Ch. viII.)

\section{§ 17. (h) Attractiveness to Investors.}

As a consequence of the advantages enumerated, and because of the liabilities and inconveniences of the partnership, the corporate form is peculiarly attractive to the investing public. Created by the State for a fixed period, it is not liable to sudden or unexpected termination. It moves in well defined grooves and the rights and liabilities of all concerned are defined by law and well settled by custom. It permits investment to a definite extent without indefinite or continuing liability and without the necessity of the investor becoming identified with the management. Also an interest may be secured and then sold, transferred or transmitted to posterity with a minimum of formality and at nominal expense.

For these reasons, whenever outside capital is to be secured for an enterprise, or capital already engaged is to be increased, recourse is naturally had to the corporate form. 


\section{PART II.-CORPORATE MECHANISM AND MANAGEMENT.}

\section{CHAPTER III.}

\section{THE CHARTER.}

\section{$\S$ I8. Definition-Synonyms.}

The terms, certificate of incorporation, articles of association, etc., are synonymous with the older and briefer word, charter. A charter is the formal authority from the State for the existence of a corporation,the legislative fiat by which it is created. It is to the corporation what a constitution is to a civil government. It is the foundation upon which the corporate structure is built. (See Forms 8, 9, Io.)

Charters for ordinary business corporations are not granted by the national government, the matter being left entirely with the states. The general government does, however, grant charters for national banks, has chartered sundry railway companies to build interstate lines and it is probable that it could constitutionally incorporate companies for other purposes,- that is for the purposes of ordinary business. Important ad- 
vantages would result from a national incorporation law accompanied by some measure of governmental supervision. As it is, the corporation laws of the various states differ greatly as to detail and this lack of uniformity occasions much inconvenience.

The charter creates the corporation and authorizes certain specified individuals to organize it and conduct its operations. Such charter may include the grant of a franchise, as, for instance, for the construction of a bridge, a railway or other work, or may merely give the right to conduct some ordinary specified business.

As has been stated, charters were formerly granted only by special legislative enactment. Now they may be secured under general laws and in many states may be secured in no other way. (See $\S$ roo.) Under these general laws incorporation has become a comparatively simple matter, the number of incorporations has enormously increased and the corporate form is now employed for almost every variety of human effort and enterprise.

\section{§ 19. Charter Powers-General.}

The grant of a charter bestows upon a corporation all the powers properly specified in the charter application. In addition to these specified powers-which are usually those necessary to conduct the business or enterprise to -be undertaken by the corporationthe charter confers certain general powers whether specified or otherwise. These general powers are as follows : 
(a) To sue and be sued.

(b) To use a seal.

(c) To buy, sell and hold property.

(d) To appoint directors, officers and agents.

(e) To make by-laws.

(f) To dissolve itself.

(g) To do all things necessary.

These are discussed in order in the following sections :

§ 20. (a) To Sue and be Sued.

A partnership may be sued only by joining all the partners. That is, each partner must be named separately and be made a party to the action. A corporation may sue or be sued under its corporate name just as may an individual. No mention need be made of its stockholders. A summons may be served on any managing officer, on any director or on an agent in charge of the corporate affairs.

\section{§2I. (b) To Use a Seal.}

This was once a highly valued privilege, but its original significance has largely disappeared. Formerly the seal was the essential feature of the corporate signature. Now the corporate signature may be affixed by any properly authorized agent without the use of the seal, save in those few cases where an individual must use a seal, as in the conveyance of real estate or the execution of a bond.

The seal of a corporation is still, however, an important adjunct. It is used, without regard to its 
legal necessity, in the execution of all formal instruments and is impressed on every certificate of stock. It is also used in the certification of resolutions, bylaws, etc. The custody of the seal usually rests with the secretary of the corporation. (See $\S 97$ and Form 48.)

\section{§22. (c) To Buy, Sell and Hold Property.}

The general statement of this power must be taken with some qualifications. The property must be such as pertains to the business of the corporation and such as it is permitted to hold under the laws. In some states the ownership of land by corporations is restricted. Also in many states a corporation may not hold shares of stock in another corporation. This was formerly the general rule but in recent years it has been modified in some states, as in New York where such power is granted if set forth in the charter, and in others has been abrogated altogether, as in New Jersey where a corporation may hold stocks as freely as an individual.

\section{§ 23. (d) To Appoint Directors, Officers and Agents.}

This power is absolutely necessary as the corporation can act only through such representatives. The stockholders at their annual meeting elect directors who have charge of and manage the corporate affairs. These directors then meet and elect a president, a treasurer, a secretary and such other officers as may be desired. Agents may be appointed by the directors or by the officers, when authorized thereto. 


\section{§ 24. (e) To Make By-Laws.}

The by-laws are adopted by the stockholders. They are the working rules of the corporation and provide for the details of its operation. The by-laws are subordinate to the laws of the land and to the charter of the corporation, and their provisions must not be inconsistent with these higher authorities. Under this limitation, however, the by-laws have wide scope.

As the stockholders make the by-laws, they can through these by-laws exercise a general control over the corporation and its affairs and this is the only way in which they can make their wishes effective. The by-laws therefore occupy a very important position in matters corporate. (See Ch. Iv; also $\S \S 49,72$ and Form I3.)

\section{$\S 25$. (f) To Dissolve Itself.}

When a corporation has failed in its object, or has become unprofitable, or has completed its intended course, or has disposed of its business and property, its dissolution may become desirable. Formerly this was a proceeding of son difficulty as the unanimous consent of all the stockhorders was generally required. Now, however, in most states special laws have been enacted whereby some specified majority of the stockholders by simple statutory proceedings may dissolve the corporation. In such case the assets are sold, and, after payment of any corporate debts, any remaining funds are divided pro rata among the stockholders.

It sometimes occurs, and more particularly among 
corporations formed for speculative purposes, that a corporation fails and has absolutely nothing left of material value. Under these circumstances the trouble and expense of a formal dissolution are at times avoided by the very simple expedient of abandoning the corporation. This, while not recognized by the law, works a virtual dissolution. ( $\S$ I4, I07.)

\section{§ 26. (g) To Do All Things Necessary.}

A corporation organized for some specified purpose has the legal right to do all proper things necessary to carry out that purpose, as, for instance, a corporation organized to build and operate a factory would without special authorization thereto have the right to buy and hold the real estate required for the erection of its plant.

In modern charters it is customary to specify many purposes and to amplify each to the utmost extent. Most of the powers usually specified would be included and secured without mention, as being incident to the main purpose or purposes.

\section{§ 27. Charter Powers-Special.}

The special powers of a corporation are those specifically mentioned in its charter which, if not so mentioned, it would not possess. The usual purposes with their customary extensive amplifications are included among these, but in most states the law allows many further powers that add much to the value of the corporate system. 
Among these may be mentioned the varied provisions as to the issue of preferred and other special stocks, the system of cumulative voting, the power to hold stock of other corporations and the like. Also restrictions of various kinds may be embodied in the charter, such as limitations on salaries to be paid officers, or restrictions on the power to mortgage the corporate property or to contract indebtedness generally. (See $\S$ I II, II5, I39-I4I.)

As a rule special powers may only be secured when expressly allowed by the statute law, and in the different states the laws vary widely in respect to the special powers permitted. In some states certain powers which are usually special privileges have been conferred by statute, so that all corporations enjoy them whether mentioned in the charter or otherwise. For instance, in New Jersey any corporation may acquire the stock of other corporations, and in Pennsylvania, Illinois, California and some other states cumulative voting at all corporate elections is prescribed by constitutional provision.

\section{§ 28. Things Ultra Vires.}

An individual or firm may do anything not forbidden by the law. A corporation, as a creature of the law, may only do those things expressly permitted to it under the law. All other things are beyond its powers, or in legal parlance, ultra vires. Contracts involving matters ultra vires can not be enforced by the corporation, though if the other parties to such a con- 
tract have performed their part, the contract may be enforced against the corporation-that is this latter can not evade its obligations by the plea of ultra vires. Directors and officers may make themselves personally liable for involving the corporation in transactions of this nature.

It must be said, however, that such exceedingly broad powers are now allowable under the laws and are so generally claimed by modern charters that the doctrine of ultra vires has not the importance it once had. Also, in a private business corporation without creditors almost any legitimate business transaction, whether authorized by the letter of the charter or not, may be undertaken without risk of interference from the law, if it has the assent of every stockholder.

\section{$\S 29 . \quad$ Amendment of Charter.}

Any corporate right or privilege that might have been secured by inclusion in the original charter of a corporation may, in most of the states, be secured by charter amendment, and such amendment may be made at any time, even before the organization of the corporation is completed.

Charter amendments are either the result of a too hasty preparation of the charter, or otherwise of changed conditions. At all times they involve both trouble and expense. When desired, they must in like manner with the original charter be secured either by means of a legislative act or by following the course prescribed by general laws. 
As soon as a charter amendment has been allowed by the state authorities, its provisions become to all legal intents, part of the original charter, and as permanently binding on the corporation. The charter amendment and the original charter then together constitute the working charter of the corporation, the amendment taking precedence of and modifying the original charter in all points of difference.

The procedure for the amendment of the charter is prescribed by the statute law and varies in almost every state. In some few states the procedure varies with the nature of the amendment, as in New York, where application must be made to designated courts if the name of the corporation is to be changed, while to change the number of directors, application must be made to the state authorities.

As a preliminary step, amendments of the charter usually require the due and formal assent of at least two-thirds of the outstanding stock of the corporation. The amendment so authorized is then as a rule filed in the same offices and with the same formalities as the original charter, becoming effective as soon as allowed and filed. 


\section{CHAPTER IV.}

\section{BY-LAWS.}

\section{§ 30. Definition.}

By-laws are the more permanent rules of corporate action as distinguished from motions and resolutions, these latter usually applying only to particular occasions and special matters.

A corporation is controlled ( $\mathrm{I}$ ) by the corporation laws of the state in which it is domiciled, (2) by the provisions of its charter and (3) by its by-laws, these three ranking in the order given as to authority. Hence all by-laws must be in harmony with the statutes of the state and also with the provisions of the charter of the particular corporation. Any by-law that does not accord with these higher authorities is void and of no effect.

By-laws are enacted by the stockholders and by them alone, unless, by statute, by charter provision or by action of the stockholders themselves, such power has been delegated in greater or less degree to the directors of the corporation. (See $\S \S 3$ I, 72, 94; also Form I3.) 


\section{$\S 3$ I. Adoption.}

There is usually no law, save the law of necessity, compelling a new corporation to adopt by-laws. Its operation without by-laws would, however, be practically impossible-so much so that the law confers the power to adopt by-laws and takes it for granted that this right will be exercised by the corporation.

It is true that when the incorporators meet for the organization of a corporation they already have the provisions of the state statutes and of their charter for the corporate guidance. These control as far as they apply, but, alone, they are incomplete and utterly inadequate and the by-laws must be added to provide for the many details of organization, administration and business routine yet to be covered.

The by-laws also usually include a systematic statement of the more important provisions of the charter and of the state law applicable to corporations. This is done in order to provide a convenient and accessible memorandum of these provisions. Without this they might be overlooked or forgotten.

A reasonably complete set of by-laws is usually adopted by the stockholders at their first meeting, and these by-laws are added to, amended or repealed from time to time thereafter as may be necessary.

In those states where power to make by-laws may be delegated to the directors, the privilege is very generally exercised. Such delegation of power ranges from the mere right to make by-laws in conformity with those adopted by the stockholders up to the wide 
and unrestricted power to make and alter by-laws at will. This latter power may be conferred by proper charter provision in New Jersey and some other states and is not unusual among the larger industrial combinations.

Save when the directors are empowered thereto, the by-laws may only be added to or otherwise modified by formal action of the stockholders in duly assembled meeting. In the larger corporations with their numerous and widely scattered stockholders, such meetings are necessarily a matter of time and difficulty, and it is desirable that wide power over the by-laws be given the directors to permit proper freedom of action under unforeseen circumstances. In the smaller corporations, however, such power should be granted with caution, if at all, as it practically results in divesting the stockholders of all power of control, removing the usual restrictions upon the actions of the directors, leaving the property and affairs of the corporation unreservedly in the hands of these latter and radically altering the whole corporate scheme. (See $\S 72$.

By-laws should be carefully drawn, properly adopted and accurately recorded in the minute book of the corporation. (See $\S \mathrm{I} 22$; also Form I4.) They should fully provide for all the important details of corporate procedure, such as the issuance and transfer of stock, the meetings of stockholders and directors, the election of directors and officers, the respective duties and responsibilities devolving upon these, and 
the care and management of the corporate property and finance. They should also include the more important provisions of the charter and of the statute law as far as applicable.

The by-laws of the corporation should be adapted to its particular needs. It is obvious that a small corporation with most of its stockholders at hand and with its officers and directors engaged personally in its business, does not require the comprehensive by-laws desirable for the great industrial corporations with thousands of stockholders widely scattered over the country and operating plants in half a dozen different states. It may be said generally that the by-laws should be clear, simple and direct and sufficiently complete to efficiently serve the purpose of the particular corporation. (See $\S \mathrm{I22}$; also Form I3.)

\section{§ 32. Amendment.}

The by-laws usually prescribe the method of their repeal or amendment. Unless otherwise provided by statute, charter or by proper provision of the by-laws themselves, these by-laws may always be repealed or amended, either in whole or in part, by a majority vote of a quorum of stockholders at any regular meeting, or at any special meeting duly called for that purpose. The directors have no power to repeal or amend by-laws under any circumstances unless such power is expressly given them by the laws of the state of incorporation, by the charter of the corporation or by its by-laws. 
of the by-laws, and disregard of their provisions are much more frequent and are more properly within the scope of corporate regulations.

Direct penalties for the violation or non-observance of by-laws are sometimes provided. These usually take the form of fines, but such penalties are, as a rule, unsatisfactory and very difficult of enforcement. In practice the smaller infractions and omissions on the part of directors and officers are usually passed over, or their too frequent recurrence prevented by the substitution of more reliable officials at the next election. The more serious violations bring their own penalties in the legal liabilities and entanglements that necessarily follow. For instance, a special meeting called without proper formalities is illegal and its action void. Contracts entered into without proper authorization may be summarily set aside. Corporate action taken in disregard of by-law provisions is for that reason not only illegal but may at times involve the directors and officers concerned in personal liabilities.

In this general connection it is to be noted that a corporation has no power to expel a stockholder, nor to deprive him of his rights of membership no matter what his offence. Any such penalties, if imposed, can not be enforced. 


\section{CHAPTER V.}

\section{STOCK.}

\section{§ 34. Capital Stock.}

The capitalization or capital stock of a corporation is the nominal capital authorized by its charter, $i$. e., the amount of stock as fixed by its charter which the corporation is empowered to issue. As shown later this may be the same or may be entirely different from its actual cash or property capital.

For the sake of accuracy and convenience in expressing the interests of the stockholders in the capital stock, and in the corporate property and business which this capital stock represents, it is regarded as divided into equal shares, termed "shares of stock." When by purchase or otherwise a person acquires an interest in the capital stock, he becomes a stockholder in the corporation, and his interest is expressed in these shares of stock.

Certificates of stock are issued to stockholders evidencing the number of shares which they own. These certificates of stock are popularly, though incorrectly, referred to as "stock." The interest they represent 
in the corporation is also, and correctly, designated "stock." (See § 42.)

The par, or face value of shares of stock is fixed by the charter of the particular corporation, and, unless expressly limited by statute, is placed at any amount desired by the incorporators. One hundred dollars is the most common par value of shares. In mining companies one dollar is a common par value, adopted with a view to impressive offerings and the reception of smaller subscriptions than could be taken with larger shares. In close corporations, or where a general sale is not desired, the face value of the share will sometimes be fixed at $\$ 500$ or even $\$$ I000. Shares are not ordinarily issued in fractional parts, but only in amounts of one or more whole shares. (See § I05.)

As the holdings of the stockholders of a corporation are expressed in shares, it follows that the number of shares owned by any individual gives an accurate measure of his interest in the corporation. For instance, if a man owns ten shares of the par value of $\$ 100$ each in a corporation with a capitalization of $\$ 10,000$, all of which is issued, he owns a total stock interest of $\$ \mathrm{I}, \mathrm{OOO}$, or one-tenth of the entire outstanding capital stock, and therefore has an undivided onetenth interest in the entire corporate property and business.

The interest of a stockholder in his corporation is always an undivided interest, $i$. $e$., no particular part of the property, or the business, or the capital stock 
belongs to the particular stockholder, but he owns his proportion of all these. If the corporation, from insolvency or other reason, were liquidated, any property remaining to the stockholders, or its proceeds, would be divided among them in the proportion of their stock holdings. In that event the undivided condition of their interest would terminate, but so would the corporation. As long as any corporate property exists their interests are in the undivided common property.

It may be noted that the par value and the actual value of a share of stock may be very different. A hundred dollar share of stock in a prosperous corporation will frequently be worth several times that amount, while in an unsuccessful corporation it may be worth little or nothing. In either case the par value remains the same. (See $\S 35$.)

Stock certificates are issued as a convenient evidence of the stockholders' interests in a corporation, and every stockholder whose stock is paid for has a right to such a certificate. These certificates state the number of shares owned, their par value, and usually any other material facts affecting the stock in question, as, for instance, if such be the fact, that it is full-paid, or that it is preferred stock. These certificates of stock are signed by the president and secretary, or president and treasurer of the corporation and are sealed with the corporate seal. When properly issued, they are conclusive evidence of the ownership of the stock represented by them. 
The stock certificate, as already stated, is merely the evidence of ownership of stock and is not the stock itself. The stock of a corporation usually exists, and may be bought and sold by proper entries on the corporate books, before stock certificates are issued at all. (See $\S \S 42,90,9 \mathrm{I}$; also Forms 6o-62.)

Each share of stock usually entitles the owner of record (See $\S 42$ ) to one vote in all proceedings of the stockholders, whether assembled in annual or special meeting. In most states by proper charter provision the voting power of stock may be restricted, or stock may be issued without the voting power. Preferred stock is very frequently so issued. Unless expressly denied or restricted by proper provision, all stock has the usual voting power and this right may be exercised by the owner of record in person, or, usually, by proxy. (See $\S \S 42,56$.)

\section{§ 35. Capital Stock vs. Capital.}

The "capital stock" or capitalization of a corporation should be very clearly distinguished from lits "capital."

The capital stock is the total amount of stock the corporation is authorized by its charter to issue. This amount is fixed in the first place by the parties organizing the corporation-who are termed the incorporators-and, once accepted and authorized by the State, may only be changed by formal amendment of the charter.

The capital, on the other hand, is the actual amount 
of property owned by the corporation,- that is, its assets. It is obvious that the value of these assets is liable to change with the fluctuations of the business or from other causes. The capital stock of the corporation and its capital, therefore, even though equal at first, may and frequently do differ greatly in amount. For instance, the capital stock of the Chemical Bank of New York City is $\$ 3,000,000$ while its capital is over $\$ 7,500,000$.

In conservative incorporations the capitalization usually corresponds with the initial capital. That is, for every dollar of stock the corporation issues at the time of its formation, it receives a dollar in cash or property. Later this relation will vary, the capital stock remaining the same but the capital increasing or diminishing with the fluctuations of the business.

In corporations of a speculative nature, as well as in some others, the capital stock is usually and intentionally fixed at an excessive figure. This is done in order that the stock may be sold at prices far below its apparent value, or in the expectation that the future earnings will support and justify the capitalization. In some cases capitalizations are increased far beyond the value of the corporate property for the purpose of concealing the profits actually earned by the particular corporation. Companies with these excessive capitalizations are said to be over-capitalized, and when this over-capitalization is intentional, the stock is said to be watered. (See §37.)

Each share of stock issued by a corporation repre- 
sents both the undivided ownership of its proportion of the assets and the right to its proportion of all dividends declared. The selling price of stock therefore is largely governed by these two factors, fluctuating according to the amount of capital and the rate of dividend. Thus when the capital stock of the Chemical Bank was $\$ 300,000$, its assets over $\$ 7,500,000$, and its annual dividends $\mathrm{I}_{5} \mathrm{O}$ per cent., its shares of the nominal or face value of $\$$ IOO sold at over $\$ 4,000$. Now with capital stock increased to $\$ 3,000,000$, its assets practically unchanged and the aggregate amount of its dividends the same-I 5 per cent. annually on the increased capitalization-its stock sells at approximately $\$ 425$ for each \$IOo share.

\section{§ 36. Unissued and Issued Stock.}

Unissued stock is in itself a nullity. Until it is issued it represents nothing. It is not an asset of the company but is merely an unexercised right to issue stock when and as subscriptions for it can be obtained.

Unissued stock usually represents excess capitalization. For instance a corporation organized to take over property worth $\$ 20,000$ might perhaps be capitalized at $\$ 25$,000 with the idea of selling the excess stock to raise working capital. Or perhaps a corporation will be capitalized with a view to its future needs at $\$ 100,000$, when but $\$ 50,000$ will meet all immediate requirements. This $\$ 50,000$ alone is then issued. The difference of $\$ 50,000$ is unissued stock entirely without value except for the power it gives 
of issuing this additional stock at any time it may be necessary without the formalities that would otherwise be required.

Issued and outstanding stock is that stock which has been issued for cash, property, labor, services or other values, or which has been subscribed for and the subscriptions accepted by the company. The actual certificates by which this stock is represented may not have been issued, but as soon as a purchase is duly consummated or a subscription properly accepted, the stock affected is issued stock, and the subscribers or purchasers are stockholders of the company. Should a subscription then be canceled by mutual consent of the interested parties, or by due procedure of the directors of the corporation, the stock affected would resume its character of unissued stock. Certificates for stock should not be issued to the purchasers until the corporation has received the full agreed price.

Sometimes stock issued and paid for in full will be regained by the corporation by direct purchase, by gift or by other means. Such stock is not thereby retired, nor does it become again unissued stock, but is held as "treasury stock," and may be issued again as full-paid stock at less than the original price without involving the purchaser in any liability. (See § 40.)

\section{§ 37. Full-Paid Stock.}

In most of the states payment for stock may be made in anything of value. If the corporation has received the full face value for issued stock in cash or 
in any other permitted form of payment, such stock is termed full-paid, and its certificates should be marked "Full-Paid" in order to indicate this fact. After stock has once been issued for full value, it may be sold at less than par without involving the purchaser in any liability for the difference.

If the corporation has not received the full face value for issued stock, the stock is but partly paid, and the purchaser of such stock may usually be held liable for the amount necessary to render the stock in his possession full-paid. This liability may be enforced either by the corporation, or, in event of its insolvency, by any creditor of the corporation.

It is to be noted, however, that if the corporation has agreed to accept less than the face value of stock in full payment, it is thereby estopped from collecting the deficiency, though the rights of creditors would not be affected by such agreement. Nor even if the corporation entered into such an agreement and issued certificates marked "Full-Paid" for stock sold thereunder, would a creditor be estopped from collecting the deficiency if the stock were in the hands of the original purchaser and the corporation were itself insolvent. If, however, such certificates had passed into the hands of innocent purchasers, both the corporation and its creditors would be estopped from any further exactions no matter how small the price originally paid for such stock.

Watered stock is stock for which the corporation has not received full payment in cash, services or prop- 
erty. Generally the term is applied to any stock for which the corporation has not received an equivalent in assets. Stock is said to be more or less watered according to the amount of real value it represents. Watered stock is usually created by the issuance of stock in payment for property or services which have been overvalued; sometimes also it is created by the issue of stock insufficiently supported by the corporate property, as for instance, in cases of unwarranted stock dividends.

\section{$\S 38$. Common Stock.}

Common stock is the general or ordinary stock of a corporation with neither special privileges nor restrictions. If any portion of the stock is given special privileges or restrictions, that portion is thereby removed from the class of common stock and the remainder is alone common stock. Any statements made concerning stock are usually understood to apply to the common stock, unless some other class or classes are specified.

\section{§ 39. Preferred Stock.}

Preferred stock, as the term is usually employed, is that which has some preference as to dividends or assets over other stock of the same corporation. This preference is usually secured to it by special provisions in the certificate of incorporation, though in some states this may be done by by-law provision.

Preferred stock may be either cumulative or non- 
cumulative as to dividends. If the latter, it must receive its preferred dividend for the current year before any dividend is paid the common stock, but if in any year its dividend fails or is only partly paid it loses the unpaid amount. The dividends of a cumulative preferred stock are, on the other hand, a charge against the profits of the company, accumulating in case of failure from year to year until paid, and taking precedence over any claims of the common stock. If its dividends are not paid in any year, or years, or are but partially paid, the amounts unpaid go over, or cumulate, and must be satisfied before the common stock receives anything.)

Cumulative preferred stock is sometimes called guaranteed stock, but this is a misnomer as its dividends are not guaranteed and are not payable unless profits are earned. The better use of the term "guaranteed" is to designate stock of one corporation upon which the dividend payments have been guaranteed by another corporation,-an arrangement common among railroad companies.

It is usually provided that preferred dividends shall be paid in full before the common stock receives any dividend. If there are further profits after the preference dividends are paid, it is sometimes provided that the preferred stock shall share equally in these with the common stock. More often-and always, unless otherwise expressly provided-after the preferred dividends are paid in any year, the common stock re- 
ceives an equal dividend if the profits are sufficient, and both kinds of stock then share alike in any further dividends declared in that year. At times, however, the preferred stock receives its preferred dividend, but does not participate at all in any further dividends of that year.

In some states it is provided by statute that preferred dividends shall not exceed eight per cent. Sometimes the charter provides that preferred stock may be redeemed out of the profits of the company after a certain number of years. It is often provided that in case of dissolution preferred stock shall be satisfied out of any assets of the company before the common stock receives anything. If this provision is not made, either by statute or by charter, the preferred stock in any liquidation of the corporation would first receive any dividends then due, but thereafter would fare exactly as does the common stock.

It is to be noted that preferred dividends may only be paid from profits. If there are no profits, or if the profits are needed for purposes of the business, preferred stock either receives no dividend, or if cumulative, its dividend passes over until profits are made. Unlike a bond, it is not a debt or liability of the corporation. Its owners are stockholders and not creditors, and failure of dividends ordinarily gives no cause of action against the company or its directors. For this reason preferred stock when available is usually considered a better means for raising money than an issue of bonds. (See $\S 89$; also Form 5.) 


\section{$\S 40$. Treasury Stock.}

Treasury stock, in the better use of the term, is stock which has been issued for value and has by gift or purchase come back into the possession of the company. It may be held in the name of the treasurer, of a trustee, or of the company itself. For bookkeeping purposes it is accounted an asset of the company. It differs from unissued stock in the fact that it may be sold below par without involving the purchaser in any liability for the unpaid balance. So long as the treasury stock is held by the company it can neither vote nor draw dividends.

Treasury stock is most commonly found in those numerous cases in which corporations are organized to take over and exploit a mine, an invention, or other speculative venture. The owners of the property to be taken over assign this property in exchange for the entire capital stock of the corporation as soon as this latter is organized. The stock is thereby supposedly full-paid and its holders are not liable to either the corporation or its creditors. In order to provide a means of raising funds for the otherwise impecunious corporation, the holders of this full-paid stock donate back to the corporation, or to some trustee for the corporation, a certain proportion of their stock. This stock, being full-paid, may be sold by the corporation for whatever it will bring, and the fact that it is sold below par does not impose any liability on the purchaser. This is the end desired.

The term "treasury stock" is sometimes loosely and 
inaptly applied to unissued stock and even to stock subscribed for but as yet unpaid. Unissued stock represents nothing but the unexercised right of issue, and its designation as treasury stock is inaccurate and misleading.

\section{§ 4I. Acceptance of Subscriptions.}

Formerly before a corporation was organized it was customary to circulate lists and secure subscriptions to its stock. (See Forms I-3.) The plan is still occasionally pursued. Under the form of subscription list usually employed in such cases the subscriptions must be accepted by the corporation before they become binding on either side. Until this is done the subscriber can not compel acceptance of his subscription, nor can the corporation prevent the subscriber from withdrawing his subscription if he sees fit. It is merely a proposition continuing until either accepted or withdrawn. As soon as accepted, however, it becomes a binding contract between the corporation and the subscriber, and the latter, by this acceptance, becomes a stockholder of the corporation. (See $\S 47$.$) If there are any outstanding stock subscrip-$ tions, they are usually accepted by the board at its first meeting.

The subscriptions of the incorporators do not require this formal acceptance by the corporation to become legally effective, the allowance of the charter by the state authorities acting as an acceptance of their charter subscriptions. The incorporators are there- 
fore stockholders upon the allowance of the charter and are thereby qualified to act in the organization meetings.

Subscriptions after organization must also be accepted before they become binding upon either the subscriber or the corporation, and until this acceptance the subscriber is not a stockholder of the corporation.

\section{§42. Certificates of Stock.}

A duly issued certificate of stock is a formal instrument under the corporate seal, signed by the authorized corporate officials and certifying that the party named therein is the owner of a specified number of shares of stock in the corporation issuing the certificate. When the owner sells this stock he effects the equitable transfer of title by the assignment of his certificate, though he is still the owner of record (See $\S 47)$ until the transfer is recorded upon the books of the corporation.

Each holder of stock for which the corporation has been paid in full, or for which it has been paid the agreed price, is entitled to receive a stock certificate signed by the president and the treasurer, or president and secretary, and sealed with the corporate seal. (See $\S 89$. ) This certificate states that the party named is the owner of so many shares of the company's stock, full-paid and non-assessable. This certificate is not the stock, though colloquially so termed, any more than a deed is the land it transfers. It is merely evidence of the ownership of stock, in such 
form as renders the transfer of the stock from hand to hand a simple matter.

A stockholder whose stock has been paid for has a right to a certificate because he is already a stockholder. The certificate is merely a convenient evidence of the fact. It does not of itself constitute him a stockholder, or, except in the matter of convenience, affect his ownership of his stock in any way. It might be lost or destroyed (See $\S 45$ ), but the party in whose name the stock stands on the books of the company is still a stockholder and entitled to the rights of a stockholder in spite of this loss. If his rights are questioned he may refer to the stock book and its record will control. (See $\S 46,9 \mathrm{r}$.)

Stock certificates are usually bound in a substantial volume, numbered from one up, with a stub for each certificate upon which is kept a record of the facts relative to the issue of that certificate. This book of certificates is usually kept by the secretary. (See § 89.)

The owner of a stock certificate may assign it and thereby authorize the proper officials of the corporation to transfer the stock it represents. The ownership of record is not, however, changed until such transfer has been made upon the books of the corporation. If the owner wishes he may surrender a certificate and have it reissued in two or more certificates of the aggregate value of the surrendered certificate. These certificates may be in his own name, or in the name of others as he may direct. 
The officials to sign stock certificates are in some states designated by the statutes. Where this is not the case they are usually prescribed by the by-laws.

\section{$\S 43$. Issuance of Certificates.}

When the corporation is organized the stock certificates are in the hands of the secretary, ready to be issued to the rightful owners, or to the parties designated by them. It may be that preliminary subscriptions have been taken and the stock is to be issued to these subscribers, or the company may have been organized to take over property, and, under the conditions of exchange, all the stock of the company is to be issued in payment for this property, or subscriptions may be offered at the time. In any case the procedure as to the actual issuing of the certificates is much the same.

Usually when stock is issued for property, the entire amount of this stock is included in the one first certificate. If, as is generally the case, the stock is to be distributed among a number of persons, this original certificate is duly endorsed by the person in whose name it stands and is then turned back to the secretary with instructions for its reissue in such names and in certificatęs of such size as may have been agreed upon.

Instead of this arrangement, on written order of the party transferring the property to the corporation, the stock is sometimes issued directly to the parties in interest, or, in accordance with their instructions, 
in a number of certificates, the total of the shares represented by these certificates equalling the full amount of stock to be issued. There is no legal objection to the plan, though the first arrangement is somewhat simpler.

If preliminary subscriptions have been taken, and payment has been made, or is proffered, or if subscriptions are offered at the time, the stock is issued in accordance with the instructions of these subscribers. The officers of the corporation must be sure that their instructions come from the proper parties, but beyond this have no concern as to the names in which these certificates are made out, or as to the equitable ownership of the stock involved.

When stock certificates are to be issued the secretary fills out the blank certificates in accordance with the requirements. These incomplete certificates are then turned over to the proper officials for signature. These do not affix the corporate signature but merely their respective official signatures. (See Forms 4, 5, 47.) When signed, the secretary seals the certificates with the corporate seal, enters all the important data concerning each certificate upon its stub, and the certificates are ready for issue. (See Forms 4, 5.) If the recipient is at hand he is required to sign the receipt upon the stub of the certificate at the time delivery is made. If he is at a distance a receipt is usually mailed with the certificate, and, when signed and returned, is pasted or otherwise attached to the stub of its certificate. 
When transfer agents and registrars are employed the stock certificates pass through their hands before issue, and usually these agents take entire charge of the matter.

\section{§ 44. Transfers of Stock.}

For convenience in transferring stock, each certificate bears upon the reverse side a blank form of assignment (See Form 6) which when properly filled out, or signed in blank and duly delivered, transfers the ownership of the stock represented by that certificate. When this form is filled out in its entirety, the ownership of the stock passes to the party named in the assignment. If, however, the form is signed in blank, $i$. e., with the name of the assignee omitted, the signature being duly witnessed, the certificate may be passed from hand to hand or used as collateral, without further endorsement or formality, the equitable ownership of the stock following the certificate. The ownership of record, however, including the right to vote and share in dividends, remains with the original holder until the transfer is made upon the books of the corporation. (See $\S \S 47,92$.) For this reason when stock is purchased, the transfer should be made upon the books of the company without delay, unless it is designed to transfer the certificate to some one else very shortly, or unless the stock is by intention to be left in the name of the original owner.

If the holder of a certificate endorsed in blank wishes to make himself a stockholder of record, he 
writes his name in the proper place in the blank form and also enters either the name of the secretary of the company, or his own name or the name of some other suitable person as attorney to make the transfer on the books of the company. (See Forms 6, 7.) This attorney, so designated, makes the transfer on the books of the company (See Forms 6I, 62), surrenders the old certificates for cancellation, and the transferee thereupon becomes a stockholder of record, entitled to vote and to receive dividends. $\mathrm{He}$ is also entitled to a new stock certificate or certificates, which he usually receives forthwith. (See $\S 48$.) The secretary upon receiving the surrendered certificate cancels it, attaches it to its stub, makes the proper entry on this stub and prepares the new certificate for issue.

When a transfer of stock is duly entered on the books of the company and a new certificate has been issued in the name of the party entitled thereto, such issue by the company acts as a guarantee of title, and it is not necessary for a prospective purchaser to investigate further than to make sure that the certificate is genuine and is properly in the hands of the holder.

\section{§ 45. Lost Certificates.}

A stockholder's rights are not affected by the loss or destruction of his stock certificate. (See $\S 42$.) Nevertheless its absence may involve much inconvenience, more particularly if the stock is to be sold, and the stockholder usually wishes a duplicate issued. 
This is within the province of the directors, subject, however, to any by-law provision which may apply. Usually the by-laws provide that a bond must be required before a duplicate certificate is issued and this takes the matter out of the discretion of the board.

In the absence of by-law provisions restraining them the directors may, if they deem such proceeding advisable, order a new certificate issued in the place of a lost one. Inasmuch, however, as the corporation might be held responsible and lose the value of the stock if the lost certificate turned up in the hands of an innocent holder, the board usually will not order the issue of a duplicate certificate unless a proper bond of indemnity is given the company. (See Form 75.) At times the board will not even do this, but will decline to act until ordered so to do by a court having jurisdiction. Such an order relieves the directors of any responsibility in the matter and the duplicate certificate then issues as a matter of course. If the lost certificate has been actually destroyed, as by fire, and the fact is proven beyond all doubt, the board might safely order the issue of a new certificate without requiring bond, if the by-laws permit.

If a certificate is lost the secretary of the company should be notified promptly, as otherwise the stock certificate might be presented under circumstances which would justify him in making any desired transfer. After notification he would make such a transfer at his peril. 
$\S 46$. Stock and Transfer Books.

Corporations should, and, in many states, must * keep a stock book or stock ledger showing who are stockholders, their addresses, when they became stockholders and how many shares they hold. (See Form 6o.) In some states the stock book must be kept open at all times during business hours for the inspection of stockholders and judgment creditors of the corporation. The stock book is the final authority as to who are the stockholders of the company entitled to vote and share in the dividends. Any statutory requirements should be fully observed. (See § 9I.)

A book of blank forms for the transfer of stock, known as the transfer book, is required by law in some states and is commonly kept by the larger corporations as a convenient form of record. (See $\S 90$; also Forms 6r, 62.) 
CHAPTER VI.

\section{STOCKHOLDERS AND THEIR MEETINGS.}

\section{$\S 47$. What Constitutes a Stockholder.}

The stockholders of a corporation are those who actually hold its stock, or who have subscribed for its stock and have had their subscriptions duly accepted by the corporation. A "stockholder of record" is one whose ownership of stock is duly recorded upon the books of the corporation.

At the time the corporate charter is granted, the incorporators are the only stockholders, the allowance of the charter having the effect of an acceptance of their subscriptions by the corporation. Any other subscribers, whether prior to incorporation or otherwise, must await the acceptance of their subscriptions by the company before they become stockholders, or are entitled to act as such.

The mere acceptance of their subscriptions constitutes the subscribers stockholders of the corporation. Neither payment of the amount subscribed, nor the issuance of stock certificates is necessary to the establishment of their status. If they fail to pay their sub- 
scriptions, they have no right to stock certificates and their general rights as stockholders may be forfeited, but until this is done by due proceeding, they are stockholders, entitled to be recorded as such upon the books of the corporation and thereafter to vote and to exercise the other rights incident to membership in the corporation.

When outstanding stock is purchased and the certificate is transferred to the purchaser by endorsement, the transfer must be entered on the books of the company before such purchaser becomes a stockholder of record, entitled to vote, to share in dividends, and to receive a certificate of stock in his own name. Until that time he is the equitable owner of the stock, but he has not entered into formal possession and is not known or recognized in any way as a stockholder.

\section{$\S 48$. Rights of Stockholders.}

The individual stockholder has but little part in the active management of the corporation. At the annual meeting each year he has the right to appear and vote in the election of directors and upon any amendment of the by-laws or other general matters brought before the meeting. The actual management then devolves upon the board he has helped to elect and he does not usually have any further direct concern with the affairs of the company until the next annual meeting.

The rights of holders of common stock may be stated as follows: 
I. To be notified of and to participate in all stockholders' meetings, in person or by proxy, and to cast one vote for each share of stock held.

2. To share, in proportion to the amount of stock owned, in all dividends declared on the common stock.

3. In event of the dissolution of the corporation to share in like proportion in any assets remaining after all the corporate debts and obligations have been paid.

4. To inspect the corporate books and accounts.

It should be said, however, that this last right has been so restricted by late decisions and legislation as to amount to little more than the right to inspect the list of holders of stock as shown by the stock ledger.

Holders of preferred stock have the same rights, except as these may have been extended or restricted by the conditions under which the stock was issued.

\section{$\S 49$. Powers of Stockholders.}

The powers of the stockholders may be summarized as follows:

I. Adoption or amendment of by-laws.

2. Election of directors.

3. Amendment of the charter.

4. Dissolution of the company.

5. Sale of the entire assets of the company.

6. The exercise of any specially conferred charter powers.

In matters like the amendment of the charter or the 
dissolution of the company, the power of the stockholders is usually regulated by statute and in most cases two-thirds of the stockholders must agree before effective action may be taken.

If any illegal action is about to be taken by the directors, or by the officers or the other stockholders of the company, the individual stockholder may appeal to the courts for such relief as is possible. Sometimes proposed action of the directors that is distasteful to the majority of the stockholders may be prevented by the calling of a special meeting of the stockholders, and the amendment of the by-laws thereat in accordance with the necessities of the case. This course is, however, somewhat radical and is not available in most cases of disagreement between stockholders and directors.

The board of directors is the sole managing and controlling authority of the corporation. The stockholders make the by-laws by which the directors are controlled, and elect the directors by whom the corporate affairs are conducted, but beyond this they do not interfere in any way with the transaction of the corporate business or the management of the corporate property. All this rests with the board. Nor can the stockholders act directly for the corporation. A contract signed by every stockholder would not be the contract of the corporation and would not bind the corporation, unless also signed by its proper officers, or otherwise formally accepted by its directors. 


\section{§ 50. Liabilities of Stockholders.}

A stockholder is liable to the company, or to its creditors, for any instalments remaining unpaid upon stock subscribed for by him. He may also be liable to creditors on any stock held by him, which is not fullpaid. (See § 37.) Should dividends be paid from capital, instead of from profits, stockholders are liable to corporate creditors for any amount so received by them.

The stockholders of New York corporations are personally liable for all debts due to laborers, servants or employees for services rendered the corporation. This is an unusual provision found in but few other states, and proceedings under it are infrequent. Stockholders of California corporations are liable for their proportion of any corporate debts even though their stock may have been paid in full. Unusual liabilities are also found in a few other states.

Also stockholders of national banks and of most state banks and trust companies are held liable in case of the insolvency of their institutions for an amount equal to their original subscriptions.

As a rule, however, in the ordinary business corporation the holder of full-paid stock is in no danger of losing anything more through corporate failure or involvement than the amount he has actually invested in his stock. That is, if the corporate business is an utter failure, the holder of full-paid stock will lose the money he paid for his stock, but can lose nothing more save by his own action or consent. (See $\S$ I2.) 


\section{§ 51. Meetings.}

In some few states the statutes provide that corporate action may be effected in certain stated cases by written assent thereto of all the stockholders or directors. Except when so provided by statute, corporate action may only be taken at meetings and in no other way. The written assent of all the stockholders is absolutely ineffective, nor can the directors act by signed agreement without a meeting.

In all matters where the procedure is not specifically prescribed by the by-laws the corporate meetingsboth of stockholders and of directors-are governed by the usual parliamentary law, which it is the duty of the president to enforce. Some particular manual of parliamentary law is frequently adopted to control in all cases not covered by the by-laws. Occasionally the by-laws prescribe the manual to be used.

\section{$\S 5$. Annual Meeting.}

The annual meeting is the only usual regular meeting of stockholders and is as a rule the one occasion on which the stockholders participate actively in the affairs of the company. It must be held in the state in which the company is incorporated, unless the laws of such state expressly provide otherwise, and is usually required to be held in the principal office of the company. (See $\S 96$.

At the annual meeting the directors for the ensuing year are elected, the reports of the officers are presented, any amendments to the by-laws may be sub- 
mitted and acted upon, and any affairs of the company requiring the action or attention of the stockholders may be presented for consideration. If any sweeping change in the business or policy of the company is desirable, it is usually authorized by action of the stockholders at this meeting. (See Forms 24, 25, $33,35$.

\section{$\S$ 53. Special Meetings.}

If action by the stockholders is necessary in the interim between the annual meetings, a special meeting must be assembled. Such special meeting of the stockholders is called by resolution of the directors, or by a call signed by the majority of the stockholders, or in any other way the by-laws may prescribe or permit. (See $\S 54$.) This call is followed by a notice to the stockholders, giving the necessary details of the meeting to be held. The method of calling special meetings and of notifying them to the stockholders, as well as the general procedure in connection with such meetings, is usually prescribed in the by-laws and must be carefully followed.

The call for a special meeting (Form 27), and also the notice issued pursuant to this call (See Form 28), must recite the three essentials, viz.; the time, place and purposes of the meeting called, and every stockholder must have due notification. No business except that specified in the call and notice may be legally transacted at a special meeting.

Where the stockholders are not too numerous, much 
time and trouble in assembling special meetings may often be saved by the stockholders uniting in a call and waiver of notice. (See Form 26.) If all will sign this, no further formality need be observed, and the meeting may be held forthwith. This is the usual procedure in the case of organization meetings which are, in fact, merely special meetings of the stockholders.

\section{§54. Notice of Meeting.}

A clear distinction must be made between the call for a meeting and the notice by which such meeting is actually assembled. Colloquially the two terms are often confused. The call is a formal request or demand from the president, or some proportion of the directors or stockholders as may be prescribed by the by-laws, for the assembling of the stockholders or directors for specified purpose in special meeting. It is preliminary to the notice and is the authority under which notice of a special meeting is sent out. Regular meetings are not called, except in so far as the provisions of the by-laws in regard thereto serve as a standing call. In sending out notices of regular meetings the secretary ordinarily acts under authority of these by-law provisions alone. Special meetings must, however, be formally called and this call when properly issued, authorizes the secretary to send out notice of the desired meeting. Notices of special meetings should always specify the authority under which they are issued.

(See Form 28.) 
The by-laws should provide very explicitly the manner in which notice of both special and annual meetings is to be given stockholders. Every stockholder is entitled to due notice of the time and place of meetings in which he is interested, and this notice should be given such reasonable time in advance of the meeting-usually five to ten days-as will enable him to attend conveniently.

The statutes in many of the states provide for notice of annual meetings by publication in some suitable newspaper of the vicinity. In a large city this is a very uncertain method and should be supplemented by notice sent by mail to the last known address of each stockholder. (See Form 25.)

If the by-laws specify the time and place of regular meetings, the neglect of the secretary to send out or publish the prescribed notice will not ordinarily invalidate the proceedings at such meeting. (See Form 24.) The proper notice should always be sent, particularly if important action is to be taken, but, unless the conditions are unusual, the by-law provisions are held to act as a sufficient notice of the time and place. A special meeting is, however, invalidated by failure of notice unless otherwise expressly agreed by every party entitled to notice. (See $\S 53$.)

Notices of regular meetings generally specify the purposes of the meetings they announce. This is not essential-unless matters of special importance are to be considered-but is customary. Notices of special meetings should always state the purposes of the meet- 
ings called and no business may be legally transacted at such meetings-save by consent of every stockholder of the corporation-unless it has been stated in the notice.

\section{§55. Quorum.}

The quorum, $i . e$. , the proportion of the outstanding stock which must be present to enable the transaction of business at a stockholders' meeting, should be prescribed in the by-laws. The usual provision requires the presence of a majority of the outstanding stock. When a quorum is present, a majority of this quorum has power to decide any question that is brought before the meeting.

If a quorum is not present at any meeting, the stockholders in attendance are not able to transact business, but they may adjourn from day to day, until a quorum is secured, and the meeting held. This saves the trouble, formality and possible delay of calling another meeting and is sometimes a very convenient procedure.

In the absence of statutory regulation, any desired proportion of the stock may be designated by the bylaws as a quorum for the transaction of business. For obvious reasons a quorum should usually require a majority of the outstanding stock. If there are no by-law, charter or statutory requirements as to the proportion of stock necessary to constitute a quorum, the common law rule prevails and the holders present 
-provided there are more than one-form a quorum capable of transacting business.

\section{\$ 56. Voting.}

Only stockholders of record (See $\$ 47$ ) are entitled to rote at anmual and special meetings of the stockholders. Each stockholder of record is entitled to one rote for each share of stock held in his name. In elections of directors this means that for each share of stock held the stockholder is entitled to cast one rote for each director to be elected, - that is, if five directors are to be elected he may cast one rote for each of these. Under the cumulative system of roting, which is designed to secure minority representation on the board, the stockholder still casts one vote for each director to be elected, but he may cast all five votes-if five directors are to be elected-for any one candidate or may distribute them among the five as he sees fit. (See \$S I12, I35.)

Voting at elections of directors is usually by ballot. (See Forms 69, 6ga.)

\section{\$ 57. Proxies.}

Any stockholder entitled to rote at a stockholders meeting may usually give a proxy, or-as it may otherwise and properly be termed-a power of attorney empowering some other party to attend at stockholders" meetings as his representative and rote upon his stock in his stead. If this right of substitution is not given by the statute law, it should be provided 
for in the by-laws. It is not a common law right and does not exist unless expressly given by some competent authority.

By means of proxies important meetings are often held with only a few persons present, enough stock being represented by proxies in the hands of those present to make up a quorum and enable a legal meeting to be held. The person holding a proxy is frequently himself designated the "proxy" of the person he represents.

In some states the life of proxies is regulated by statute, as in New York where a proxy must be executed not more than eleven months before it is used, in New Jersey where three years is the legal limit and in Maine, where a proxy must be executed within thirty days of the date of the meeting.

Proxies, unless the holder has himself some interest in the stock he represents, are revocable at any time, and this notwithstanding the fact that the terms of the particular proxy may state that it is irrevocable. The mere presence of the owner of stock at a meeting acts, if he so desires, as a revocation of proxies given by him for that meeting. A second proxy given while another proxy on the same stock is outstanding acts, when presented to the secretary, as a revocation of the first proxy.

A proxy may be so drawn if desired as to convey a limited right, such as to vote only on some special subject or in some particular way, or at some special meeting. A stockholder may, if he wish, give a 
proxy for a specified portion of his stock, reserving the right of representation on the balance to himself or conveying it to some one else by a second coexistent proxy.

A person holding a proxy, unless limited by the terms of the proxy itself, has every" right of participation in the meeting at which he acts that the stockholder would himself possess if personally present. (See Forms 16, 32-34.)

\section{$\S 58$. Election of Directors.}

The annual election of directors is the most important event in the corporate calendar, though in small corporations when there have been no material changes of stock during the year the election is frequently omitted, the old board merely holding over for another term. If all the stockholders acquiesce, there is no legal objection to this procedure.

Owing to the importance of the subject, many states have passed special laws regulating the election of directors. These usually provide that the election must be by ballot and must be conducted by inspectors of election appointed for the purpose. The bylaws should provide for all details relating to elections. (See $\S 56$; also Form I3, Art. I, Sec. 5.)

\section{$\S 59$. Officers of Meetings.}

In the smaller corporations the regular officers of the company usually act as the officers of stockholders' meetings. In the larger corporations the stockholders 
customarily have their own officers of meetings, who may or may not be the regular officers of the company.

If the stockholders are to have their own officers of meetings, the by-laws will usually, though not necessarily, so state and also provide for the election or appointment of these officers. In the absence of any by-law provision for officers of meetings, a meeting of stockholders should be called to order by some member present, and a president, or chairman, and a secretary, elected or appointed for the occasion.

If the regular officers of the corporation are to serve at stockholders' meetings, this should be prescribed by the by-laws, as otherwise they have no authority to so act. (For officers of directors' meetings see $\S 66$. 
CHAPTER VII.

\section{DIRECTORS AND THEIR MEETINGS.}

\section{$\S 60$. Status and Functions of Directors.}

The board of directors is the most important feature of the corporate organization. Elected by the stockholders, it has the entire management of the corporate affairs. In its turn the board elects the officers of the corporation, through whom it acts. It also employs such other agents and employees as may be necessary for the proper conduct of the corporate business.

The directors of a corporation are held to be its agents, and, in a measure, trustees for the stockholders. It is their duty to act with all proper care and diligence in looking after the affairs and property of the corporation, and they are responsible for its proper management.

Not infrequently the directors are styled "officers" of the company. This designation is legally correct but as it tends to produce confusion it is not employed in the present volume.

The directors are usually elected at the annual meet80 
ing of the stockholders to serve for the ensuing year. Should the annual meeting be omitted, or should the stockholders fail to elect a new board at the annual meeting, the directors then in office continue to serve until the election of their successors and this whether such continuance of their term is specified in the bylaws or not. Until the election of their successors, these "hold over" directors have every power that they possessed before the expiration of their elective term.

§6r. Number and Authority.

The number of directors composing the board is in many states fixed within certain limits by statute. In most of the states there must be at least three directors. The maximum number is not usually designated. For all ordinary corporations a small board is most convenient, and, as a rule, most effective. If the board is large the individual responsibility of the members is much diminished or lost, prompt effective action is practically impossible and at times it is even difficult to secure a quorum for the transaction of necessary business.

When the board is unwieldy or difficult to assemble, the actual administration of the corporate affairs is usually delegated to an executive committee composed of from three to five members. (See $\S 73$. ) By this device the prompt and effective action of a small body is secured for the actual direct management, while the board in which rests the nominal control-and 
the actual final authority-may be as large in size and as irregular in meeting as the conditions dictate. A large board is not infrequently necessary or very desirable in order that all interests may be represented, or that stockholders of special weight and influence may be included.

The board elects the corporate officers, appoints such other agents as may be necessary and has entire charge of the property, interests, business and transactions of the company. Unless with the express sanction of the stockholders its authority does not extend to radical action, such as the sale of the entire assets of the company, which is a virtual winding up of the corporate business, but does cover all ordinary corporate transactions. In these matters the directors have the widest discretion and are practically independent of the stockholders, except in so far as these latter control by means of charter or by-law provisions. To such provisions the directors are amenable.

The directors can only act collectively and in a regular meeting or in a duly assembled special meeting. A single director unless authorized thereto by resolution of the board, or specially empowered in some other way, has no standing of any kind in corporate matters above that of any other stockholder.

\section{$\S 62 . \quad$ Liabilities.}

Directors are held to be quasi trustees for the stockholders. As such, they are liable for any wrongdoing; also for any neglect that results in loss to the 
corporation. For instance, they are liable if they issue stock as full-paid which is not full-paid, or pay dividends out of the capital of the company when there are no profits, or otherwise abuse their power, or grossly mismanage the affairs of the company. In short, they have undertaken a trust, and they must conduct themselves in its administration as would careful business men in the management of their own private affairs.

In addition to this general liability, special laws have been enacted in many states, making directors liable criminally, as well as civilly, for certain acts, such as declaring illegal dividends, making loans to stockholders out of corporate funds, making false reports, etc.

As a trustee, a director must have no interest adverse to the interests of the company, and he should not involve himself personally in any contract or business in which the company is concerned unless the matter in hand is clearly to the advantage of the company. The courts scrutinize transactions of this kind closely and an objecting stockholder may have a contract between a director and the company set aside if he can show that undue influence has been used to secure such contract, or that it is not to the best interests of the company.

In many of the large corporations of the present day, the corporate operations are so extended and diversified that prohibition of contracts in which their directors are interested would seriously restrict the 
corporate business. For this reason the by-laws of these corporations frequently provide that corporate contracts in which the directors are interested, directly or otherwise, may be entered into under certain prescribed conditions. These usually provide that a majority of the directors or a majority of a quorum, outside the interested member or members, must vote for such contracts, or that they must be authorized by a certain prescribed number of directors who are not interested.

\section{§63. Qualifications.}

In most of the states the statutes require that directors shall be stockholders of the company; also, usually, that one member of the board shall be a resident of the state of incorporation. In some of the states the stockholding requirement may be waived by proper provision in the charter or by-laws. If directors are required to be stockholders, any director disposing of his stock thereby vacates his office, and the position he occupied is vacant and may be filled by the board without any formality beyond the election of his successor. One or more shares of stock are often given to a party desired as a director in order to qualify him for the position. Such directors are termed "dummy" directors. (See $\S \S$ I23, I47.)

In most, if not all of the states, married women may act as directors, as may, generally, any person capable of contracting. 


\section{§ 64. Vacancies.}

A board of directors may continue to act though there be vacancies, provided sufficient members remain and are present to make up a quorum. As a measure of safety, however, vacancies should be filled as they occur and authority to do this should be conferred on the board by the by-laws. The board does not possess this power unless it is specifically given.

Directors can not be removed, either by the other directors, or by the stockholders, unless such power of removal is expressly given by the certificate of incorporation, the by-laws, or the statutes of the state. Where directors may be removed for cause, charges of sufficient weight to justify the removal must be preferred, due notice must be given the accused person, and the charges must be substantiated before his position may be declared vacant.

\section{$\S 65$. Classification.}

In the larger corporations to avoid the possibility of sudden changes of policy that might result from a sweeping change in the personnel of the board, the directors are frequently divided into classes, differing only in the time of their election. The usual number of classes is three, and, after the first election, the directors of one of these classes are elected each year and hold over for three years. Under this arrangement, after the first election, only one-third the total number of directors is elected each year, and three years are required to make a complete change of the board. 
It is obvious that the plan completely prevents any sudden change in the composition of the board, unless by general consent and arrangement, and therefore insures stability in the management of the corporation. Such classification is not usual in the smaller corporations and would not as a rule be of any advantage to them.

\section{$\S 66$. Regular Meetings.}

The times and places for regular meetings of the directors are fixed by the by-laws. Monthly meetings are generally prescribed, but the frequency of such meetings will be determined entirely by the requirements of the particular corporation. In a small company one regular meeting a year may suffice. Should action of the board prove necessary in the interim, special meetings may be readily called, or be held by consent whenever the occasion arises. As a general rule directors must hold their meetings in the state of incorporation and these meetings are usually held in the principal office of the company. (See $\S 96$. ) They may be held elsewhere in the state if permitted by the by-laws, or without such permission, by unanimous consent of the members of the board. A meeting outside the state is not legal except where expressly permitted by the statutes of the state.

Directors can not give proxies to others to act for them at meetings of the board, but must be personally present if they wish to be represented.

The officers of the company are also the officers of 
the board and act as such at all board meetings. An exception to this general statement must be made as to some of the larger corporations in which a special presiding officer termed the chairman of the board is not uncommon.

\section{§67. Special Meetings.}

The by-laws should clearly prescribe the method by which special meetings of the board are to be called. Commonly it is provided that the president or two or more of the directors may call such meetings. Calls for special meetings must specify the time, the place and the business to be transacted, these details must be repeated in the notice, and no other business than that so specified may be transacted at that meeting. (See $\S 68$.)

If, however, all the directors meet or are present and consent, a special meeting may be held then and there, without call or notice of any kind, and in the absence of objection any proper business whatsoever may be transacted. Where the board is small and easily assembled such a "consent" meeting is convenient and entirely unobjectionable. As all are present and consent, every formality is thereby waived and no dispute as to the legality of such a meeting can arise later. The presence of all the directors at the meeting and their consent thereto should, however, be very clearly evidenced, either by proper entry in the minutes, or, better, by a written statement signed by all the directors. 
When this method can not be followed, a call and waiver of notice, signed by all the directors, makes it likewise possible to hold an immediate meeting without further notice. (See Form 30.) When neither of these methods is practicable, the formalities prescribed by the by-laws for the calling of special meetings should be closely followed. (See Form 3оa.)

\section{$\S 68$. Notice of Meetings.}

The members of the board are supposed to know when and where its regular meetings are held, and, even though notice be required by the by-laws, failure of notice will not invalidate the proceedings of such a meeting. Notices should, however, always be sent out, both to insure the attendance of the members of the board at the meeting, and to remove any possibility of dispute or trouble as to its proceedings. Usually such notices specify the important matters that are to come before the meeting.

With special meetings the case is quite different. Here due notice as to the time, place and purposes of the meeting is absolutely essential and if any director does not receive this notice he is not bound by the action of such special meeting and may have its proceedings set aside if he chooses to take the necessary steps. Therefore the directions of the by-laws should be followed to the letter both as to the call and notice of special meetings, and, whether required by the bylaws or otherwise, every notice should distinctly spe- 
cify the time and place of the meeting and the business to be considered thereat. (See Form 3r.)

As has been stated $(\S 67)$, notice of special meetings may be waived and the meeting held at any time and place and any business transacted thereat by agreement of all the directors.

\section{§69. Quorum.}

A majority of the board is usually necessary to constitute a quorum. This means a majority of the whole board, not a majority of some reduced membership caused by resignations or removals. A majority of the prescribed quorum decides the action of the board. Unless regulated by statute the charter or by-laws may prescribe the number necessary to form a quorum. To allow less than a majority of the board to constitute a quorum is not uncommon but is a measure of doubtful wisdom.

\section{$\S 70$. Election of Officers.}

The board can only act through officers and agents, who are elected or appointed by the board. Usually the election of officers is held at the first board meeting in each year after the new directors for the coming year have been themselves elected. This is so arranged in order that the new directors may elect their own officers and thereby secure an official staff in harmony with their views and policy. The usual executive officers are a president, vice-president, treasurer 
and secretary. Two offices may be held by the same person if the duties are not incompatible. (See $\S 75$.)

The directors have the right to fill any official vacancy occurring during the year. They have no right, however, to remove officers-except for cause-unless such power is expressly given them by the by-laws, the charter, or the laws of the state. In some few states broad rights of removal are given the directors by statute.

In case of any failure to elect officers at the appointed time the old officers hold over until their successors are elected. Until superseded these old officers have the same power to perform the duties of their respective offices that they enjoyed before the expiration of their term. If the board fail to elect officers at the appointed time, directors may, if they see fit, hold such election at the next regular board meeting, or at a special meeting called for the purpose.

\section{$\S 7$ I. Compensation of Directors.}

In the larger corporations it is generally provided that a director attending any meeting of the board shall receive a certain fee for his attendance. The amount of this fee is best fixed by the by-laws and ordinarily ranges from five to twenty dollars. If a director is absent from a meeting, his fee for that meeting is lost to him. Except for these fees directors do not usually receive compensation unless they 
perform some special service outside the ordinary duties of a director.

If the directors are to receive payment for their services, that fact should be explicitly stated in the by-laws. In the absence of any such provision the services of the directors are supposed to be given without charge.

\section{$\S 72$. Power to Pass By-Laws.}

Originally by-laws were passed by the stockholders alone, and one of the principal purposes of these by-laws was to define and limit the action of the directors and officers of the company. 'In the present day this has been modified in some of the states by statutes giving the directors more or less power over the by-laws. In some other states such power may be given the directors by suitable charter and by-law provisions.

Under the New Jersey laws it is possible to give the directors absolute power to make and alter the bylaws, and in the great corporations formed in that state for the purpose of combining industrial enterprises and for other large undertakings, such authority is usually conferred upon them. In New York the directors may neither repeal nor alter by-laws adopted by the stockholders, but are allowed to pass additional by-laws in harmony with those of the stockholders. The New York rule would seem to go as far in this direction as is safe for the ordinary corporation. (See $\S 3 \mathrm{I}$.) 


\section{$\S 73 . \quad$ Executive Committee.}

In the larger corporations the board of directors is generally composed of a number of members and these members are usually busy men living in different parts of the country and difficult to assemble. Many of them are on the board solely as representatives of special interests, or because of wealth or influence, and not because of peculiar fitness for the conduct of the corporate business. Under such conditions the board is not an effective instrument. Its slow, formal and uncertain operation is then advantageously replaced by the prompt and efficient action of a small, selected executive committee.

The membership of this committee is seldom less than three or more than five. Too large a committee would involve the very evils it was created to avoid. It must be composed of members of the board and this membership is supposed to be made up of those most competent to manage the corporate affairs. Usually for the interim between board meetings all the powers of the board are given to this committee.

The executive committee appointed with such powers is the real managing body of the corporation. It is subject to the instructions of the board, but this latter body as a rule merely supervises the work of the committee, acting only in those matters which are referred to it by the committee or which are of unusual importance. The power of the committee is generally defined by the charter or by-law provisions under which it exists. 
When the board of directors is small, an executive committee is not only unnecessary, but may become an actual menace to the interests of the corporation. In such cases the committee is apt to improperly monopolize the management of the corporation, the board being excluded from its rightful direction of the corporate affairs.

\section{§ 74. Finance Committee.}

In the larger corporations, in addition to an executive committee, a finance committee is often provided to supervise and direct the financial affairs of the company. For the interims between board meetings the scope, powers and authority of this committee in matters relating to the finances of the company are, as a rule, the same as those of the board. A finance committee is superfluous in the smaller corporations.

The finance and executive committees are permanent, or standing committees. Still other standing committees are found in some of the large corporations. 


\section{CHAPTER VIII.}

\section{OFFICERS.}

\section{$\S 75 . \quad$ Enumeration; Qualifications.}

The term "officer" is usually applied to those agents of the corporation who are elected or appointed by the board of directors as the direct executive representatives of the board and of the corporation. Technically the directors are themselves officers, but this application of the term is apt to cause confusion. (See $\S 60$. )

The necessary officers of the corporation are the president, secretary and treasurer. In the smaller corporations when the duties are compatible two of these offices are frequently held by one person. In the larger corporations the number of officers is increased by the addition of one or more vice-presidents, assistants for the secretary and treasurer, a managing director or general manager, an auditor and a counsel for the company. Sometimes also a chairman of the board and officials for the standing committees are added.

The officials named, are, for the most part, elective, 
and, with the occasional exception of the general manager and the assistant officers, report directly to the board or to the standing committees. All these are officers of the company while those lower in its service are ranked as agents and employees.

The annual election of officers usually follows closely the election of directors, being held as soon thereafter as the newly elected board can be properly assembled. This is done in order that the new directors may choose officials acceptable to them and in harmony with their views. (See $\S 70$.)

The president and vice-president, as presiding offcers of the board, should be chosen from its membership. Save as to these, the officers need not be selected from the board though the treasurer is frequently chosen from among the directors and the other officials are so selected when convenient. Financial standing or ability is a necessary qualification for the treasurership of the larger corporations. A knowledge of the duties of the position would seem to be a necessary qualification for all corporate officials, though other considerations frequently prevail.

\section{§ 76. Vacancies and Removals.}

The directors have power to fill any vacancies that may occur among the officials of the corporation, such interim appointments holding for the unexpired term. Officers can not be removed at the pleasure of the board unless the by-laws, charter or statute law gives the directors this power. The directors may, how- 
ever, remove an official for good cause without special authorization.

When the removal of an officer for cause is contemplated, charges should be made, the accused be notified of these charges and full opportunity be allowed him for a hearing. Should the removal be made without such procedure, or with it, but on insufficient grounds, both the corporation and the directors personally might be liable in damages.

\section{§ 77. Liabilities of Officers.}

Officers are liable generally for all damages resulting from their negligence or active wrong-doing in connection with official duties. In addition the laws of most states impose upon them special liabilities for various acts and omissions, such as the failure or refusal to allow proper inspection of the stock books of the company, the making of false reports or certifications, loaning corporate funds to stockholders, and other similar cases of neglect or malfeasance.

\section{$\S 78$. Compensation of Officers.}

Usually officers of a corporation are paid for their services and if necessary may collect such payment from the corporation by process of law. If, however, they stand in any relation to the corporation-such as that of a director or stockholder-that would justify the inference that they were to serve without compensation, and there is no by-law, resolution of the board, or other well-understood agreement for official sala- 
ries, they have, generally speaking, no claim to payment for their services. Nor in the absence of provision for compensation is it ordinarily allowable for the directors-unless with the consent of all the stockholders-to vote a salary or payment to a director or stockholder for services as an officer after such services have been rendered.

It is therefore advisable in all cases that the intention as to compensation of officers shall be clearly stated in the by-laws, - - either that officials shall serve without compensation, or with salaries specified in the by-laws or with such salaries as the board shall designate at the time of their election.

Occasionally such liberal salaries are paid to the corporate officials as to amount practically to a division of the corporate profits among them. In close corporations where all the stockholders are either officials or satisfactorily represented on the official staff this is at times a matter of agreement. Under such conditions the arrangement is legitimate and unobjectionable. Occasionally, however, the device is adopted in order to deprive the stockholders of profits which would otherwise and properly be received by them as dividends. Where any apprehension of such improper practices exists, the possibility should be prevented by by-law restrictions on salaries. (See $\S \S$ I I 5, I 39.)

\section{$\S 79$. Powers and Duties of Officers.}

The officers of the company carry out the instruc- 
tions of the board, and outside the routine duties assigned them by the by-laws, or by the statutes, have no independent powers or authority of any kind. The duties of officers should be clearly stated in the bylaws, but, if not, may be prescribed by the board within the general limits set by custom. The usual duties performed by the respective officials of the corporation are much the same in the different corporations, varying somewhat with the size of the corporation and the nature of its business.

It is to be noted, however, that outside of the few statutory duties prescribed in most states, such as making reports, filing statements, etc., the duties of the various officials are absolutely within the discretion of the stockholders, and may, by proper by-law provision, be fixed in accordance with their wishes. Occasionally this power is exercised so as to materially change the usual relative status of the different officials.

In the present chapter the powers and duties assigned the various officials are those customary in the ordinary corporation of moderate size.

\section{§ 80. The President.}

The president is the most important officer of the corporation. He presides over the meetings of the board, and, if authorized thereto by the by-laws, over the meetings of the stockholders. $\mathrm{He}$ can bind the corporation in most routine matters, and usually affixes the corporate signature to all important instru- 
ments requiring such signature. He must, however, be specially authorized by the board in order to bind the corporation in matters of unusual importance or outside the regular routine. (See $\S 98$.)

The president should exercise a general supervision over all the corporate business, and, as necessary or required, report to the board and to the stockholders as to the condition of the company's business.

The president is sometimes authorized to affix the corporate seal and is frequently required in connection with the treasurer to sign or countersign the corporate checks. $\mathrm{He}$ is also frequently given the same power to endorse negotiable paper and to endorse checks for deposit as is given the treasurer. $\mathrm{He}$ is 'also usually required with the treasurer or secretary to sign the certificates of stock.

\section{§ 8I. The Vice-President.}

Vice-presidents, designated and ranked as first, second, third and so on, are elected in accordance with the corporate needs. These in the order of precedence perform the duties of the president in the absence or disability of that official or in his refusal to serve. Also in the larger corporations special duties, or a portion of the president's usual duties, are assigned to one or more of the vice-presidents.

Frequently the number of vice-presidents is swelled merely to provide honorary positions for members of the board. In the smaller corporations, on the other hand, the position of vice-president is sometimes 
omitted entirely, its duties being assigned the treasurer, or the treasurer being elected as both vice-president and treasurer.

A vice-president may take the place of the president only in the absence, disability or refusal of this latter to act. At other times a vice-president has no more power to act for the president, or as president, than has any other officer of the corporation, and should he so act it would be ineffective and his action would not be binding 'on the corporation. Also the absence, or disability of the president must be real and his refusal to act must be a distinct refusal to fulfill the general duties of his position, before the vice-presidents are competent to perform his duties. In event of any question as to the competence of a vice-president to act the board of directors must judge.

\section{§ 82. The Secretary.}

The secretary's usual duties require him to keep a record of the proceedings of the stockholders and directors, to send out notices of meetings, to issue stock certificates, to keep the record of stock and stockholders, to notify officers of their election, to sign or countersign such corporate instruments as the board may direct, and to preserve and keep safely all such corporate instruments and records as do not pertain to the work of the treasurer, and are not otherwise assigned. (See $\S \S 8$-9I.)

The secretary usually has the custody of the seal and is required to attest it when it is affixed to any 
instrument requiring the formal corporate seal. (See $\S \S 97,98$; also Form 48.) Also the secretary is frequently required to sign certificates of stock with the president, though in some states, as New Jersey, he may not do so, the statutes requiring the signature of the president and treasurer.

The secretary is frequently given active duties in connection with the business of the corporation, but these have no necessary relation to the duties of his official position.

\section{§83. The Treasurer.}

The treasurer has charge of the funds and securities of the company. If these are of any considerable amount he should be required to give bond for the faithful performance of his duties and the due return of the cash and securities entrusted to him. (See Form 74.)

Usually the treasurer is directed by resolution of the board, though sometimes by by-law provision, to deposit the moneys of the company in the name of the company in some designated bank or other depositary. His checks are usually required to be countersigned by the president. He frequently has sole power to endorse negotiable paper and checks for collection or deposit.

The treasurer either acts as bookkeeper, or the bookkeeping. is done under his direction and he is supposed to maintain a general supervision of the financial interests of the company. (See $\S 86$. ) 
Like the secretary, the treasurer may have other duties assigned him in the conduct of the corporate business that do not necessarily pertain to his office.

\section{§ 84. General Manager.}

The general manager while an officer of the company is not so in the same sense as is the president, secretary or treasurer. He is accounted an officerin contradistinction to the employees-only because he is selected by and usually reports to the board. He has no concern with the corporate functions, having charge only of the ordinary business operations of the company which he manages exactly as he might the affairs of a firm or individual. At times he is directed to act under and report to the president. If the by-laws did not specifically provide for the election of a general manager, the board would still have authority to appoint or employ such official and prescribe his duties and salary just as it might appoint any other employee of the company.

The powers, duties, and compensation and term of office of the general manager are usually fixed by the by-laws, otherwise by the board of directors. Generally this officer enters into a contract of employment with the corporation and in such case the contract provisions control.

\section{$\S 85$. Counsel and Auditor.}

In the larger corporations an attorney or firm of attorneys to represent the corporation is retained as 
a regular and permanent feature of the management. Such counsel has no independent authority to act for the corporation, even in matters of litigation, save as such authority is expressly given, usually by action of the board. The principal duties of counsel are to confer with and advise the officers of the corporation in matters of such importance or delicacy as to require legal guidance; to prepare or revise all important contracts or other instruments of the company, and to represent and act for the company when litigation does occur.

An auditor is also usually appointed or elected by the larger corporations. The duty of this officer is to supervise the whole system of corporate accounts and business records. Such officer must of necessity be an expert accountant. His authority and duties are usually prescribed by the by-laws, or otherwise are fixed by the board.

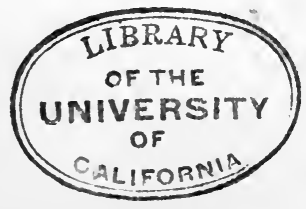




\section{CHAPTER IX.}

\section{THE CORPORATE RECORDS.}

\section{$\S 86$. The Treasurer's Books.}

Usually the treasurer's books are merely the books of account of the corporate business. If the treasurer is not himself the bookkeeper of the company, he is still supposed to supervise and be responsible for the corporate accounting.

There is no system of bookkeeping peculiar to the corporation. Each company keeps its accounts in accordance with its own methods and the general principles of bookkeeping. In a large corporation conducting an extended business, the books are numerous, but this is because of the scope of the business, not on account of any peculiarities of corporate bookkeeping. A capital stock account must be introduced. A dividend account will be necessary to record the disposition of divided profits. A few other accounts peculiar to the corporate form are necessary. A stockholders' ledger may be required. Outside bf these, the books and the accounts they contain are 
much the same as they would be if the business were unincorporated. (See $\S \S 83$, I 50.)

\section{§87. The Secretary's Books.}

The books kept by the secretary are as follows:(I) the minute book, (2) the stock certificate book, (3) the transfer book and (4) the stock ledger.

The minute book contains the records of the corporate proceedings. ( $\S 88$.)

The stock certificate book contains any unissued certificates, attached to their stubs; also the stubs of all certificates that have been issued and usually any certificates that have been surrendered for reissue. ( $\S 89$, I I9.)

The transfer book contains blank transfers to be filled and executed when stock of the corporation changes hands. ( $\S 46,90$; also Forms 61, 62.)

The stock ledger or stock book shows the name and residence of each stockholder with the number of shares owned by him. (See $\S \S 46,9$ I; also Form 6o.)

Large corporations frequently appoint a transfer agent to take charge of the stock certificate book, the stock ledger and the transfer book, thereby relieving the secretary of much labor and responsibility.

\section{$\S 88$. Minute Book.}

It is a matter of the greatest importance that the proceedings of the meetings of stockholders and directors, and, in the larger corporations, of the stand- 
ing committees as well, shall be recorded accurately and properly. This duty belongs to the secretary and the book or books in which his records of the corporate proceedings are entered is called the minute book.

"The minute book of a corporation properly kept is legal evidence of the proceedings of its stockholders' and directors' meetings. The secretary is its custodian and its entries should be made by him alone. Any director has the right to inspect this book at any suitable time. A stockholder usually does not have this right.

"The minute book is ordinarily a blank book of the style termed 'record' by stationers. It may be had at any price from plainly bound books at fifty cents or less, up to elaborately bound and specially printed books costing from five to twenty-five dollars or even more. A reasonably good and substantially bound book is always to be desired.

"The minute book varies in size and general form according to the taste or requirements of the secretary. A common and convenient form is $8 \mathrm{r} / 2$ by $\mathrm{I} 3$ inches. Sometimes the book is specially made, of a size and style to match the other corporate records. For a small corporation with few meetings, a book containing one hundred pages will usually be found ample.

"When the minutes are kept in a substantially bound volume with longhand entries succeeding each other in regular order, later additions or insertions 
are difficult if not impossible, and their evidence as to proceedings at the company's meetings is difficult to controvert.

"Minutes are, however, not infrequently written with the typewriter on sheets of thin paper, which are then pasted in the minute book. Also at times looseleaf minute books are employed, in which the pages may be removed, and, after the minutes are written upon them, be reinserted in the book. When either of these plans is followed, substitutions and alterations in the minutes may be made with comparative ease and their value as evidence is diminished.

"To avoid this objection to the convenient looseleaf minute book, each page is sometimes watermarked with its proper number in such manner that substitution is extremely difficult and practically impossible. The same end is sometimes accomplished by the inscription of the president's and secretary's signatures or initials on each page, making substitution without the participation of these officials impossible. It is obvious that this latter method of verification may also be effectively employed when minutes are pasted into the minute book."*

The first pages of the minute book should contain a copy of the charter or certificate of incorporation of the company. This may be the certified copy received from the Secretary of State (See $\S$ II 7 ), bound or pasted into the minute book; or, equally good, a careful and legible copy made by the secretary directly on

\footnotetext{
* Conyngton on Corporate Management, pages 196, 197.
} 
the first pages. Following the charter should come the by-laws of the company, likewise carefully and legibly copied, and beginning at the top of the first page after the charter. The by-laws should be followed by a certificate signed by the secretary and stating that, as written, the foregoing by-laws are a true and correct copy of the by-laws adopted at the meeting of the stockholders of the company, held at such a time and place. (See Form 14.)

Two or three pages next succeeding the by-laws should be left blank for the entry of any amendments. Then should follow the minutes of the first meeting of stockholders, then the proceedings of the first meeting of directors, and thereafter the minutes of stockholders' and directors' meetings in due sequence as held. Each meeting should begin at the top of its proper page, and no blank pages should be left between the records of the different meetings.

Usually the minutes of the directors and of the stockholders are kept in the same volume. In the larger corporations, however, separate minute books are kept for the respective records of the directors and stockholders. There is no objection to separate books in the smaller corporations if so desired, and, on occasion, they are necessary.

When notification of some action taken at a meeting is necessary, as for instance the acceptance of a contract or proposition, a transcript of such part of the minutes as applies is made by the secretary and is evidenced by his signature and the seal of the com- 
pany. This is then delivered to the parties in interest as formal and sufficient notice of the action taken. (See Forms 52-54.)

The minutes given in the latter part of the present volume (See Chs. XxII, Xxv) are in conventional form. There is, however, no set form nor absolute rule as to how the minutes of a meeting shall be recorded, and any clear statement in good English is legally sufficient. Usually the conventional arrangement will be found clearest and most concise, and should be followed.

During the progress of a meeting many letters, reports, contracts and other instruments are likely to be presented. In some cases the secretary is instructed to enter certain of these upon the minutes, but in other cases it rests in his discretion whether these documents be entered in full, in part, or be entirely omitted. Generally it is sufficient if they be filed and preserved, with only such reference to them in the minutes as will suffice to identify them, or explain their connection with the action taken. If, however, the matters to which they relate are important, they might well be entered in full, or, as it is phrased, "spread upon the minutes." When this is done the minutes constitute a complete record in themselves, which is sometimes a matter of much importance.

The minutes should be written up in permanent form as soon after the meeting as possible, and while its events are fresh in the secretary's mind. If he is in 
doubt about any part of the proceedings, he may ask assistance from the president or members present at such meeting. He, however, must take the final responsibility of making the authoritative record which he signs.

The secretary should spare no pains to secure accuracy in the minutes, for they are the legal evidence of the action taken at the meetings recorded, and the authority for any action of the officers required thereby; and they will probably be referred to and acted upon before the formal approval of the stockholders, or directors, relieves the secretary from further responsibility.

The minutes of a meeting are signed by the secretary and by the presiding officer of that meeting. The minutes so evidenced should be read at the next succeeding meeting of the body to which they pertain, and, if no objection is offered, should be approved. The stockholders could not approve the minutes of a board meeting nor could the board approve stockholders' minutes. Neither would minutes of a meeting be approved at a subsequent special meeting of the same body unless such approval were one of the specified purposes of that special meeting. Any unapproved minutes of a body may, however, be approved at a regular meeting of that body without special notification.

The minutes of a stockholders' meeting will probably not be passed upon until the following annual meeting, when they will be read, and, if no objections 
are offered, approved. If approved, no record need be made save the statement in the minutes of the last held meeting that the minutes of the previous meeting were read and approved. Sometimes, as a matter of convenience, the secretary will endorse at the bottom of the minutes, after approval, "Read and approved at the Annual Meeting, September 24th, 1909," or whatever the date may be.

If objection is made to the form or substance of minutes as read, the president might, if the points objected to were obviously incorrect, order them corrected. Should the error be more serious, the correction might be ordered by formal motion, or, in the absence of objection on the part of those present, might still be directed by the president or chairman. In such event, the minutes of the meeting then in session should show exactly what correction was directed and in what minutes. In the corrected minutes the required changes should appear in red ink, and a marginal reference should give the date of the meeting at which such correction was directed. A single red ink line might be drawn through any part ordered stricken out, and corrections may be interlined or be written on the margin, but no erasure should be made in any case, as the corrected minutes should show both the error and the correction. This then shows the entire occurrence; that the record was made in one way, and was, at a later date, ordered changed.

The secretary has no discretion in this matter, but 
must correct his minutes in accordance with the instructions of the meeting even though he may feel sure that his original entry was the true one. The meeting has full authority to say what shall be put in the minutes and what shall be excluded and the secretary can not gainsay that authority.

It sometimes happens that a stockholder or member, opposing some proposed action, wishes his objections or protest recorded in the minutes. If his objections are pertinent and not too lengthy, this should usually be done; but the presiding officer, not the secretary, would decide the matter, and the secretary should be guided by the president's directions. The objecting member will sometimes file his objections or protests in writing, and in such case the document should be received and filed, and the fact that it was received and filed be noted in the minutes.

Also at times it is necessary for a board member to file his dissent from or protest against some improper or objectionable board action, in order to avoid liability for such action. In this case he has the right to demand the entry upon the minutes of his dissent or protest. The president will, however, decide whether such matters shall be entered or excluded, and the secretary must be governed by the president's decision. (See generally, Chapters $\mathrm{xxv}$ and xxvi.)

\section{§ 89. Stock Certificate Book.}

Any stockholder whose stock is paid for in full, or who has paid therefor the full price demanded by 
the corporation, is entitled to a stock certificate, or certificates, in evidence of his holdings. (See $\S \S 34$, 42, 43.) These certificates are usually printed, lithographed or engraved, and attached to individual stubs, are numbered consecutively from one up to the total number, and are bound together in a book which is designated the stock certificate book. When a new book becomes necessary the numbering is carried on beginning with the next number above the highest in the old book. A line of perforations between each certificate and its stub renders easy the detachment of the certificate when issued.

Fifty to one hundred of these certificates are usually deemed sufficient for a corporation in which transfers are not likely to be numerous. For the larger corporations or for those in which the stock is active, the certificates are provided in books of five hundred to one thousand certificates and sometimes many volumes are required.

If the corporation issues preferred stock, the certificates of this stock are usually bound separate from the common stock certificates, though in the smaller corporations to avoid expense and the multiplication of books both kinds of stock are sometimes bound together in one book. Preferred stock certificates are also numbered independently of the common stock certificates. The preferred stock certificates should always be marked in some way to clearly distinguish them from the common stock certificates, and the preferences enjoyed by this stock and the condi- 
tions of its issue, unless too lengthy, should appear upon the face of the certificates: Usually the preferred certificates are distinguished by having the word "Preferred" printed or tinted in on the face of the certificate, though there is no invariable rule as to the distinguishing marks. (See Forms 4, 5.)

When certificates are surrendered for reissue or for other reasons, they are cancelled-either by punching, or with a cancelling stamp-and the cancelled certificate is then pasted to the stub from which it was originally detached. The proper entries are then made on the stub, and the certificate and its stub present a complete record of the issue and return of the certificate in question.

The certificate book is kept by the secretary and remains in his custody.

\section{$\S$ go. Transfer Book.}

The transfer book is composed of a series of blank transfers. (See Forms 61, 62.) These transfers are intended to be filled out when stock is to be transferred, and, when signed by the owner of the stock or his duly authorized attorney, become the secretary's authority for the issue of new certificates of stock in place of the old certificates surrendered.

In some few states the transfer book is required by statute. By reference to the assignment on the back of a stock certificate (Form 6) it will, however, be seen that the transfer book merely duplicates the assignment of the certificate. For this reason the 
transfer book is not essential, and, where not required by statute, is frequently omitted by the smaller corporations. In such case the secretary depends upon the duly assigned stock certificate for his authorization to make desired transfers. The method from the legal standpoint is sufficient.

It is customary among the larger corporations to appoint transfer agents who assume the entire supervision of the issue and transfer of stock. These transfer agents are usually trust companies or other responsible institutions and by their appointment both accuracy and responsibility are secured.

In New Jersey and some other states, the transfer book is the final authority as to the voting rights of stockholders. In most of the states the stock ledger controls. (See § 9r.)

\section{§ 9r. Stock Ledger.}

The stock ledger or stock book contains the name and address of each stockholder of record, the number of shares received and the number, if any, transferred by him, the date of such receipts and transfers and the number of shares remaining at any time in his name. (See $\S 46$; also Form 6o.)

When stock is received, the holder is credited in the stock ledger with the number of shares so required, and when he transfers part or all, he is debited with the number of shares transferred. The balance, if any, will always be on the credit side and will show the number of shares upon which the stockholder is entitled to vote and draw dividends. 
The statutes usually require that a stock ledger be kept and that it be always open during business hours to the inspection of any stockholder of record or judgment creditor.

In New York the statutes require a "stock book" to be kept. This stock book is merely a stock ledger with some additional data as to the stock and its owners.

The stock book or stock ledger is usually regarded as the most important of the stock records, and usually controls; $i$. e., in event the right of a stockholder to vote or to draw dividends is to be determined, the matter is settled by reference to the stock ledger. If his name appears there, he is a "stockholder of record," entitled to vote and draw dividends upon the shares of stock standing to his credit.

In some few states, however-notably New Jersey-by special statutory provision the transfer book controls, and in case a stockholder's right to vote is questioned, the matter must be decided by reference to this book. 


\section{CHAPTER X.}

\section{DIVIDENDS AND FINANCES.}

§ 92. Dividends.

The matter of declaring dividends rests in the discretion of the board of directors. They decide when a dividend is to be declared and how much it shall be.

Dividends may be legally declared only from surplus or net profits. If paid from the capital or obtained in any way that will impair the capital of the company they are illegal. The directors render themselves personally liable for declaring such dividends and should the corporation become insolvent the amounts so paid to stockholders may be recovered from these stockholders for the benefit of creditors.

Dividends must be equal as between holders of the same class of stock. Particular stockholders may not be favored either in time or amount of payment. Dividends are paid only to stockholders of record. ( $\S 47,91$.) If stock has been sold and the purchaser has neglected to have the transfer made on the books of the company, any dividends, unless the treasurer is duly and formally notified of the transfer, are paid to the former owner and the purchaser who is the 
equitable owner of the stock, must look to him for satisfaction. Dividends can not be refused a stockholder of record because of the absence or loss of his certificate. (See $\S \S 42,45$.)

\section{$\S$ 93. Working Capital.}

Usually when a corporation is organized some part of the capital stock is sold to provide working capital. Or when stock is issued for property, frequently a portion of this stock will be returned to the treasury as a donation, to be sold for this purpose. Or working capital may be included in the property turned over to the corporation.

To provide for later necessities the by-laws sometimes specify that a certain proportion of the profits shall be set aside for working capital before any dividends are paid, or shall be so set aside until a certain amount has been reserved. In the case of New Jersey corporations some such by-law is necessary if working capital and reserves are to be accumulated, as otherwise under the statutes all profits must be paid out as dividends. In most of the states the directors may use their discretion, reserving only such amount as they deem necessary for working capital, and, before or after doing so, paying such dividends from profits as they think best.

\section{§ 94. Debt.}

Certain restrictions upon the power of the board to incur debt are sometimes inserted in the by-laws. 
The usual form this takes is a requirement that no indebtedness beyond a limited amount for current expenses may be incurred unless authorized by a twothirds vote of the entire board, or, on occasion, an authorization from the stockholders will be required. (See $\S \S$ II5, I39.) The assenting vote of a specified proportion of the stockholders should always be required before the board may mortgage the corporate property. In many states this is provided by statute. The usual method of corporate borrowing is by the issue of bonds secured by mortgage upon the real, and sometimes upon the personal property of the corporation.

\section{§ 95. Bank Deposits.}

The moneys of a corporation should be deposited in the name of the corporation in some bank or trust company designated by the board of directors. (See Form 52.) Such deposit should be in the name of the company and moneys deposited therein should be drawn out only by checks, signed by the treasurer and countersigned by the president or by such other officers as may be properly authorized thereto. (See Form 55.) The by-laws usually direct such disposition to be made, the board at its first meeting selecting the bank. 
CHAPTER XI.

\section{SUNDRY DETAILS.}

\section{$\S 96 . \quad$ Corporate Offices.}

A corporation is usually required to maintain a socalled "principal office" in the state in which it is incorporated. It may have other offices either within or without the state and these offices may be and frequently are larger and more important than the designated principal office, but this latter is still, from the legal standpoint, the principal office and the headquarters of the corporation. Certain of the corporate records are kept in the principal office and usually an agent must be kept in charge upon whom legal service, as against the corporation, may be made.

The principal office is the usual and most suitable place in which to hold meetings of the stockholders, and in some states the statutes provide that such meetings must be held in this office. The directors have much more latitude than the stockholders as to their place, or places of meeting, but, in the absence of good reasons to the contrary, should also meet in the principal office. The by-laws usually provide that all reg- 
ular meetings both of stockholders and directors shall be held in the principal office.

\section{§ 97. Corporate Seal.}

The corporate seal is either provided for in the bylaws and is therefore adopted with the by-laws, or, otherwise, is adopted by direct resolution of the board of directors. No particular form of seal is required by the statute law, but, as a matter of practice, it should bear the name of the company, the state of incorporation and the year in which the incorporation was effected.

The corporate seal must be used in the execution of corporate deeds, mortgages and all other instruments of such nature as to require a seal when executed by an individual. It is also employed to authenticate certificates of stock, transcripts of motions or resolutions, and such other corporate instruments as may require formal authentication. An ordinary corporate contract, or promissory note does not require the seal, nor is it usual to affix it to the corporate checks. Its use on such instruments does not affect them in any way.

The secretary is usually the custodian of the seal and it is his duty to affix it to resolutions or other corporate documents when necessary, or when directed so to do by the board of directors, and, generally, when required in the course of his regular duties. (See Forms 48 and 58 for use of seal.)

The board of directors may, in its discretion, au- 
thorize any officer of the company to affix the corporate seal.

\section{$\S$ 98. Execution of Contracts.}

Corporate contracts are authorized by resolution of the board of directors and it is the general rule that an officer of a corporation must be so authorized before he can legally contract for the corporation. In practice, however, this rule is somewhat relaxed. The officers customarily make contracts in minor matters incident to their official duties without express authorization. Also in more important matters, if the officers have been habitually permitted to contract for the corporation without specific authorization, such contracts unless obviously in excess of the proper official powers, are binding on the corporation. If, however, the officers have been allowed to so contract only in particular directions, their contracts, while binding in these directions, are not binding as to other matters unless authorized by the board.

For instance, if the corporation has habitually allowed its president without express authorization to make contracts for machinery and lumber and material used in the corporate operations, such contracts though not specifically authorized are binding on the corporation. If, however, he should go further and contract to purchase real estate, or other property outside the usual routine, such contracts, unsupported, are not binding on the corporation. The board might repudiate any such contract absolutely, or ratify it 
either by express resolution or by accepting the benefit of the transaction.

When an important contract is authorized by resolution of the board, the resolution usually empowers one or more of the corporate officials to execute the contract for the corporation. In such case, a certified transcript of the resolution, signed by the secretary and sealed with the corporate seal is the proper evidence of the officials' authority in the matter, and, if the contract were one offered to the corporation, sufficient evidence of its acceptance by the corporation. (See Forms 52-54.)

The deed, mortgage or other instrument involved in any such contract should close with a testimonium (See Forms 48, 58) reciting the authorization under which the officials are acting, and should be signed by them with the corporate signature and be sealed with the corporate seal. 


\title{
PART III.-CORPORATE ORGANIZATION.
}

\author{
CHAPTER XII.
}

INCORPORATION.

\section{$\S 99$. Subscription Lists.}

Formerly when the organization of a corporation was contemplated, subscription lists were almost invariably circulated as a preliminary. Then if sufficient subscriptions to the stock were secured, application was made for a charter and the corporation was organized.

This plan is still pursued but not so commonly. Corporations are in most cases organized to take over particular properties or businesses and the subscription list is not brought into play. In such cases the only preliminary subscriptions are the formal subscriptions of the incorporators who sign the application for the charter.

When the subscription list is employed its form varies with the circumstances. Subscriptions under it are held to be continuing agreements by the subscribers to take the number of shares specified, and, 
unless otherwise stated, at par and for cash. Usually the terms of payment are set forth in the instrument. All the conditions of subscription should appear on the list and any material change of these will release the subscriber. It is also customary and safe to have all the essential features of the proposed incorporation appear upon the subscription list. Then there can be no question on either side as to the terms under which subscriptions were made.

Under the usual form, subscriptions may be canceled at any time before the organization of the corporation. To render them binding from the time they are made, agreements with trustees and other special forms of subscription lists are sometimes employed. (See generally $\S 4 \mathrm{I}$; also Forms I, 2, 3.)

\section{$\S$ roo. Application for Incorporation.}

In former days application was made to the state legislature when a charter was desired. The grant was then a special charter to specified persons, authorizing them to conduct some particular enterprise under the corporate form. Usually these charters conferred some franchise or special privilege, as the right to erect a toll bridge, establish a bank, construct a railroad or build a dam.

The abuses arising from this method of granting charters have resulted in the prohibition of special charters in most states. Instead, general laws have been provided under which corporations for any legitimate purposes may be formed by any qualified 
persons upon compliance with prescribed formalities. In some few states special charters are still granted on occasion, though the majority of their corporations are formed under general laws. (See $\S \mathrm{I} 8$.)

The form of application for a charter under these general laws is usually merely a copy of the charter desired, or, in other words, the charter application when allowed becomes itself the charter. The charter application sets forth the names of the applicants and the name, purposes and other required details of the projected corporation. It is executed by the incorporators, and, after its allowance by the Secretary of State, is filed in his office. It must also usually be filed in the office of the clerk of the county in which the corporation is domiciled or has its home. If the proposed corporation is for proper purposes, if all fees have been paid, and the application is in due form, it is accepted and filed as a matter of course, and the parties are then authorized to proceed with the organization of the corporation. (See $\S$ II 7 .)

The details usually required in an application for a charter are discussed in the sections which follow. (For Charter Forms see Chap. xIx.) In most of the states the requirements are much more severe when charters are to be taken out for financial and public service corporations.

\section{$\S$ IOI. (a) Incorporators.}

The parties applying for a charter must be competent persons of full age, and, ordinarily, some pro- 
portion of them must be citizens of the state in which the application for charter is filed. Minors, firms or corporations, and, generally, persons not able to contract, are not competent parties, though they may usually hold stock after the corporation is formed. The minimum number of applicants is in most states three, though in some few states five are required. Each incorporator must ordinarily subscribe for one or more shares of stock and all must sign and acknowledge the application.

As a matter of convenience incorporations are usually effected with the smallest number of incorporators permissible, other interested parties coming in after organization. "Dummy" incorporators, or incorporators without any special interest in the matter, are frequently employed both as a matter of convenience, and, at times, to conceal the identity of the real parties in interest. (See $\S$ I23, I47.)

\section{$\S$ I02. (b) Name of Corporation.}

Wide latitude is usually allowed in the selection of the corporate name. The principal restriction is the prohibition of names like, or nearly like those of corporations already rightfully doing business in the particular state. In some states all corporate names must begin with "The" and end with "Company." In others the name must be followed by "Limited" or "Incorporated." In many states firms may become incorporated under the partnership name without change or addition of any kind. (See § I43.) 
In most states companies organized for ordinary business purposes are not allowed to use the words "guarantee," "trust," "bank," "insurance" and the like in the corporate designation.

For practical reasons corporate names should be distinctive and not too long.

\section{$\S$ ro3. (c) Purposes.}

The purposes for which a corporation is to be formed must be set forth in the application and must be such as are permitted by the laws of the particular state. Ordinary business corporations are allowed much latitude in stating their purposes and are not usually confined to one business or line of activity. In some of the leading corporation states the only important restriction is the prohibition against extending the charter purposes to banking, insurance, transportation and those similar enterprises which are only allowed to corporations organized under special laws and with special formalities. Outside of these any number of purposes and diverse businesses may be included in one application. Since a corporation has no legal right to do any business not permitted by its charter, care should be taken to make the purposes sufficiently comprehensive to meet all proper corporate needs. (See § I9.)

The insertion of illegal purposes, or of purposes not permissible under the statutes, is ground for the rejection of a charter application. Even if such an application were inadvertently or wrongfully accepted 
and filed by the state officials, it would be void as to these illegal provisions.

\section{$\S$ ro4. (d) Capitalization.}

The capital stock of the proposed corporation must be specified in the application and may be changed thereafter only by amendment of the charter. In most of the states there is no maximum limit to capitalization, though a minimum amount is usual; thus in New York there is a requirement that it shall not be less than five hundred dollars, and in New Jersey that it shall not be less than two thousand dollars. In many states there is no limitation of capitalization in either direction. (See $\S 34$.)

\section{§ 105. (e) Shares.}

In most states of the Union the par value of shares of stock may be fixed by the incorporators at discretion. General restrictions are found in some few states, as in New York where the par value of the share must not be less than five dollars nor more than one hundred dollars.

One hundred dollars is the most convenient and most generally adopted par value for shares of stock. Mining companies, however, frequently issue shares as low in value as one dollar, and shares of the par value of ten dollars are not uncommon. The small share is convenient when small investments are to be invited, or when an impressive offering of shares for a small amount of money is a desideratum. (See § 34.) 


\section{§ ro6. (f) Location.}

A corporation must have a principal office in the state in which it is incorporated, and the location of this office must usually be specified in the application for its charter. It is customary to specify in the application that the company is to have the right to maintain other offices and to do business elsewhere either within or without the state. Unless expressly prohibited by the laws the corporation would, however, have this right without specification in the charter. (See $\S 96$.

In the state of its incorporation the company is a "domestic" corporation. Elsewhere it is a "foreign" corporation. In its own state it has certain legal rights as an incident of incorporation. In other states it has no such rights except as a matter of courtesy or as they may be granted it by the legislation of such other states. This is so because as an artificial person it does not come under the protection of those constitutional provisions which guarantee to the citizens of one state "all privileges and immunities of citizens in the several states." It may therefore be absolutely prohibited from doing business in another state, save in so far as it may be engaged in interstate commerce, with which state law can not interfere.

\section{$\S$ I07. (g) Duration.}

In some states the duration of corporations is limited to some fixed maximum as twenty, thirty or fifty 
years. In most states, however, while a corporation may be limited to any term specified by its charter, it is permissible to express its duration as perpetual. At the expiration of the term fixed by the law, or specified by its charter, the corporation terminates and then, unless its charter be extended, must be wound up. If this were not done the stockholders might be held liable as partners in any transactions subsequent to the expiration of the corporation's allotted period. (See $\S$ I4, 25.)

\section{$\S$ ro8. (h) Number of Directors.}

The number of directors of the corporation must in most states be specified in the charter application. The minimum allowed by law is usually three. It is but seldom that a maximum number is specified. In many states the number of directors may be fixed or altered by the by-laws.

A large board of directors is apt to be cumbersome, difficult to assemble and ineffective. For this reason a small board is preferable where the conditions will permit. Where a large board is unavoidable it usually necessitates the formation of an executive committee which manages the affairs of the corporation, and, practically, takes the place of the board. (See $\S \S 6 \mathrm{I}, 73$.

\section{$\S$ rog. (i) Directors for the First Year.}

Under the laws of many of the states the directors for the first year must be designated by the charter. The plan is a convenient one. In the greater number 
of the states, however, the first board of directors is elected by the stockholders at their first meeting. It is a common requirement that one or more members of the board of directors must be citizens of the state of incorporation. (See $\S$ I23.)

\section{$\S$ I Io. (j) Charter Subscriptions.}

In a majority of the states the incorporators of a corporation must be subscribers for one or more shares of the company's stock. The names of these subscribers, their post-office addresses and the number of shares subscribed for by each must be specified in the charter application. (See $\S 4 \mathrm{I}$.)

\section{$\S$ III. (k) Classification of Stock.}

Under the laws of most of the states, stock may be classified in various ways. The most common classification is into common and preferred stock. (See Chap. v.) Another common classification is that of voting and non-voting stock. Sometimes stock is classified so that each class of stock elects one or more directors. ( $\S \mathrm{I} 37, \mathrm{I} 45$.

\section{$\S$ II2. (1) Cumulative Voting.}

The cumulative system is a modification of the ordinary system of voting designed to secure a more equitable composition of the board of directors than is otherwise usually possible. It is employed only in the election 'of directors. Under its operations the holders of minority stock who are ordinarily left absolutely without representation among the directors, 
may, if their holdings are at all material, unfailingly elect one or more directors and thereby secure due representation on the board.

In some states cumulative voting is prescribed by statute and must be permitted by all corporations organized under the laws of those states. It may be obtained by proper charter or by-law provisions in almost all the states.

A fuller discussion of cumulative voting will be found under "Protection of Minority," in Chapter XV of the present volume. ( $\S$ I35.)

\section{$\S$ Ir3. ( $\mathrm{m}$ ) Holding Stock in Other Companies.}

For one corporation to hold the stock of another is contrary to the general principles of corporation law, and is not allowable unless expressly allowed. In New Jersey and some other states, the right is granted by statute to all corporations organized under their laws. In some other states it may be secured by the insertion of special provisions in the charter application.

The original prohibition against the holding of corporate stock by corporations was intended to prevent the control of one corporation by another. In the present day this very end has on occasion been found desirable and the existing relaxation of the rule is for the express purpose of permitting corporations to secure control of other corporations by purchase of their stock. By this method many of the great industrial combinations of recent times have been formed. 


\section{$\S$ II4. (n) Powers of Directors.}

The general powers of the directors are secured to them mainly under the common law. In many of the states these powers can not be enlarged or extended by charter or by by-law provisions. In some states, however, as in New Jersey, they may be materially increased by suitable charter provisions. In this way the directors may be given power to make and amend by-laws and do other things not permitted under the general law.

In most of the states the powers of the directors may be restricted to a greater or less extent by charter or by-law provisions. Some of the more usual of these limitations are noted in the next section. (See Chap. vir for general powers of directors.)

\section{$\S$ Ir5. (o) Limitations on Salaries and Indebtedness.}

Limitations on the powers of the directors, if not so restrictive as to interfere with their proper freedom of action, are in some cases of material advantage to the stockholders. Common limitations are regulations as to the amounts to be paid in salaries and as to the total indebtedness that the directors may incur on behalf of the corporation. Some flexibility is generally given to these regulations by a provision that the limits set may be exceeded with the consent of some specified majority of the stockholders, or perhaps of the directors.

For instance, the maximum salary to be paid any official may be fixed at $\$ 2,500$ per annum, or some 
specified sum may be named as the limit of the corporate indebtedness, these bounds not to be exceeded unless the directors are authorized thereto by a twothirds vote of the entire outstanding stock of the corporation. At times the same end will be attained by a by-law provision that some specified majority of the board, as two-thirds, three-fourths or even the entire board, must concur in any increase of salaries or indebtedness above the by-law limits.

Sometimes the salaries to be paid officers will be made dependent in a measure on the profits earned, or upon the dividends paid, and the power to incur debts or liabilities will be limited to some' definite proportion of the assets of the company. (See § I39.)

\section{§ II6. Execution of Certificate.}

The charter application having been duly made out in conformity with the laws of the state of incorporation, is signed-usually in duplicate-by the incorporators. It is then acknowledged before some officer authorized to take acknowledgments to deeds, and is ready for filing. (See Forms 8-IO.)

\section{$\S$ II7. Filing and Recording.}

Under the usual procedure, the duly executed application, accompanied by the proper fees, is sent to the office of the Secretary of State while another copy is filed with the county clerk of the county in which the proposed corporation is to have its principal office, Each state has its own minor variations in procedure, 
which will be found in its statute law. In New York the state fees must be sent to the State Treasurer. When these fees are received, the Treasurer certifies that fact to the Secretary of State and this latter official will not file the charter until this certification is received. In New Jersey the application is filed with the county clerk first, and a copy certified by him is then filed with the Secretary of State. In some states, the application must receive the approval of the judge of a specified court before it will be filed.

If the application for charter is in due shape and all fees are paid, it is accepted and filed as a matter of course. Having been drawn in the form of a charter, or certificate of incorporation, the application becomes, when filed, the charter of the corporation, the existence of the corporation dating from such filing. In some states, as soon as filed, a copy of the charter under the great seal of the Secretary of State is forthwith sent to the incorporators as a matter of course and is evidence of the due incorporation of their company. In other states, the incorporators are merely notified that their application is accepted and filed. Then if they desire copies of the charter, certified by the Secretary of State, they may secure them by the payment of certain additional fees. (See $\S$ IOO.)

\section{§ II8. Fees and Expenses.}

The different states regulate the fees for incorporation according to the varying views of their legislators, and there is for this reason wide differences 
in the cost. In some states-more particularly in the western part of the country-one uniform state fee is charged for all incorporations, as in Washington where twenty-five dollars is the fixed filing fee regardless of the amount of capitalization. In most of the states, however, the fees vary with the capitalization and are usually a certain small percentage upon the total amount of the capital stock. In all the states there are sundry minor fees that are paid to different officials for their services. (See Form II.)

In most of the states after incorporation special annual franchise taxes are imposed. These taxes are in addition to the taxes levied on property, which are the same for a corporation as for an individual. They are in some states a fixed amount imposed without regard to capital stock, but usually vary with the capitalization. Exemptions are often granted to manufacturing corporations employing all or the greater portion of their capital within the state limits. (See Form 12.)

\section{§II9. Books, Stock Certificates and Seal.}

It is desirable that a corporation shall keep a stock ledger. For the larger corporations a transfer book will be found necessary. In some states these books are required by statute. The stock ledger is a record showing who are stockholders, when they became stockholders and how much stock they hold. The transfer book consists of blank transfers which are filled out and executed when stock is transferred 
from one person to another. Sometimes the transfer book will be omitted, the secretary relying upon the assignment upon the back of the stock certificate for his authority to make transfers. (See $\S \S 46,87,90$, 9I.)

The stock certificate book consists of certificates of stock partially printed and numbered from one up, each attached to its respective stub and with blanks left to be filled in at the time of issue with the name of the owner, number of shares owned, date of issue and signatures. (See $\S \S 42,43,89$.

A seal is also a necessary feature of the corporate equipment. (See $\S$ 97.) Likewise a minute book. (See $\S 88$.) A neat and serviceable outfit consisting of stock books, minute book, stock certificates and seal may be had for ten dollars. Cheaper outfits may be obtained, but are not advisable. From these minimum figures the cost of an outfit ranges far upward, depending upon the style and binding of the books and the character of the certificates. 


\section{CHAPTER XIII.}

\section{FIRST MEETING OF STOCKHOLDERS.}

§ r20. Preliminary.

In the great majority of the states the allowance of the charter must precede the organization of a corporation. In a few states under the statute requirements this procedure is reversed, the incorporators meeting and arranging the organization of the corporation before its charter application is even filed.

When a corporation is created by the allowance of its charter, it already has the statute law and the provisions of its charter for its guidance, but it has usually neither directors, officials nor by-laws. All these must be provided before the corporate operations may properly begin. The adoption of by-laws and election of directors and officers are the essential features of the organization of the corporation, and are the first matters demanding the attention of its stockholders.

Under the usual procedure as soon as the charter is allowed the stockholders meet, adopt by-laws and elect directors. These directors meet as the next 
step and complete the corporate organization by the election of officers. The corporation is then equipped for the proper exercise of its corporate functions.

In a few states the directors for the first year are named in and appointed by the charter. When these directors are empowered to adopt by-laws, they can complete the organization of the company without action of the stockholders. In such case the first meeting of stockholders loses much of its importance and is sometimes omitted. When held the election of directors is passed over, but by-laws are adopted and such other action taken as may be necessary.

The first meeting of the stockholders is simply a special meeting, its particular purpose being the organization of the corporation. (See § 53.) As a special meeting it must be called with all due formality. The simplest and most convenient plan for its assembling and the one usually employed, is for all the incorporators to join in a call and waiver. (See Form I7.) This designates such convenient time and place for the meeting as may be agreed upon, states its purposes, and expressly waives any further requirements as to notice. The call and waiver is always allowable as a means of assembling a meeting. If, however, for any reason it can not be used for the first meeting and no other method is prescribed by the statutes, a call might be issued by the majority of the incorporators and be duly served by advertisement or by personal service upon those entitled to attend this first meeting. 
In most states the incorporators are authorized by express statute provision to call and hold this first meeting of stockholders, though in the absence of such provision they still have this necessary authority. The incorporators may usually give proxies if they wish and it is not uncommon for a first meeting to be held without a single member of the company being present in person. Those who are in attendance act and conduct the meeting solely by virtue of the proxies given them by the absent incorporators. (See $\S 57$; also Form I6.)

The first meeting of stockholders is usually purely formal. The organization of the company and any important action is agreed upon in advance, and minutes are prepared in accordance. At the meeting the minutes are followed to the letter. To such an extent is this practice carried at times, that the attorney in charge merely reads his prepared minutes to the assembled incorporators and no other action of any kind is taken. If such a meeting is properly called, if a majority of the incorporators are present, and if no objections are offered, the minutes as read are held to be a record of the proceedings of such meeting and can not be later set aside.

Usually, however, the first meeting is less perfunctory, and, while the minutes may be prepared in advance, they are used merely as a memorandum of the necessary proceedings, the actions of the meeting being carried through in due form. This is the better practice and is the procedure outlined in the present chapter. (See Forms 22, 23.) 


\section{$\S$ I2I. Opening the Meeting.}

Pursuant to the call and waiver, or such other due notice as may have been given, the incorporators assemble at the appointed time and place and choose a temporary chairman. With the consent of the meeting the chairman appoints a temporary secretary, or the meeting may choose this official.

The chairman then asks for the call and waiver, or such other call or notice as has been used to assemble the meeting, and, in the absence of objection, usually orders this entered on the minutes. The same end may be attained by formal motion if preferred. The names of those present should be recorded in the minutes, and the fact that all or a majority of the incorporators were present should be stated. If any are present by proxy that fact should also be noted.

The charter is then presented to the meeting with a statement that it has been allowed-the date of allowance being given-and that all statutory requirements have been fulfilled. The instrument is usually ordered spread on the first pages of the minute book. (See $\S 88$.)

\section{$\S$ I22. Adoption of By-Laws.}

The next step is the adoption of by-laws. The preparation and full consideration of these by-laws is too formidable an undertaking to be left until the time of the meeting. Usually, therefore, they are drafted by the attorney in charge and are fully considered by the incorporators and any other interested parties, prior to the meeting. 
If the by-laws have been prepared with careful consideration and have been fully agreed upon in advance and all are familiar with their provisions, they will frequently be presented to the meeting as a whole, and be adopted as presented. The usual and the safer plan is, however, to have them read, article by article, each article being adopted as read; then at the conclusion a motion is made adopting them as a whole and directing that they be entered on the minutes immediately succeeding the certificate of incorporation. (See $\S \S 31,88$; also Forms I3, 14.)

These by-laws are the working rules of the company. They become effective as soon as adopted and the next proceedings of the meeting are conducted in accordance with their provisions.

\section{$\S$ I23. Election, of Directors.}

As has been said, in some few states the directors are named in the certificate of incorporation and the election of directors at the first meeting of stockholders is, then, necessarily, omitted. In the other states it is one of the most important features of the stockholders' first meeting. It usually follows the adoption of the by-laws. Tellers or inspectors of election should be appointed and the election be by ballot. (See Forms 69, 69a.) Nominations may be made, or the matter may be left open, each incorporator voting for such qualified persons up to the number of directors to be elected as he sees fit. The 
number of votes each casts will be determined by the amount of his stock subscription, usually one vote for each share subscribed. Care should be taken that those elected be legally qualified to act. In the greater number of states it is required that each director shall own one or more shares of stock; also that one or more of the directors shall be citizens of the state of incorporation.

Where stock requirements exist and persons whom it is desired to have upon the board are not stockholders, it is a common practice to place one or more qualifying shares of stock in their respective names. This results in the so-called "dummy directors"that is, directors who have no material interest in the corporation, but who are elected to hold the place temporarily or to represent or act in the interests of others. If sufficient stock has been given these dummy directors to make them eligible and the laws of the state are complied with in the details of election, they have the same rights and powers in the management of the corporation that any other directors would have.

Usually it is either known or ascertained before the election that the persons voted for will accept the position of director if elected. Awkward contingencies occasionally arise from the refusal of directorselect to accept the position to which they have been elected. It is better to forestall such possible difficulties by determining the matter as far as may be in advance. (See Chap. vir; also Forms 67, 68.) 
$\S$ 124. Proposal to Exchange Property for Stock.

Most modern corporations are organized to take over an existing business, or some special property, all or part of the stock of the corporation being issued in payment therefor. In such case it is an important part of the proceedings of the first meeting of stockholders to approve the purchase of the property to be acquired and to authorize the issue of so much of the company's stock as may be necessary in connection therewith.

The simplest method of arranging the whole matter is for the owners to make a written proposal to the corporation, offering the business or other property in exchange for all or a part of its stock. This proposal is brought up in the stockholders' meeting and read in full. After this reading it may be ordered spread upon the minutes, but, as the proposal is presented to the first meeting of directors a little later, and it is not necessary that it should appear in full upon the minutes of both meetings, it is usually, and better, left for entry in the minutes of the directors' meeting. In such case the proposal is merely read and the meeting then passes on to its consideration. (See Forms 19, 22.)

\section{§ 125. Resolution Approving Exchange.}

If the proposal for exchange of stock for property is acceptable as presented, a resolution is adopted approving the proposed exchange and specifically authorizing and directing the board to take such action as 
may be necessary for its consummation.

(See Form 20.)

The preamble of this authorizing resolution usually recites or refers to the main features of the proposal, agrees to its acceptance with the direct statement that the property to be so acquired is necessary for the purposes of the company, endorses the valuation placed upon this property and concludes with specific.instructions to the directors to accept the proposal and to do all such things as are necessary to make their acceptance effective.

The adoption of this resolution effectually commits the stockholders to the purchase of the property, to the valuation placed upon it and to the issuance of the specified stock in exchange therefor. They and their assignees are thereby debarred from any later objection.

In most cases the directors have power to accept a proposal of this kind for the exchange of stock for property without direct authorization from the stockholders. The matter is, however, so important that it is usually deemed best to have the assent of all interested parties.

\section{$\S$ I26. Other Business.}

The adoption of by-laws, election of directors and authorization of these latter to any specially important action, completes the usual business of the stockholders' first meeting. Other matters may be brought up for the stockholders' consideration, but it is seldom that any further action of moment is taken. 
It is to be noted that the wishes of the stockholders as to the future conduct of the company or its business should be embodied in the by-laws. Under the conditions which usually obtain, resolutions instructing or restricting the directors are of no legal effect. Embodied in the by-laws the same directions would, if proper in themselves, be binding upon and control the board of directors.

With the completion of the business brought before the first meeting, the stockholders usually adjourn sine die, not to again assemble until the regular annual meeting, or until sooner called together in special meeting. If, however, the business before the meeting is not completed, or other matters are coming up shortly which will require the action of the stockholders, the first meeting may be adjourned until some fixed future date. It will then reassemble at the appointed time without formality and resume its session. It is merely a continuation of the original meeting and as such does not require any further call or notice to the stockholders. (See Form 22.) 


\section{CHAPTER XIV.}

\section{FIRST MEETING OF DIRECTORS.}

\section{§ 127. Preliminary.}

As the by-laws are usually adopted prior to the election of the directors, these latter when elected will have the by-laws for their guidance. Their first meeting is merely a called meeting for special purposes,$i$. e., the election of officers and such other action as may be necessary in this early stage of the company's affairs. It may therefore very properly be assembled under the by-law provisions for special meetings of the board. Usually, however, and most simply, it is convened, as in the case of the stockholders' first meeting, by all entitled to be present joining in a call and waiver of notice. (See Form I8.) When all are agreed as to the matters to be transacted at this first meeting the minutes may with propriety be written out in advance. They will then serve as a program of the meeting and may usually be followed to the letter.

\section{§ 128. Opening the Meeting.}

When the directors assemble at the appointed time 
and place for their first meeting, they have as yet no officers. They will, therefore, choose a presiding officer pro tem and he will appoint, or the meeting will choose a temporary secretary. A director can not be represented by proxy at a board meeting (See § 66) and the secretary will therefore only note the number and names of those in actual personal attendance. If a quorum is shown to be present the chairman will then ask for the call and waiver, or other call or notice by which the meeting was assembled, and will direct, or motion will be made, that it be entered in the minutes, or that record be made of its due execution and service, or publication as the case may be. The meeting is then ready to proceed to the next order of business. This is usually the election of officers.

\section{$\S$ 129. Election of Officers.}

The by-laws should contain full provisions as to the officers to be elected and the method of choosing them. Usually the election is by ballot, though if all present agree to waive this requirement any other suitable method is permissible. Where there is but one candidate for an office the secretary will frequently be instructed to cast the single ballot of the meeting for the person named. Two positions, if their duties are not incompatible, may be conferred upon one person. The offices of secretary and treasurer are often filled by one individual, but it would always be awkward and in some states legally impossible for one person to be both president and secre- 
tary. The salaries of officers are usually arranged at or before the time of election. If they are to receive no compensation it should be so stated in the by-laws, or by means of a resolution, or be put upon record in some other way to avoid any subsequent misunderstandings.

As soon as the result of the election of officers has been announced, the newly-elected president and secretary, if present, will usually take charge of the meeting. If they are absent, or if other causes prevent the immediate assumption of their official duties, the temporary officers will continue to act until the close of the meeting, unless sooner relieved by the permanent officers.

\section{§ I30. Exchange of Property for Stock.}

The consideration of the proposal for exchange of property for stock usually follows the election of officers. The proposal submitted and read to the first meeting of stockholders and the stockholders' resolution authorizing its acceptance (Forms I9 and 20) should be presented to the meeting and read in full. Unless already recorded in the minutes of the stockholders' meeting the proposal should be ordered spread upon the minutes. (See Form 22.) Then a resolution accepting the proposed exchange and directing the officers of the company to receive the transfers of the property and to issue the necessary stock in exchange therefor is adopted. (See Form 2I.) This places the matter in the hands of the officers of the company with full power for its consummation 
and no further action on the part of the board is usually necessary.

\section{$\S$ I31. Designation of Bank.}

The election of officers and the acceptance of the proposal for exchange of property for stock are usually the most important matters coming before the first meeting of the directors. Its further action is mainly directed to such details as are necessary for the proper operation of the corporate business. Those relating to the corporate finances are among the more important of these.

It is most desirable that the financial operations of the new corporation should be begun and be conducted in a business-like manner. All moneys coming in should be promptly deposited in a designated bank in the name of the company. No money should be withdrawn save as authorized by the directors, and the actual withdrawal should be only by check, duly signed and countersigned by the proper officials.

The by-laws adopted by the stockholders at their first meeting usually provide in detail for the deposit and withdrawal of the company's funds, but leave the selection of the depositary to the directors. Accordingly a formal resolution is adopted at this first meeting of directors, designating the bank or banks in which the funds of the company are to be kept and providing any other necessary details as to the handling and management of the corporate moneys.

A copy of this resolution, duly certified by the secretary, should be prepared and be filed with the se- 
lected bank at the time the account is opened. (See Form 52.) If the directors' resolution does not embody the provisions of the by-laws relating to bank deposits, a certified copy of the by-laws, or of the particular by-law or by-laws in point, should also be prepared and filed with the resolution. (See Form I5.)

Usually provision will have been made in advance to supply the new company with funds, by stock subscriptions already secured, by sales of stock or through other means. Whatever the plan the board will take action at this time to make the arrangements effective.

\section{$\S$ 132. Other Business.}

Sundry other matters will properly come before the first meeting of the board. Arrangements must be made for office accommodation. Specific authority must be given the officers if anything is to be done outside the usual routine of the corporate business. The expenses of incorporation, including the fees to the state, and the legal and incidental obligations incurred by those having charge of the matter, should be approved and ordered paid. A form of stock certificate should be chosen, or, if already selected, approved. The secretary should be directed to procure the books and stationery necessary for his work. Any other requisite supplies and equipment should be authorized. The bond of the treasurer, if this is required and is presented in acceptable form, should be approved. In some states inspectors for the next 
annual election of directors must be chosen. If reports must be made or if there are other statutory requirements to be complied with, either in the state of domicile or in the state where the corporation expects to do business, proper provision should be made. In short all those matters should be attended to that are necessary to begin or facilitate the operations of the company.

\section{§ I33. Adjournment.}

It frequently happens that business under consideration at the first meeting of the board can not be completed at its session, or that other matters requiring board action are likely to come up before the next regular meeting. In such case to save the trouble and formality of calling a special meeting for the consideration of these matters, the meeting is adjourned till the next day, or the next week, or other convenient designated time. Then, as a continuation of the original meeting, it reassembles without formality and resumes its work. If desirable it may again adjourn to meet at some specified future date. Usually the only object of such continued adjournment is to save the formality and delay attendant upon the calling of special meetings.

If an adjourned meeting does not reassemble at the appointed time and place, it lapses and can not be revived. Then if a meeting be necessary before the date of the next regular meeting, it must be convened as a special meeting in accordance with the requirements of the by-laws. 


\section{CHAPTER XV.}

\section{PROTECTION OF MINORITY.}

\section{§ I34. General.}

The rights of the smaller, or minority, stockholders of a corporation are somewhat scant. They are entitled to an honest and efficient administration of the corporate affairs. They are entitled to such publicity of management as will enable them to judge whether the corporate affairs are so administered. Also they are entitled to such knowledge of the actions and intentions of the majority as will give them time and opportunity to avert or avoid any threatened action injurious to their interests. This is practically the measure of the minority's rights. They may neither dictate nor interfere in the corporate management in any way, save for the direct protection of threatened interests.

While the rights of the minority are few, it is of vital importance that these few be properly protected. This is best provided for when the arrangements for incorporation are in progress. At that time all concerned are usually ready to accede to any fair and reasonable demands. If those who will be in the 
minority are then in evidence and know how their interests may be protected, they may usually secure any proper concessions. If not provided for at this time efficient protection can hardly be secured later.

Unfortunately in many cases corporations are organized by those who expect to control and the rights of the minority receive small attention or are entirely ignored. In such event the only safe course for the minority is the sale of their stock. Better still, the unpleasant and usually unprofitable situation may be avoided entirely by a refusal to purchase stock in corporations which show so little regard for minority rights. If this latter course were more commonly pursued the rights of the minority would receive far more respectful attention than is now the case, and the status of the smaller stockholders would be much improved.

When, however, the prospective minority interests are in evidence and in a position to enforce their due rights at the time of incorporation, or when those in charge are willing to include proper protection of the minority in the general corporate scheme, the matter resolves itself into a choice of means. There are a number of methods employed for the protection of the minority. Most of these are founded upon representation upon the board of directors. Practice has shown that this is usually the most effective method possible.

The board is the managing body of the corporation. All active direction of the corporate affairs for 
good or for bad emanates therefrom. If then the minority have one or more capable representatives in this body these representatives are in a position to know all that is done, or proposed to be done, and to be heard in regard thereto. Their mere presence will usually operate to prevent any flagrant invasion of minority rights. If, however, injurious action is threatened, the minority stockholders will be informed and may act with all necessary promptness in protection of their interests. Through their representatives on the board they will at all times have access to the corporate books and accounts, and, generally, are in a position to enforce their rights intelligently and effectively should the necessity arise. Experience has shown that the minority have small cause for apprehension if they have one or more able representatives on the board.

\section{§ I35. Cumulative Voting.}

Cumulative voting is one of the simplest and most effective means whereby minority representation on the board may be secured. It is a modification of the usual plan of voting whereby the minority interestsif their holdings are at all material-may unfailingly elect one or more board members.

Under the usual plan of voting, each share of stock has one vote for every director to be elected, but may only give one of these votes to a candidate. As a consequence the majority elect the entire board, and, unless by grace of those in control, the minority are 
left absolutely without representation. Under the cumulative system each share of stock still has one vote for each director to be elected, but these votes may be cast all for one candidate or may be distributed among the candidates as the voter sees fit. In other words each stockholder has the right to cast as many votes as shall equal the number of his shares of stock multiplied by the number of directors to be elected, and to cast this number of votes for one candidate or distribute them among a number of candidates at his discretion.

For instance, if five directors are to be elected, each share has one vote for each of these or five votes in all. Under the ordinary system but one of these votes can be cast for one person, and if the five votes are cast they must be divided among five candidates, one vote to each. Under the cumulative system the number of votes is the same, but they may be cast exactly as the voter pleases. The whole five may go to one candidate or be divided between two, or be scattered among them all in such way as the voter sees fit.

If then one hundred shares of stock participated in such an election, a total of five hundred votes would be cast. A minority controlling twenty shares and acting together would cast one hundred votes, and, if all these were cast for one candidate, he would infallibly be elected. The remaining eighty shares would cast four hundred votes, and, if acting together, would elect four directors, but they could not 
by any possible combination prevent the minority from electing the fifth. If the majority divided their votes among four candidates, each would receive one hundred votes and all would be elected, together with the minority candidate who also receives one hundred votes. If they divided their votes among five or more candidates the total for each would fall below one hundred votes, and, while they would probably elect four of their candidates, the minority candidate would also be elected as before.

It is apparent that to secure the greatest advantage from cumulative voting those forming the minority must act together with intelligence and must so cast their votes as to secure the best possible results. If they do not, the whole benefit of the system may be lost to them. Thus in the preceding example if the minority divided their votes between two candidates, giving fifty shares to each, the majority might apportion their votes among five candidates, and giving eighty votes to each, elect the entire five and thereby exclude the minority from the board.

On the other hand it is also necessary for the majority to vote with discretion. If the minority are strong and well handled it is entirely possible for the majority by a careless scattering of their votes to actually lose their control of the board.

Cumulative voting is allowed in most states of the Union. In some it is prescribed by statute and must be employed in all corporate elections. The system is much esteemed where understood and its use is extending. (See $\S \S 56$, I I2.) 


\section{§ 136. Non-Voting Stock.}

Stock deprived of its voting power may be used to advantage when the parties to an incorporation, though of varying interests, wish to preserve an equality of power in the management. The occasion frequently arises in the incorporation of a partnership when the partners with smaller investments become minority stockholders, and, under the usual arrangement, would be largely, if not entirely, excluded from the management of their own affairs.

In this case the same equality of management in the corporation that obtained in the partnership may be preserved only by equal representation on the board. Cumulative voting insures representation, but not equal representation and therefore does not in itself meet the requirements of the present case. The desired end may be attained by the use of non-voting stock. To accomplish this the company's stock is divided into two classes, one a voting stock, the other non-voting, the amount of each class depending on the particular conditions. The voting stock is then apportioned equally among the parties interested, while the non-voting stock is so distributed as to provide for the varying interests of the different participants. As a result all the parties are exactly equal in voting power and therefore if coupled with cumulative voting are equal in the management of the corporation. In any division of profits, however, as the non-voting stock participates in dividends just 
as does the voting stock, the parties with the larger interests receive properly the larger returns.

This arrangement is very effective and may be modified in sundry ways to protect or give special rights to the minority. (See $\S$ I45.)

\section{§ I37. Stock Classification.}

In those states in which it is permitted, another method of providing equal, or special representation on the board of directors is found in the division of the corporate stock into voting classes or groups, usually unequal in size, but each possessing the power to elect one or more members of the board.

For instance, if a partnership with three members is to be incorporated, and, while the investments are different, the management is to be shared equally, a board of three directors might be provided. If so, the capital stock is then fixed at the total amount of the partnership assets and is divided into three classes or groups, the classes varying in amount so that each represents the interest of one of the partners in the business. Each class is by charter provision given power-irrespective of its amount-to elect one director. Each partner then receives the entire amount of the class of stock which represents his interest. When this is done each partner, while holding his proper interest in the corporation, and participating in profits accordingly, elects one director and has therefore equal power in the management. He may elect himself a director, or elect someone else to rep- 
resent him. Further he may sell any amount of his stock short of the fifty-one per cent. required to control his class, and still retain his power to elect one director.

This system of classification is a very efficient means of minority protection. In those states where permitted, it is worked out in many forms. (See $\S$ I45.) It should, however, be carefully considered before it is employed, as the arrangement, once adopted, is difficult to change and occasionally leads to undesirable complications.

\section{$\S$ I38. Voting Trusts.}

The voting trust is an arrangement or disposition of the majority of the voting stock of a corporation under which for a definite period its vote must be cast in its entirety for certain specified ends. Its usual purpose is to maintain the existing, or an agreed management for a term of years. So used it may serve as an efficient means for the protection of the minority.

In the early days of an incorporation all parties in interest are usually disposed to be fair. A management acceptable to both majority' and minority may then be obtained. If the majority concur, this management may be fixed for a specified period by means of the voting trust, thus avoiding changes which might be injurious to minority interests.

To form a voting trust, sufficient stock to control must be actually placed in the hands of voting trus- 
tees. This stock is held by them under the terms of a voting trust agreement which specifies how its vote must be cast, and this vote may then be cast only in accordance with these specifications. The operation of a properly drawn agreement is absolute. If it provides that at elections of directors the vote of this stock shall be cast for certain specified persons, those persons will be elected unfailingly and the membership of the board preserved unchanged during the life of the agreement. Provision is usually made for possible vacancies caused by the death, inability or refusal to serve of any of the designated directors. Also the trustees are usually given authority to vote the trust stock held by them, on any general matters coming before the stockholders for their action. The trustees usually issue trustees' certificates for the stock placed in their hands under the trust agreement, and they must account to the equitable owners of this stock for any dividends declared thereon during the continuance of the trust.

Voting trusts are allowable under the laws of most of the states. In New York and some other states their period is limited to five years. In most of the other states they would be upheld if the agreement was for a reasonable period.

\section{$\S$ I39. Limitations on Expenditures.}

Limitations are sometimes inserted in the charter in the interests of the minority, providing that the salaries of officers shall be some certain amount, or 
shall not exceed a specified sum save with the consent of two-thirds of the voting stock, or shall be limited to some moderate prescribed figure until dividends have been paid regularly at a certain per centum for one or more years. Or it is sometimes specified that no indebtedness beyond a given proportion of the appraised value of the assets shall be incurred without the consent of a specified majority of the stock.

Under some circumstances these restrictions and the sundry other variations of which they are capable are found to be materially advantageous. Such limitations should not, however, be so tightly drawn as to restrict the proper corporate action of the company or interfere with its successful business operation. (See $\S$ II 5 .)

\section{$\S$ I40. Restrictions on Amendments.}

Sometimes as a means of minority protection it is provided in the certificate of incorporation that a specified majority shall be required for the election of directors. At times the provision will be extended to also include amendment of the charter and by-laws. These majorities are placed high enough to require the participation of a material proportion of the minority interests and the requirement therefore acts directly for their protection. Then an acceptable board of directors having been once selected, no change of any kind can be made in the management thereafter without the assent of the prescribed majorities of the outstanding stock. 
For example, the charter of the American Tobacco Company contained the following provision:

"It is hereby provided that it shall require a majority of seventy-five per cent. of the outstanding voting stock to amend the charter, to amend the by-laws, or to elect directors in this company."

It is a fair inference that when the American Tobacco Company was organized, a strong minority interest would enter only on condition that the provision quoted was incorporated in the charter of the company, and that this charter and the by-laws and the first board of directors, should be satisfactory to them.

When all this was accomplished there could be no change in the existing state of affairs without the consent of the minority interests, provided they controlled at least 26 per cent, of the voting stock. If a new board were proposed they might merely refrain from voting; there would then be no election and the old board would hold over. Neither could there be any change in charter or by-laws not approved by them. Under such conditions the minority were undoubtedly in a position to fully protect their interests. It should be noted, however, that the arrangement is allowable under the statutes in only a few states.

\section{§ I4I. Restrictions on the Voting Power.}

Under the English Companies Act, which controls in England, every stockholder has one vote for each 
share of his stock up to ten. If he holds more than ten shares he has one vote for each five shares above that number up to one hundred shares. Above that number he has one vote for each ten shares he may hold.

As will be seen this has the effect of materially lessening the power of the larger stockholders. The arrangement, or any desired modification of it, might be had under the New Jersey law and probably in some other states of the Union, but the plan is not generally available. It is undoubtedly effective but would probably render an election of directors a complicated proceeding. 


\section{CHAPTER XVI.}

\section{FROM PARTNERSHIP TO CORPORATION.}

\section{§ I42. General.}

The conversion of a partnership into a corporation under the usual plan is a comparatively simple matter, accomplished without interruption to the general business and without material change in its mode of operation. Almost any feature that characterized the partnership may be continued in the corporation. Even the name may usually remain unchanged. The legal relations and liabilities of the members of the organization are modified, but the general method of work and the personal relations and responsibilities of its members may for all practical purposes be left unaltered.

Generally a partnership should be incorporated in the state in which its principal operations are conducted-that is, the state in which the headquarters of the firm have been located. Occasionally conditions will exist that render incorporation in another state advisable. In such case the corporation will operate in what would naturally have been its home 
state, as a foreign corporation. The advantages of such an arrangement should be obvious and material to justify its adoption. (See $\S$ ro6.)

The capitalization of the incorporated partnership is usually determined by the amount of the firm assets. A fair valuation of the business is made, in which good-will may be properly included, and the capital stock, or capitalization, is fixed at the amount so determined. Occasionally the capitalization is placed at an amount much less than the real value of the assets in order to avoid taxation.

\section{§ I43. Name.}

The partnership name should in itself represent a considerable trade value. To avoid its loss the partnership name on incorporation is usually retained in some form as the corporate name. In some states the firm name may be adopted without change of any kind. This practice is, however, open to objection as there is then nothing in the name to indicate that the concern is a corporation, and parties transacting business with it might, unless informed in advance of its corporate character, be able to hold the stockholders as partners.

Usually the firm name is retained with the addition of Company, the firm of "Wilson \& Brown" becoming on incorporation the "Wilson \& Brown Company," or perhaps the "Wilson-Brown Company." Another method of avoiding any possibility of liability is to add the word incorporated, as "Wilson 
\& Brown, Incorporated," this last word being abbreviated in written or printed matter to "Inc."

In most of the states the word "The" may be made part of the corporate name if desired. In a few states it is obligatory. Very awkward verbal constructions sometimes occur when it is employed.' (See $\S$ I02.)

\section{$\S$ I44. Usual Arrangements.}

When a partnership is incorporated the obvious and customary arrangement is to fix the corporate capitalization at the value of the partnership business. The entire capital stock is then issued to the partners as full-paid stock in exchange for the business, which is thereupon transferred to the new corporation. This general method of arranging the matter is the simplest possible and, where the partners' interests are equal, is equitable and satisfactory. The partners may have the stock issued in the firm name, or to one of the partners as trustee, later allotting it among themselves in proportion to their respective interests in the old firm, or may have it issued direct in proper proportion to themselves.

Sometimes in order to provide working capital for the corporate business, the capital stock is placed at a figure in excess of the assets, the excess stock is sold and the proceeds turned into the treasury of the company. If the equality of voting power among the partners is to be preserved and this additional stock is a voting stock, it might either be purchased by the partners in agreed proportion, or each partner might be assigned his proportion to sell among his 
friends. If it is sold to outsiders, this additional stock under such circumstances would usually be a non-voting stock-probably some form of preferred stock. (See $\S \S 39$, I36.)

\section{$\S$ I45. Special Adjustments.}

Where the partnership interests are not equal, the apportionment of stock in the incorporated business in direct proportion to these interests without adjustment of any kind would sometimes work great injustice. For instance, one partner may have supplied the larger proportion of capital, but the other partner-if there be but two-may have contributed more time, or such skill, repute, business knowledge, or connection as to fully entitle him to an equal share in the business, or otherwise to such control, or proportion of the profits, or other advantageous arrangement as may have existed under the partnership agreement. In such case to give the greater financial interest absolute control by an allotment of a majority of the voting stock would be obviously inequitable.

Such a contingency may be easily provided for under the flexible conditions of incorporation. Equality of management may be preserved by the issuance to each partner of an equal amount of voting stock. The larger investment of the one may then be provided for by an issue to him of non-voting stock to the amount of his excess investment. This stock might participate fully in dividends, but usually would be a preferred stock drawing a fixed limited dividend. 
Under such an arrangement both partners are on the same footing as far as the control of the corporation is concerned, and in all other corporate matters, except that before any division of profits is made the partner with the larger investment receives the agreed interest or return on his excess investment; also, if his extra stock be preferred, this usually gives him the right to receive back his excess investment in full in case of dissolution before the other partner receives anything. (See $\S 53$.)

The same end might be attained by the issuance of bonds for the excess investment of any partner. Another plan is to divide the stock into as many classes as there are partners, each class representing in value the investment of the partner to whom it is allotted, but-without regard to this value-having the right to elect one director. If then the board of directors is the same in number as the partners of the incorporated firm, this secures an absolute equality of management regardless of the differing investments. (See $\S \S$ I II, I37.) The same end will sometimes be secured by the formation of a voting trust. (See $\S$ I38.) Special official salaries are also sometimes employed to adjust the varying interests of the incorporated partnership. In short there is no legitimate arrangement of the partnership which can not be transformed into some equivalent, or equally satisfactory corporate arrangement.

\section{$\S$ I46. Preliminary Contract.}

Any special features of the partnership interests 
and relations that are to be retained in the new organization, should be embodied in a preliminary contract between the partners. Even if the usual arrangements are to prevail, a memorandum of the agreement is frequently advantageous.

It is to be noted that the charter and by-laws are supposed to contain and usually do contain everything outside the statute and common law that affects the new company. Therefore, any agreements and understandings between the interested parties as to the powers of stock and the general management of the corporation must be expressed either in the charter or by-laws, and if not so expressed, are usually invalid or incapable of enforcement.

\section{$\S$ 147. Organization of Corporation.}

If the number of partners is less than the smallest number required by statute as incorporators, the services of relatives, friends or employees may be enlisted for the incorporation and these same parties may also later act as directors if desirable. In this latter event the usual statute requirement that directors must be owners of record of at least one share of the company's stock is commonly satisfied by those in control assigning one share to each of the acting parties. Such assigned stock is usually actually and permanently transferred as an equivalent for the time and trouble involved in a "dummy" directorship. At times, however, while given in due form, such stock is after proper assignment by the receiving party, at once taken back and held by the donor. The recip- 
ient then appears on the books of the company as the owner of record of such stock and is therefore legally qualified to act as a director. As a matter of fact, however, the actual ownership of the stock rests with the party to whom it was re-assigned, and he may at any time assert this ownership by presenting the assigned certificate and demanding that the stock it represents be placed in his own name. To do so would, however, disqualify the "dummy" director and necessitate some new arrangement of the directory.

Often the wives of the partners are brought into the corporation as incorporators and as directors and are, at times, made stockholders to considerable amounts. This is on occasion a most excellent arrangement. In case of the death of the husband it leaves the corporate holdings exactly where they should be, without danger of failure and without legal proceedings of any kind.

If the firm is incorporated in an outside state, a resident director is usually necessary. This prospective director also usually acts as one of the incorporators.

As a matter of course, the active partners of the firm are usually elected as directors and also as officers of the incorporated business. If the required number of directors be more than the number of partners, as where a partnership of two is incorporated and three directors are necessary, additional directors must be secured. Usually these are "dummy" direc- 
tors qualified as described for the purpose. Also if the partners are of even number, as two or four, they will probably wish additional directors to make the number of the board uneven. This is not essential but is customary to prevent the possibility of dead locks. At times, however, the even board may be preferred, any occasional dead locks being fought out as was done in the partnership.

If the partners are but two in number, and, upon the incorporation of the firm, wish the equality of power between them preserved, while the statutes require a board of three, a dummy director may be elected and then resign, his place being left unfilled. The two former partners then have full power to act for the corporation as they constitute a majority of the board. The only objection to the plan is found in the fact that the continued absence, disability or death of one of the directors would leave the board without a quorum and without power to fill the vacancy unless such power were expressly given by charter or by-laws. This would necessitate action by the stockholders to re-establish the board. Sometimes the third director is retained on the board, but it is provided that no important board action-or any board action-may be taken except by unanimous vote of the entire board. Then no action may be taken without the concurrence of the two former partners, and the equality of power in the management is maintained.

The arrangements indicated while entirely possi- 
ble and proper, and in common use, require the services of a thoroughly qualified and skilful lawyer as otherwise statute law may be inadvertently violated, or the corporation itself may be so tied up that the conduct of its business becomes impossible.

\section{$\S$ I48. Transfer of Business.}

As soon as the directors and officers of the new corporation have been elected and its organization is thus completed, it is ready to take over the business and property of the old firm and assume full control. At their first meeting the stockholders pass a resolution in accordance with the agreement previously entered into by the partners, authorizing and instructing the directors to purchase the partnership property and business and issue the stock of the corporation in exchange therefor. The directors at their first meeting in pursuance of the stockholders' resolution then formally accept the proposition to take over the business and property of the firm, and authorize the officers to receive the same and issue the stock of the corporation in payment therefor in accordance with the accepted terms. (See Chs. XIII, XIv; also Forms 19, 20, 21.)

By due assignment of the firm the business is then transferred to the corporation. Usually the assignment includes all goods and other stock, cash on hand and in bank, accounts and bills receivable, real estate, leases, fixtures, patents, trade-marks, goodwill and anything else of value belonging to the firm. Any desired reservations, however, may be made, as for instance the cash on hand, or certain accounts, 
or particular real estate. Usually it is specified that all debts, contracts and liabilities of the firm are to be assumed by the new corporation.

These assignments are executed in the firm name by the partners and are handed over to the officers of the corporation. These latter then deliver in exchange the duly issued stock of the corporation in accordance with the agreed terms. This transaction makes the stock full-paid. It also vests the business and property of the former partnership in the corporation. The officers of the company then take charge of the business and the transaction is complete. The business is the same as it was before and is in the hands of the same persons, but the liabilities and method of operation are from the legal standpoint entirely different.

After its stock in the new corporation has been received and distributed among the partners, the old firm is usually dissolved.

\section{$\S$ I49. Conduct of Business Under New Form.}

After incorporation the business of the former partnership is usually conducted much as before, especially if there were but two or three partners and all were actively engaged in the business. Usually after the organization meetings, the former partners-as officers and directors-take entire charge of the corporate business and manage it as they did before its incorporation by informal conferences and mutual agreement as occasion arises. This laxity of corporate management may be carried too far, but where 
the officers and directors constitute all the parties in interest and all are agreed, there is but little danger from the informality of the method. The treasurer should, however, handle the funds of the corporation and perform his other duties in strict accordance with the by-laws and the resolutions of the board of directors.

A corporation of this kind where no stock is sold to outsiders, where but few are interested and where those few are, in the main, either officers or directors, is called a "close corporation." Such a company rarely takes the trouble to hold annual meetings unless some dissatisfaction, or other cause makes a change in the directory advisable. Otherwise the directors and officers hold over from one year to another, and until one of the parties active in the management dies or retires, no changes are made. When such an emergency does arise the advantages of the corporate form are manifest. Its neglected formalities are then at once brought into play and the corporate mechanism is readily adjusted to the changed conditions.

\section{$\S$ I50. Changing Books.}

Though not strictly relevant, it may be said that the changing of the partnership books to corporation books is usually a matter of no great difficulty. The capital or stock account is kept in the corporate name thereafter, and the individual accounts with the partners are closed. 
"The only new features introduced into the books of account when a private or partnership business is transferred to a corporation are those which relate directly to the mechanism of the corporate form. Thus the interests of the parties forming the corporation are represented by stock and a 'Capital Stock' account is necessary. Profits when divided are declared as dividends and a 'Dividend' account must be opened. Stock returning to the corporation either by purchase or by donation becomes treasury stock and a 'Treasury Stock' account is required. The corporate losses or gains find their ultimate resting place in a 'Surplus' account. Bonds when issued re-' quire a 'Bond' account, and accounts must also be kept with the interest on these bonds as it accrues from month to month."*

New books though usual are not at all necessary when the partnership accounts are transferred to the corporation. "If the partnership books are to be continued as the corporate books when a partnership is incorporated, the procedure is simple. The accounts of the partnership books are balanced, those showing loss or gain are closed into 'Profit and Loss' account, and this account is then charged off to the individual accounts of the partners. The capital stock of the corporation is then so issued as to close these partnership accounts." $\dagger$

* Bentley on "Corporate Finance and Accounting," page at 5.

† Bentley on "Corporate Finance and Accounting," page 233. 


\title{
PART IV.-CORPORATE FORMS.
}

\author{
CHAPTER XVII. \\ SUBSCRIPTION LISTS.
}

Form I.-Subscription List. Usual Form.

SUBSCRIPTION LIST.

THE VERASCOPE CAMERA COMPANY.

To be Incorporated under the Laws of New .York.

$$
\begin{gathered}
\text { Capital Stock.........\$25,000. } \\
\text { Shares....\$100 each. }
\end{gathered}
$$

We, the undersigned, hereby severally subscribe for and agree to take, at its par value, the number of shares of the Capital Stock of the Verascope Camera Company set opposite our respective names, and agree to pay therefor in cash on demand of the Treasurer as soon as said Company is organized.

\begin{tabular}{|c|c|c|c|}
\hline NAMES. & ADDRESSES. & SHARES. & AMOUNT. \\
\hline $\begin{array}{l}\text { David B. Ewbank.... } \\
\text { Henry Brown.......... }\end{array}$ & $\begin{array}{l}\text { Troy, New York...... } \\
\text { Syracuse, New York }\end{array}$ & $\begin{array}{l}15 \\
\text { IO }\end{array}$ & $\begin{array}{r}\$ \mathrm{I}, 50000 \\
\mathrm{I}, 00000\end{array}$ \\
\hline
\end{tabular}

Troy, N. Y., September 20, 1909.

This is the simplest form possible. It will be found sufficient for small corporations where the purposes I 78 
and conditions of subscription are well understood. All the essential features of the proposed company should be incorporated in the subscription list and no material change should be made later, otherwise the subscriptions may be voided. Subscribers must be persons competent to contract. In event of litigation the courts construe subscription lists liberally and in accordance with their intent. (See $\S$ 4I, 99.)

It should be remembered that subscriptions under such a list are-until the organization of the corporation-mere promises without consideration and therefore revokable by the subscriber. To avoid this element of uncertainty subscription lists are sometimes drawn with a trustee acting for the proposed corporation, so that subscriptions thereunder are binding as soon as made. The following form is of this nature.

Form 2.-Subscription List. Trustee's.

SUbSCRIPTION List. HARVEY BRASS COMPANY.

To be Incorporated under the Laws of New York for the Manufacture of Brass and Metal Ware.

Capital Stock......... \$200,000.

Shares..... \$100 each.

We, the undersigned, hereby severally subscribe at par for the number of shares of the capital stock of the Harvey Brass Company set opposite our respective signatures, and hereby promise and agree to pay therefor as follows:

Five (5\%) Per Cent. of subscription on demand to Henry M. Shannon, as Trustee for the said Company, such payment, or 
so much thereof as may be necessary, to be used for the preliminary and incorporating expenses of said Company; Thirty (30\%) Per Cent. of subscription to the Treasurer of the Company ten days after the incorporation thereof, and the remainder of subscription at such times and in such instalments as may be prescribed by the Board of Directors.

New York, July I6, rgog.

\begin{tabular}{c|c|c|c}
\hline \hline NAMES. & ADDRESSES. & SHARES & AMOUNT \\
\hline Willoughby Knight.. & 32 Nassau St., N. Y. & 25 & $\$ 2,500$ o0 \\
\hline
\end{tabular}

\section{Form 3.-Subscription Blank. Individual.}

SubSCRIPTION Blank.

THE NEW ALBANY RUBBER COMPANY.

60 Liberty St., New York.

To be Incorporated under the Laws of New Jersey.

Capital Stock.........\$500,000.

Shares.....\$100 each.

I hereby subscribe for Twenty-five (25) shares of the Capital Stock of The New Albany Rubber Company at the par value thereof, and agree to pay Fifty ' $(50 \%)$ Per Cent. of such subscription on demand of the Treasurer so soon as said Company is incorporated; the remainder to be paid at such times and in such amounts, not exceeding Ten ( 10 \%) Per Cent. of said subscription in any one month, as may be prescribed by the Board of Directors.

Unless one-half the capital stock of said Company is reliably subscribed by the 30th day of December, 1909, and the Company incorporated within thirty days thereafter, this subscription shall be void and of no effect.

Name, Henry McConnell, Address, 1763 Chestnut St.,

Dated Sept. 15, 1909. Philadelphia, Pa. 
The above form is usually mailed, accompanied by such statement, prospectuses and explanations as may be necessary. Any material misstatement of fact in the subscription blank or the accompanying papers renders the subscription void at the option of the subscriber.

The same general form of blank is frequently employed when stock is to be sold after incorporation, such modifications being made as are necessary to adapt it to the changed conditions. 


\section{CHAPTER XVIII.}

\section{STOCK CERTIFICATES.}

As a rule the stock certificates in common use contain all the essential requirements, differing only in the arrangement of matter, manner of expression, etc. The legality of a certificate of stock is not affected in any way by the style in which it is prepared. One written with pen and ink is as legally effective as the finest engraved certificate. From a business standpoint, however, certificates should be neat and tasteful and of reasonably good quality. The stock exchanges require a certain prescribed excellence of finish in the certificates of stock which are listed with them.

Usually the officers to sign stock certificates are designated by the by-laws of the corporation, though in some states, as New Jersey, the signing officials are designated by the statutes.

The words "full-paid and non-assessable" should not appear upon certificates unless the stock which they represent has really been paid for in full, in cash or in property. (See generally $\S \S 42$, I I9.) 
: $\frac{\dot{d}}{\text { : }}$

요

z

资

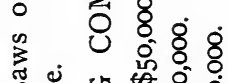

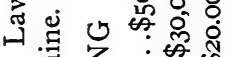

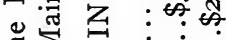

포

兽出

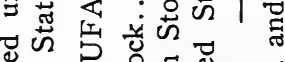

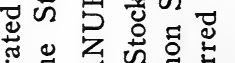

芯导芯芯总

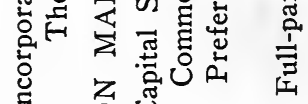

录

官:

15

영

वं

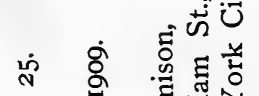
- 元急穴

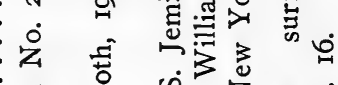

- य 인

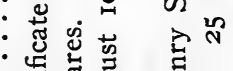

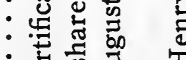

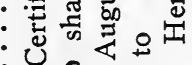

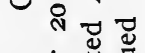

䒘芯芯

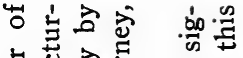

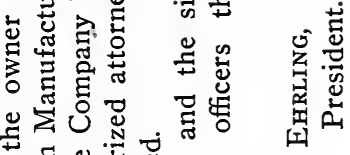

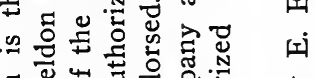

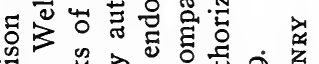

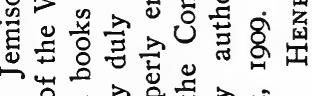

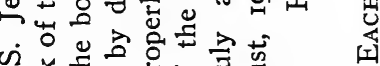

듕ㅎㄷ

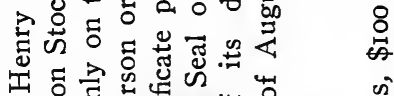

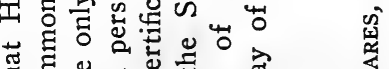

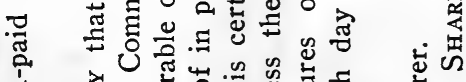

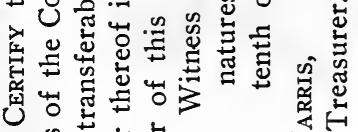

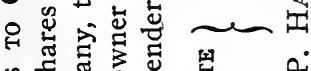

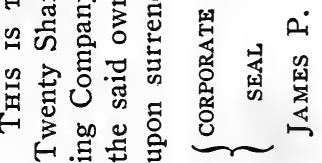




\section{Form 5.-Preferred Stock Certificate.}

No. 15.

Io Shares.

Incorporated under the Laws of

The State of Maine.

WELDON MANUFACTURING COMPANY.

Capital Stock.........\$50,000.

Common Stock..... \$30,000.

Preferred Stock.... \$20,000.

Full-paid and Non-assessable.

This is to Certify that James H. Wilson is the owner of Ten Shares of the Preferred Stock of the Weldon Manufacturing Company, transferable only on the books of the Company by the said owner, in person or by duly authorized attorney, upon surrender of this Certificate properly endorsed.

The preferred stock represented by this certificate is entitled to an annual dividend of Six $(6 \%)$ Per Cent. payable out of the net profits of the Company before any dividend is paid upon the Common Stock. Should the net profits in any year be insufficient to pay said preferred dividend, either in whole or in part, any unpaid portion thereof shall become a charge against the net profits of the Company and shall be paid in full out of said net profits before any dividends are paid upon the Common Stock.

Said preferred stock is subject to redemption at the option of the Company at any time after Ten (ro) Years from the first day of August, 1909, either by payment of One Hundred and Five (\$105) Dollars per share and any accumulated dividends, or if so elected by the Company, by exchange therefor of common stock of the Company, at the rate of four shares of said common stock for each three shares of preferred stock so redeemed, any preferred stock redeemed under this provision to be cancelled and not thereafter to be reissued.

Said preferred stock is not entitled to vote at stockholders' 
meetings of the Company, nor to participate in profits beyond its fixed, preferential, cumulative, annual dividend of Six Per Cent. (CORPORATE) Witness the Seal of The Company and the sig$\left\{\begin{array}{c}\text { CORPORATE } \\ \text { SEAL }\end{array}\right\}$ natures of its duly authorized Officers this JAMES P. HARRIS,

Treasurer.

Henry E. Ehrling,

\section{Shares \$IOO EACH.}

(Stub same as for Common Stock except that heading should read "Preferred Stock." This requirement is, however, quite commonly neglected.)

The conditions under which preferred stock is issued should appear upon its face, as in the above form. (See $\S 89$. )

Form 6.-Assignment of Stock Certificate. In Blank.

For Value Received....hereby sell, assign and transfer unto of the Capital Stock represented by the within Certificate, and do hereby irrevocably constitute and appoint................, my Attorney to transfer the said stock on the books of the withinnamed Company, with full power of substitution in the premises.

William Clephane.

Dated...............

In presence of :

Jere H. McLain.

This form of assignment appears upon the back of the stock certificate. It is the only form in common use. The signature when a transfer is to be made must correspond exactly with the name upon the face of the certificate. 
If this assignment is duly signed by the owner of the stock and this signature properly witnessed, but the names of the party to whom the transfer is made and of the attorney are omitted as in the preceding form, the assignment is said to be made in blank. The certificate may then be sold and passed from hand to hand without further assignment until some purchaser wishes to make himself a holder of record. The blanks in the assignment are then filled in as shown in the following form, the certificate surrendered and a new certificate taken out in the name of the owner of the stock. (See $\S 44$.)

Usually the name of the secretary of the company is inserted as the attorney who is to make the transfer on the books of the company, though any other suitable person might be named instead.

Form 7.-Assignment of Stock Certificate. Complete.

For Value Received, I hereby sell, assign and transfer unto Wilson Montgomery of New York City, Twenty-five (25) Shares of the Capital Stock represented by the within Certificate, and do hereby irrevocably constitute and appoint Samuel H. Colesworth, my Attorney to transfer the said stock on the books of the withinnamed Company, with full power of substitution in the premises.

William Clephane.

Dated September I, I909.

In presence of:

Jere H. McLain. 


\section{CHAPTER XIX.}

\section{CHARTER FORMS AND STATE FEES.}

Charter forms vary in the different states in accordance with the varying statute requirements, though the general requisites of the charter are much the same in all. The following charter applications-or charters as they become after allowance-show the forms in use in New York, New Jersey and Arizona. The forms presented are simple, but, within their scope, are clear and complete and serve to give an idea of the usual charter form. They are included in order to render intelligible the many references in the present volume to the charter and its requirements.

It is to be noted that the charter is in form merely an application for a charter. If properly drawn and duly presented with payment of the required fees, the charter application is allowed and filed as a matter of course. It thereupon immediately becomes the charter of the new corporation and this latter is then fully authorized to perfect the corporate organization and proceed with its business. (See Ch. III and $\S$ IOO.) 


\section{Form 8.-New York Charter.}

\section{Certificate of Incorporation}

of the

\section{LEDOUX MANUFACTURING COMPANY.}

We, the undersigned, all being of full age and two-thirds being citizens of the United States, and one of us a resident of the State of New York, for the purpose of forming a Corporation under the Business Corporations Law of the State of New York, do hereby certify and set forth:

First-The name of said Corporation shall be

\section{"Ledoux Manufacturing Company."}

Second-The purposes for which said Corporation is formed are as follows:

I. To buy, sell, manufacture and generally deal in all manner of tools, machinery, devices, appliances and supplies as used in wagon making and the allied trades.

2. To lease, buy, sell, use and hold all such property, real or personal, as may be necessary or convenient in connection with the said business.

3. To do any or all things set forth in this certificate as objects, purposes, powers or otherwise, to the same extent and as fully as natural persons might do, and in any part of the world.

Third-The amount of Capital Stock of said Corporation shall be Fifty Thousand Dollars $(\$ 50,000)$.

Fourth-The number of shares composing said capital stock shall be Five Hundred (500) Shares of the par value of One Hundred Dollars ( $\$ 100$ ) each, and the amount of capital with which said Corporation will begin business is Five Hundred Dollars ' $(\$ 500)$.

Fifth-The principal business office of said Corporation shall be 
in the Borough of Manhattan, in the City, County and State of New York.

Sixth-The duration of said Corporation shall be perpetual.

Seventh-The number of directors of said Corporation shall be three.

Eighth-The names and post-office addresses of the directors of said Corporation for the first year are as follows: NAMES.

ADDRESSES.

Henry Willis Ledoux........25 Liberty St., New York City. Henry B. Divine...........30 Broadway, New York City. Manley Scolwood...........68 Montague St., Brooklyn, N. Y.

Ninth-The names and post-office addresses of the subscribers to this certificate, and the number of shares of stock which each agrees to take in said Corporation, are as follows:

NAMES.

ADDRESSES.

SHARES.

Henry Willis Ledoux...25 Liberty St., New York City..... 20 Henry B. Devine.......30 Broadway, New York City..... I5 Manley Scolwood......68 Montague St., Brooklyn, N. Y... I5 Sarah H. Adams.....7 to Lexington Ave., New York City to

Tenth-Pursuant to Section 52 of the Stock Corporations Law, as amended, this Corporation shall have power to purchase, acquire, hold and dispose of the stocks, bonds and other evidences of indebtedness of any corporation, domestic or foreign, and issue in exchange therefor its stocks, bonds or other obligations.

In WitNess WihereoF, we have made and signed this certificate in duplicate this fourteenth day of August, one thousand nine hundred and nine.

Henry Willis Ledoux.

Henry B. Devine.

MANLEy Scolwood.

Sarah H. Adams.

$\left.\begin{array}{l}\text { State of New York, } \\ \text { County of New York, }\end{array}\right\}$ ss.:

Personally appeared before me this 14th day of August, 1909, Henry Willis Ledoux, Henry B. Devine, Manley Scolwood and Sarah H. Adams, to me personally known to be the persons 
described in and who executed the foregoing certificate, and severally acknowledged that they executed the same for the purposes therein set forth.

$$
\left\{\begin{array}{c}
\text { NOTARIAL } \\
\text { SEAL. }
\end{array}\right\}
$$

JAmes H. Scully, Notary Public for New York County.

\section{Form 9.-New Jersey Charter.}

\section{CERTIFICATE OF INCORPORATION of the}

CARHART DRUG COMPANY.

We, the undersigned, for the purpose of forming a corporation under and by virtue of the provisions of an act of the Legislature of the State of New Jersey, entitled "An act concerning corporations (Revision of $I 896), "$ and the several supplements thereto and acts amendatory thereof, do hereby severally subscribe for and agree to take the number of shares of stock of the said corporation hereinafter placed opposite our respective names, and do further certify and set forth as follows:

First-The name of said corporation shall be

\section{"Carhart Drug Company."}

Second-The location of its principal office in the State of New Jersey shall be at No. I5 Exchange Place, Jersey City.

The name of the agent who shall be therein and in charge thereof, upon whom process against this corporation may be served, is the Corporation Trust Company of New Jersey.

Third-The objects for which this corporation is formed are:

(a) To manufacture, prepare, compound, mix, combine, buy, sell and generally deal in all manner of chemicals, chemical products, drugs and pharmaceutical compounds and preparations, and to patent, register or otherwise protect the same.

(b) To obtain, purchase or otherwise acquire formulæ, patents and secret processes for the manufacture and prepa- 
ration of chemicals, drugs and the compounds and preparations thereof and to operate under, sell, assign, grant licenses in respect of, or otherwise turn the same to account.

(c) To enter into, carry out or otherwise turn to account contracts of every kind; to have and maintain offices within and without the State; to acquire, hold, mortgage, lease and convey or otherwise use or dispose of real and personal property in any part of the world, and in general to carry on such operations and enterprises and to do all such things in connection therewith as may be permitted by the laws of New Jersey and be necessary or convenient in the conduct of the Company's business.

Fourth-The total authorized stock of the corporation shall be twenty-five thousand dollars $(\$ 25,000)$, divided into two hundred and fifty (250) shares of the par value of one hundred dollars $(\$ 100)$ each, and the amount of capital stock with which said corporation will begin business is five thousand dollars $(\$ 5,000)$.

Fifth-The names and post-office addresses of the incorporators and the number of shares subscribed for by each are as follows:

NAMES.

ADDRESSES.

SHARES.

Willis J. Carhart.....I5 Exchange Place, Jersey City, N. J... 40 Sheldon McCammis.... John B. Whelan.......

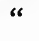

“

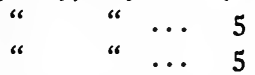

Sixth-The period of existence of said corporation shall be unlimited.

IN WitNesS Whereof, we have hereunto set our hands and seals this 21 st day of July, A. D. nineteen hundred and nine.

In the presence of:

$$
\begin{array}{ll}
\text { Willis J. Carhart. } & \text { [L. s.] } \\
\text { Sheldon McCammis. } & \text { [L. s.] } \\
\text { John B. Whelan. } & \text { [L. S.] }
\end{array}
$$

HARMON WATSON.

Thomas O'ConNell.

State of New Jersey,

County of Hudson, $\}$ ss.:

Be it remembered, that on this 2Ist day of July, A. D. nineteen hundred and nine, before the undersigned personally ap- 
peared Willis J. Carhart, Sheldon McCammis and John B. Whelan, who, I am satisfied, are the persons named in and who executed the foregoing certificate, and I, having first made known to them, and each of them, the contents thereof, they did each acknowledge that they signed, sealed and delivered the same as their voluntary act and deed.

$$
\begin{gathered}
\text { John M. Johnson, } \\
\text { Master in Chancery of New Jersey. }
\end{gathered}
$$

Such a certificate of incorporation must be personally signed and sealed by all the subscribers to the capital stock who are named in the instrument, and be then acknowledged by them before any officer qualified under the New Jersey laws to take acknowledgments for deeds of real estate.

\section{Form ro.-Arizona Charter.}

\section{Articles of INCORPORATION.}

Know All Men by These Fresents, That we, the undersigned, have this day associated ourselves together for the purpose of forming a corporation under and pursuant to the Laws of the Territory of Arizona, and for that purpose do hereby adopt Articles of Incorporation as follows:

\section{Article I.}

The name of the corporation shall be Andes Exploration and Development Company.

\section{Article II.}

The principal place of business of this corporation within the Territory of Arizona shall be at Phoenix, Maricopa County, and the principal place or places of transacting business outside of Arizona shall be at New York City, State of New York, where meetings of Stockholders and Directors may be held and all business transacted. 
Article III.

The general nature of the business proposed to be transacted is as follows:

I. Mining, smelting, refining, reducing and dealing in and with all sorts of ores, metals and minerals, and the prospecting, locating, opening, operating and developing of mines, oil wells, quarries and mineral deposits of all descriptions.

2. Constructing and operating mills, factories, machine shops and industrial plants of all descriptions, and the buying, selling and dealing in and with all supplies, merchandise and materials, raw or prepared, useful or convenient in connection therewith.

3. Establishing and conducting savings institutions, loan, trust and investment companies, and guarantee and insurance institutions, either directly or indirectly, in such form and manner as the laws may permit.

4. Farming, planting and tilling the soil and the operating of farms, ranches, orchards, plantations and haciendas, and all industries appurtenant thereto.

5. Constructing and operating tramroads, canals; irrigating systems, steamboats, steamships and ships and vessels of all kinds.

6. Buying, selling, leasing and improving lands, town sites and territories and laying out, plotting, subdividing and colonizing the same.

\section{Article IV.}

The authorized amount of capital stock of this corporation shall be Two Million, Five Hundred Thousand $(\$ 2,500,000)$ Dollars, divided into Two Hundred and Fifty Thousand $(250,000)$ Shares of the par value of Ten (\$10) Dollars each. At such times as the Board of Directors may by resolution direct, said capital stock shall be paid into this corporation, either in cash or by the sale and transfer to it of real or personal property, contracts, services, or any other valuable right or thing for the uses and purposes of said corporation, in payment for which shares of the capital stock of said corporation may be issued and the capital stock so issued shall thereupon and thereby become 
and be fully paid-up and non-assessable, and in the absence of actual fraud in the transaction, the judgment of the directors as to the value of the property purchased shall be conclusive.

\section{Article V.}

The time of the commencement of this corporation shall be the date of the filing of a certified copy of these Articles of Incorporation in the office of the Auditor, and the termination thereof shall be twenty-five years thereafter, with the privilege of renewal as provided by law.

\section{Article VI.}

The affairs of this corporation shall be conducted by a Board of Directors, and the following named shall constitute the Board of Directors until their successors are elected: George $\mathrm{N}$. Wright, James Powers, Henry Decker, Harvey S. McLain, George Hessler. Thereafter the Board of Directors shall be elected from among the Stockholders at annual Stockholders' meeting to be held on the tenth day of January of each year.

\section{ArTicle VIII.}

The Directors shall have power to adopt and amend by-laws for the government of the corporation, to fill vacancies occurring in the Board from any cause, and to appoint an Executive Committee and vest said Committee with all of the powers granted the Directors by these Articles.

\section{ArTicLe VIII.}

The highest amount of indebtedness, direct or contingent, to which the corporation shall be subject at any one time shall be One Hundred Thousand $(\$ 100,000)$ Dollars.

\section{Article IX.}

The private property of the stockholders and officers of the corporation shall be exempt from all corporate debts of any kind whatsoever.

IN Witness WhEREOF, We have hereunto set our hands and seals this first day of September, 1909.

George N. Wright.

(Seal.)

JAMES POWERS.

(Seal.)

HeNRY Decker.

(Seal.) 
$\left.\begin{array}{l}\text { County of New York, } \\ \text { State of New YoRK, }\end{array}\right\}$ ss.:

Personally appeared before me this Ist day of September, 1909, George N. Wright, James Powers and Henry Decker, to me personally known to be the persons described in and who executed the foregoing certificate, and severally acknowledged that they executed the same for the purposes therein set forth.
$\left\{\begin{array}{c}\text { NOTARIAL } \\ \text { SEAL }\end{array}\right\}$
John S. Heller,
Notary Public for
New York County.

\section{Form Ir.-Comparative Table. Organization}

\section{Expenses.}

Including all Filing and Incidental Fees.

\begin{tabular}{r|r|r|r|r|r}
\hline $\begin{array}{r}\text { CAPITAL } \\
\text { STOCK OF } \\
\text { COM PANY }\end{array}$ & $\begin{array}{r}\text { NEW } \\
\text { JERSEY. }\end{array}$ & $\begin{array}{r}\text { NEW } \\
\text { YORK. }\end{array}$ & $\begin{array}{r}\text { DELA- } \\
\text { WARE. }\end{array}$ & MAINE. & $\begin{array}{r}\text { ARI- } \\
\text { ZONA.* }\end{array}$ \\
\hline & & & & & \\
\hline 1,000 & $\$ 35.00$ & $\$ 16.00$ & $\$ 25.00$ & $\$ 27.00$ & $\$ 50.00$ \\
5,000 & 35.00 & 17.50 & 25.00 & 27.00 & 50.00 \\
10,000 & 35.00 & 20.00 & 25.00 & 27.00 & 50.00 \\
25,000 & 35.00 & 27.50 & 25.00 & 67.00 & 50.00 \\
50,000 & 35.00 & 40.00 & 25.00 & 67.00 & 50.00 \\
100,000 & 35.00 & 65.00 & 25.00 & 67.00 & 50.00 \\
500,000 & 110.00 & 265.00 & 65.00 & 67.00 & 50.00 \\
$1,000,000$ & 210.00 & 515.00 & 115.00 & 117.00 & 50.00 \\
$5,000,000$ & $1,010.00$ & $2,515.00$ & 365.00 & 517.00 & 50.00 \\
$10,000,000$ & $2,010.00$ & $5,015.00$ & 615.00 & $1,017.00$ & 50.00 \\
\hline
\end{tabular}

It should be noted that the foregoing table includes filing and incidental fees as well as the state fees.

The list of states includes those most generally re-

*Including cost of publication; also fee (\$10) of statutory agent in Arizona for first year. 
sorted to for "outside" incorporation. West Virginia is omitted because of the onerous fees and requirements now imposed which remove the state from among those desirable for this purpose.

The New Jersey organization fee is 20c. for each $\$ 1,000$ of capitalization with $\$ 25$ as a minimum fee. The incidental fees approximate \$10. Non-resident corporations must maintain a state office with agent in charge thereof; cost $\$ 25$ to $\$ 50$ per annum.

The New York organization fee is I-20 of $1 \%$ of the capitalization; minimum \$I. Incidental fees approximate $\$$ I 5 . No state office need be maintained by corporations operating entirely outside the state.

The Delaware organization fee is Ioc. for each $\$ 1,000$ of capitalization up to a capitalization of $\$ 2,000,000$ with a minimum fee of $\$ 10.5 \mathrm{c}$. is charged on each $\$ 1,000$ in excess of $\$ 2,000,000$, with a minimum fee on this excess of $\$ 1$ Io. Incidental fees, approximately $\$ 15$. State office and resident agents cost from $\$ 25$ to $\$ 50$ per annum.

The Maine organization fees are as follows:-On capitalizations not exceeding \$10,000-\$10; over $\$$ Io,000 but not exceeding $\$ 500,000-\$ 50$; on larger capitalizations, $\$ 10$ for every $\$ 100,000$ of capitalization. Incidental fees approximately $\$ \mathrm{I} 7$.

In Arizona no organization tax is imposed but various fees aggregating about $\$ 35$, must be paid. These fees are the same for all incorporations regardless of the amount of capitalization. An office must be maintained in Arizona by non-resident corporations at a usual cost of \$Io per annum. 
Form 12.-Comparative Table. Annual Franchise Taxes.

\begin{tabular}{|c|c|c|c|c|c|}
\hline $\begin{array}{l}\text { CAPITAL } \\
\text { STOCK OF } \\
\text { COMPANY. }\end{array}$ & $\begin{array}{l}\text { NEW } \\
\text { JERSEY. }\end{array}$ & $\begin{array}{l}\text { NEW } \\
\text { YORK. }\end{array}$ & $\begin{array}{l}\text { DELA- } \\
\text { WARE. }\end{array}$ & MAINE. & ARIZONA. \\
\hline$\$ I, \infty 00$ & $\$ 1.00$ & $\$ \mathrm{I} .50$ & $\$ 5.00$ & $\$ 5.00$ & None \\
\hline 5,000 & 5.00 & $7 \cdot 50$ & 5.00 & 5.00 & \\
\hline Io,o00 & ro. 00 & 15.00 & 5.00 & 5.00 & "6 \\
\hline 25,000 & 25.00 & $37 \cdot 50$ & 5.00 & 5.00 & 6 \\
\hline 50,000 & 50.00 & 75.00 & I0.00 & 5.00 & "6 \\
\hline $100, \infty 00$ & 100.00 & I50.00 & 10.00 & 10.00 & "6 \\
\hline 500,000 & 500.00 & 750.00 & 25.00 & 50.00 & “6 \\
\hline $1,000,000$ & $1,000.00$ & $1,500.00$ & 50.00 & 75.00 & 6 \\
\hline $5,000,000$ & $4,000.00$ & $7,500.00$ & I50.00 & 275.00 & " \\
\hline $10,000,000$ & $4,250.00$ & r $5,000.00$ & 275.00 & 525.00 & "6 \\
\hline
\end{tabular}

It is to be noted that the franchise tax in the foregoing table has nothing to do with the tax imposed on personal or real property belonging to the corporation, which is the same in every respect as the tax imposed on personal or real property belonging to individuals. The franchise tax is merely a graduated charge for the privilege of doing business as a corporation.

The New Jersey franchise tax is I-IO of I\% on any capitalization up to $\$ 3,000,000 ; \mathrm{I}-20$ of $\mathrm{I} \%$ on any excess up to $\$ 5,000,000$; and for every $\$ 1,000,000$ over \$5,000,000, \$50. Manufacturing and mining corporations employing at least one-half their capital in the state are exempt.

The New York taxation given in the above table is calculated at the rate of one and one-half per cent., 
being based upon the supposition that all the capital is issued, that it is all employed in the state and that the corporation is paying six per cent. annual dividends. Any difference in any of these particulars affects the annual franchise tax. If a New York corporation is conducting all its business outside the state, merely maintaining an office in the state for its books and meetings, it pays no franchise tax. Mining, laundrying and manufacturing corporations employing not less than forty per cent. of their capital in the state are exempt from the franchise tax.

The Delaware franchise tax on capitalizations of $\$ 25,000$ or less is $\$ 5$; over $\$ 25,000$ to $\$ 100,000, \$ 10$; over $\$ 100,000$ to $\$ 300,000, \$ 20$; over $\$ 300,000$ to $\$ 500,000, \$ 25$; over $\$ 500,000$ to $\$ 1,000,000, \$ 50$; over $\$ 1,000,000$, a further sum of $\$ 25$ for each additional $\$ 1,000,000$ or part thereof. Manufacturing and mining corporations employing not less than onehalf their capital in the state are exempt from the franchise tax.

The Maine franchise tax on all capitalizations not exceeding $\$ 50,000$ is $\$ 5$ per annum; above $\$ 50,000$ but not exceeding $\$ 200,000, \$ 10$; above $\$ 200,000$ but not exceeding $\$ 500,000, \$ 50$; above $\$ 500,000$ but not exceeding $\$ 1,000,000, \$ 75$. $\$ 50$ additional must be paid for each $\$ 1,000,000$, or part thereof in excess of $\$ 1,000,000$. Manufacturing and mining corporations not exempt.

Arizona imposes no annual franchise tax. 


\section{CHAPTER XX.}

\section{BY-LAWS.}

As the general corporate mechanism is much the same in all corporations, there is a general resemblance between their by-laws. The details of these by-laws should, however, in each case be adapted to the special requirements of the corporation for which they are prepared. (See Ch. Iv, "By-laws.")

The set of by-laws which follows, though more particularly intended to illustrate the many references of the present volume to the by-laws, has been proved by long experience, and will afford very excellent material from which to construct the by-laws of any particular corporation. The set, though concise, is perhaps more complete than is entirely necessary for the smaller corporations-a fault that is not serious if the by-laws are properly adapted to the needs of the particular corporation.

Form 13.-By-Laws.

\section{By-Laws \\ of the \\ ALBANY MANUFACTURING CORPORATION.}

Article I.-Stockholders' MeEtings.

I. The Annual Meeting of the stockholders of the Company shall be held in the principal office of the Company in New 
York City at Io o'clock A. M. on the 3rd Monday of January of each year-if not a legal holiday; but if a legal holiday, then on the next business day succeeding-for the purpose of electing Directors and the transaction of such other business as may be brought before the meeting.

2. Special Meetings of the stockholders shall be held at the principal office of the Company and may be called by the President at his discretion and must be called by him when so directed by resolution of the Board of Directors, or when requested thereto in writing by stockholders holding one-third of the outstanding stock.

3. Notice of Meetings, written or printed, for every annual or special meeting of the stockholders shall be prepared and mailed to the post-office address of each stockholder as shown by the stock books of the Company not less than ten days before such meeting, and if for a special meeting such notice shall state the object or objects thereof, and no other business shall be transacted at any such special meetings save that so notified. No notice need be given of adjourned meetings.

4. A Quorum at any meeting of the stockholders, save as otherwise prescribed by statute, shall consist of a majority of the voting stock of the Company represented in person or by written proxy. A majority of such quorum shall be necessary to decide any question coming before the meeting. If a quorum is not present at any duly called meeting, a majority of those present may adjourn the meeting from day to day, but until a quorum is secured may transact no business.

5. Voting at Elections of Directors shall be by ballot, and shall also be by ballot on any other matter submitted to a stockholders' meeting when so requested by not less than one-fourth in interest of the stockholders present at such meeting. Each stockholder shall be entitled to one vote for each share of stock held by him and such vote may be cast in person or by written proxy.

6. The Election of Directors shall be held at the annual meeting of stockholders and shall be conducted by two inspectors of election appointed, after the first election, by the President.

7. The Presiding Officer at meetings of stockholders shall 
be the President, or in his absence or disability, the Vice-President. In the absence or disability of both of these officers, a Chairman shall be chosen by the stockholders present and shall preside at such meeting. In the absence of the Secretary of the Company, the presiding officer shall appoint a Secretary pro tem.

8. The Order of Business at the annual meeting and as far as possible at all other meetings of the stockholders, shall be:

I. Reading and Disposal of Any Unapproved Minutes.

2. Annual Reports of Officers and Committees.

3. Election of Directors.

4. Unfinished Business.

5. New Business.

6. Adjournment.

ARTICLE II.-DiRECTORS.

I. The Business and Property of the Company shall be managed by a Board of Seven (7) Directors, who shall be stockholders continuously during their respective terms of office and who shall be elected annually by ballot by the stockholders for the term of one year and shall serve until the election of their successors. Any vacancies in the Board may be filled by the remaining members of the Board for the unexpired term or terms. Directors shall receive no compensation for their services. Absence from four successive regular meetings of the Board of Directors may, in the discretion of the Board, terminate the membership of the absent director.

2. The Regular Meetings of the Board of Directors shall be held in the principal office of the Company in New York City at 3 P. M. on the third Tuesday of each month if not a legal holiday; but if a legal holiday, then on the next succeeding business day.

3. Special Meetings of the Board of Directors, to be held in the principal office of the Company in New York City, may be called at any time by the President or by any, three members of the Board, or may be held at any time and place without notice and for the transaction of any business by unanimous written consent of all the members or by the presence of all the members at such meeting. 
4. Notices of both regular and special meetings shall be mailed by the Secretary to each member of the Board not less than five days before any such meeting, and notices of special meetings shall state the purpose thereof, and no other business shall be transacted at a special meeting save as so notified unless by unanimous consent of all the members. No notice need be given of adjourned meetings.

5. A Quorum at any meeting shall consist of a majority of the entire membership of the Board. A majority of such quorum shall be necessary to decide any question that may come before the meeting. If a quorum is not present at any duly assembled meeting, a majority of those present may adjourn the meeting from day to day but may transact no other business until a quorum is secured.

6. Voting. Each member of the Board present in person at any meeting shall have one vote upon all matters voted upon at such meeting.

7. The Presiding Officer at meetings of the Directors shall be the President, or in his absence or disability, the Vice-President. In the absence or disability of both these officers, the directors present at any meeting shall appoint a Chairman who shall preside at such meeting. In the absence of the Secretary of the Company, the presiding officer shall appoint a Secretary pro tem.

8. Officers of the Company shall be elected by the Board of Directors at their first meeting after the election of Directors each year. If any office becomes vacant during the year, the Board of Directors shall fill the same for the unexpired term. The Board of Directors shall fix the compensation of the officers and agents of the Company. An officer may be removed at any time by a two-thirds vote of the entire membership of the Board.

9. The Order of Business at any regular meeting or special meeting of the Board of Directors shall be:

I. Reading and Disposal of Any Unapproved Minutes.

2. Reports of Officers and Committees.

3. Unfinished Business.

4. New Business.

5. Adjournment. 


\section{Article III.-OfFicers.}

I. The Officers of the Company shall be a President, who shall be elected from among the Directors, a Vice-President, a Secretary and a Treasurer, all of whom shall be elected for one year and shall hold office until their successors are elected and qualify. The positions of Secretary and Treasurer may be united in one person.

2. The President shall preside at meetings of stockholders and of Directors; shall have general supervision of the affairs of the Company; shall sign or countersign all certificates, contracts and other instruments of the Company as authorized by the Board of Directors; shall make reports to the Directors and stockholders, and perform all such other duties as are incident to his office or are properly required of him by the Board of Directors. In the absence or disability of the President, the Vice-President shall exercise all his functions.

3. The Secretary shall issue notices for all meetings of both stockholders and Directors; shall keep their minutes; shall have charge of the seal and corporate stock books; shall sign with the President all instruments requiring such signature, and shall make such reports and perform such other duties as are incident to his office or are properly required of him by the Board of Directors.

4. The Treasurer shall have the custody of all moneys and securities of the Company and shall keep regular books of account and balance the same each month. He shall sign or countersign such instruments as require his signature; shall perform all duties incident to his office or that are properly required of him by the Board, and shall give bond for the faithful performance of his duties in such sum and with such sureties as may be required by the Board of Directors.

\section{ARTICLE IV.-Stock.}

I. Certificates of Stock shall be in form approved by the Board of Directors; shall be numbered consecutively; be issued in numerical order from the stock certificate book; be signed by the President and Secretary, and be sealed with the corporate seal. A record of each certificate issued shall be kept on the stub thereof. 
2. Transfers of Stock shall be made only upon the books of the Company, and before a new certificate is issued, the old certificate properly endorsed shall be surrendered. Surrendered certificates shall be cancelled and be attached to their proper stubs in the stock certificate book. The stock books of the Company shall be closed to transfers twenty days before general elections and ten days before dividend days.

3. The Treasury Stock of the Company shall include such issued and outstanding stock of the Company as may be acquired by purchase, donation or otherwise and shall be held subject to disposal by the Board of Directors. Such stock shall neither vote nor participate in dividends while held by the Company.

\section{Article V.-Dividends and Finance.}

I. Dividends shall be declared only from surplus profits at such times as the Board of Directors shall direct, and no dividend shall be declared that will impair the capital of the Company.

2. The Moneys of the Company shall be deposited in the name of the Company in such bank or trust company as the Board of Directors shall designate, and shall be drawn out only by check signed by the Treasurer and countersigned by the President.

\section{Article VI.-Seal.}

I. The Corporate Seal of the Company shall consist of two concentric circles, between which appears the name of the Company, and in the centre shall be inscribed "Incorporated 1909, New York," and such seal, as impressed on the margin hereof, is hereby adopted as the Corporate Seal of the Company.

\section{Article VII.-Amendments.}

I. These By-Laws may be amended, repealed or altered, in whole or in part, by a majority vote of the entire outstanding stock of the Company, at any regular meeting of the stockholders, or at any special meeting where such action has been announced in the call and notice of such meeting.

2. The Board of Directors may adopt additional by-laws in harmony therewith, but shall not alter nor repeal any bylaws adopted by the stockholders of the Company. 
The foregoing by-laws comply with the requirements of the statutes of New York. When the set is to be used in another state, the corporation laws of that state should be consulted and the by-laws as given be modified to conform to their provisions. As a rule the necessary changes to meet the statute requirements of the different states are small, but it is imperative that they be made. (See Ch. Iv.)

The by-laws are usually prepared by the attorney having charge of the incorporation, in advance of the first meeting of stockholders. When presented to this meeting they should properly be read article by article and then adopted as a whole as the by-laws of the company. (See Form 22.) They are then usually ordered entered in the book of minutes immediately succeeding the copy of the certificate of incorporation. When so entered they should be certified by the secretary, or by the president and secretary, as in the following form:

\section{Form I4.-Certification of By-Laws.}

We, the undersigned, President and Secretary of the Albany Manufacturing Company, do hereby certify that the foregoing are the By-Laws of the said corporation duly adopted by the stockholders thereof, at their first meeting held in the City of New York, on the roth day of October, 1909, all as shown by the Minutes of said meeting.

In WrTness WheReof, we have hereunto affixed our official signatures and the corporate seal of said corporation on this 15 th day of October, 1909.

$\left\{\begin{array}{c}\text { CORPORATE } \\ \text { SEAL }\end{array}\right\}$

James T. Howell, President. Thomas Trent, Secretary. 


\section{Form 15.-Certified Extract from By-Laws.}

\section{SPRINGVIEW WATER COMPANY.}

TransCRIPT FROM By-Laws.

\section{"ArTICLE III.-OFFICERS.}

\section{"Sec. 2. The President.}

"The President when present shall preside at all meetings of the Stockholders and of the Board of Directors; shall sign all certificates of stock; shall sign or countersign as may be necessary all such bills, notes, checks, drafts and other instruments as may pertain to the ordinary course of the Company's business, and shall sign when duly authorized thereto all contracts, orders, deeds, licenses and other instruments of a special nature.

"He may also in the absence or disability of the Treasurer, endorse checks, drafts and other negotiable instruments for deposit or collection, and shall with the Secretary sign the minutes of all meetings over which he presides."

I, John H. Bowen, Secretary of the Springview Water Company, do hereby certify that the above is a true and correct copy of Section 2, Article III, of the duly adopted By-Laws of this Company, and in testimony thereof I have hereunto affixed my official signature and the seal of the Company in the City of Saratoga, State of New York, on this 21st day of September, 1909. 


\section{CHAPTER XXI.}

FIRST MEETINGS.

Form 16.-Proxy. First Meeting of Stockholders.

\section{Proxy \\ for}

First Stockholders' Meeting.

Know All Men By These Presents, That I, the undersigned, one of the incorporators and a subscriber to the stock of the Jersey City Paving Company, do hereby constitute and appoint John N. Michael of Jersey City, New Jersey, my true and lawful attorney, with full powers of substitution and revocation, to represent me at the first meeting of the stockholders of said corporation to be held on the 2oth day of August, 1909, and at any meeting postponed or adjourned therefrom, hereby granting my said attorney full power and authority to act for me at said meeting, and, in my name, place and stead, to vote thereat upon the stock of said corporation subscribed for by me, or upon which I may then be entitled to vote, in the election of Directors and in the transaction of any and all other business pertaining to the affairs of the Company that may be brought before said meeting, all as fully as I might or could do if personally present, and I hereby ratify and confirm all 
that my said attorney, or his substitute, shall lawfully do at such meeting in my name, place and stead.

IN WitTNesS WhEREOF, I have hereunto affixed my signature and seal, this I3th day of August, I909.

Frank M. Willis. , [L. S.]

In presence of:

JAMES Carhart.

This proxy is formal and complete. It is valid for the first meeting and any meetings adjourned therefrom, but then expires without revocation. (See Ch. Xxiv.)

Form 17.-Call and Waiver. First Meeting of Stockholders.

Call and Waiver of Notice

for

FIRST MEETING OF STOCKHOLDERS.

We, the undersigned, being all of the incorporators and stockholders of the Chilworth Manufacturing Company, do hereby call the first meeting of the stockholders thereof, to be held in the office of James P. Gregory, 35 Liberty Street, New York City, August Ioth, I909, at Io o'clock A. M., for the organization of the Company and the transaction of all such business as may be incident thereto, and we hereby waive all requirements as to notice of such meeting and consent to the transaction thereat of any and all business pertaining to the affairs of the Company.
James H. Marshall.
Percy Sheldon.
Harry Adams.
JAMES CHILWORTH..
JAMES P. GREGORY.

New York, August Io, 1909. 


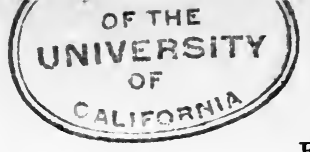

FIRST MEETINGS.

It is to be borne in mind that immediately after the granting of its charter, the corporation has neither by-laws, directors nor officers; hence the importance of the first, or organization, meetings. These initial meetings of stockholders and directors are most conveniently assembled by means of calls and waivers of notice. These, if signed by all parties concerned, are all-sufficient and save the time and trouble involved in personal notification or notice by publication. If, however, any person or persons entitled to be present at such a meeting, should not sign, such omission might invalidate the proceedings of the whole meeting. (See $\S \S 53,54$, I 20.$)$

The foregoing call and waiver is somewhat informal, but is short, simple and entirely sufficient for the smaller companies, or for the larger companies when no specially important action is contemplated.

It is to be noted that in New York the first meeting of stockholders loses something of its importance because the directors for the first years are named in the charter. In most of the states they are elected by the stockholders and this election is the most important business coming before the meeting and should be specifically mentioned in the call and waiver. In such case the purposes of the meeting would read as follows :-

"for the purpose of receiving charter, electing directors, adopting by-laws and the transaction of such other business as may be incident or necessary to the organization of the company." 
Form 18.-Call and Waiver. First Meeting of Directors.

Call and Waiver of Notice

for

FIRST MEETING OF DIRECTORS.

We, the undersigned, being all the Directors of the Chilworth Manufacturing Company, do hereby call the first meeting of the Directors of said Company, to be held in the office of James P. Gregory, 35 Liberty Street, New York City, at II o'clock A. M., on the roth day of August, 1909, for the purpose of electing officers of the Company, acting upon a proposition to exchange property for the stock of the Company and doing all such other things as may be necessary or desirable in connection with the organization of the Company or for the promotion of its business, and we hereby waive all statutory and by-law requirements as to notice of time, place and objects of said meeting and consent to the transaction thereat of any and all business pertaining to the affairs of the Company.

James Chilworth.

JAMES P. GREgory.

New York City, August 1o, 1909. Percy Sheldon.

The two meetings are usually called for the same day, that of the stockholders coming first and that of the directors an hour or so later. (See $\S \S 67$, I27.)

Form 19.-Issuance of Stock for Property. Proposal.

192 Montague St., Brooklyn, N. Y., August 8, 1909 .

To the Stockholders and Directors of

The Chilworth Manufacturing Company,

35 Liberty St., New York City:

GentLemen-In exchange and full payment for the entire cap- 
ital stock of the Chilworth Manufacturing Company, including with the consent of the incorporators, the shares subscribed for by them, I hereby offer you the plant for the manufacture of cooper's supplies and machinery, belonging to me and located on the water front near the foot of East 128th Street, New York and bounded and described as follows:-(Description.) Included with said plant are all the machinery, tools, apparatus and materials, raw or manufactured, now in said buildings or on the premises, the whole being sold as a going concern, and all of said plant and property being free and unincumbered and of the reasonable value of $\$ 60,000$.

If the above proposition is accepted, the entire capital stock of your Company, excepting the shares subscribed for by the incorporators, which are to be issued to them, is to be issued to my order, full-paid and non-assessable, against the delivery to your representatives of such duly executed deeds and assignments of the above plant and property as may be satisfactory to your attorneys.

In the event of your acceptance of the foregoing proposition, I shall donate and turn over to your Company not less than $\$ 25,000$ face value of the stock received by me, such stock to be used at the discretion and under the direction of your Board of Directors, for the purpose of providing working capital for the Company.

Yours very truly,

Henry M. Grenelle.

This proposal is merely a convenient method of getting the matter of issuing stock for property before the meetings of stockholders and directors. Such a proposal, when followed by, resolutions of the stockholders approving it, and resolutions of the directors accepting it, constitutes a complete contract. The minutes of the respective meetings of the stockholders and directors should give complete and accurate records of the proceedings in connection with the ex- 
change of stock for property. The forms of resolutions which follow might be appropriately adopted by the stockholders and directors respectively if the proposal is to be accepted. (See $\S \S$ I24, I25, I30.)

\section{Form 20.-Issuance of Stock for Property. Stock- holders' Resolution.}

Whereas, A proposition has been received from Mr. Henry M. Grenelle, offering to sell, assign and convey to this Company the property near the foot of East I28th St., New York, known as the Grenelle Manufacturing Plant, in exchange for the entire capital stock of the Company to be issued full-paid and nonassessable to the order of the said Henry M. Grenelle, save as to the shares subscribed for by the incorporators; and

Whereas, It appears to the stockholders of this company that the said property is desirable for the purposes of the Company and is reasonably worth the purchase price thereof:

Now, Therefore, BE IT Resolved, That the said proposition for the exchange of said property for the entire capital stock of this Company, as set forth in this proposition, be and hereby is approved, and the Board of Directors of this Company are hereby authorized, empowered and instructed to accept the said proposition and to cause the entire capital stock of the Company to be issued for the said property, in accordance with the terms of said proposition.

Form 21.-Issuance of Stock for Property. Directors' Resolution.

WhEREAS, The property offered in exchange for the Capital Stock of this Company by Mr. Henry M. Grenelle in his proposition to the Company is adjudged by this Board to be of the reasonable value of Sixty Thousand $(\$ 60,000)$ Dollars, and to be necessary for the use and lawful purposes of the Company. 
RESOLVED, That the said property be and hereby is, in accordance with the authorization and instructions of the stockholders of this Company, accepted in full payment for the said capital stock of the Company, in accordance with the terms of said proposition; and the proper officers of this Company are hereby authorized and directed to receive the duly executed transfers and assignments of the property specified in said proposition and to issue in exchange therefor the entire stock of the Company, full-paid and non-assessable, to such person or persons as may be designated by the written orders of the aforementioned Henry M. Grenelle, except as to the shares subscribed for by the incorporators, which shall be issued to them or their order.

It is to be noted that the decisive action is taken by the directors in the foregoing resolution, and that the 'stockholders' resolution merely approves the transaction and authorizes the directors to take action. (See § 130 .)

The wording of the directors' resolution adjudging the property to be of the proper value and to be necessary for the use and lawful purposes of the company is the usual form. Also it is in accord with the New Jersey statutes on this subject which read as follows:-

"In the absence of actual fraud in the transaction the judgment of the directors as to the value of the property purchased shall be conclusive." (Gen. Corp. Law of N. J., § 49.)

New York and some other states have followed the New Jersey laws in regard to this matter, and in any state where it is allowable to issue stock for property, a fair transaction of the kind would be upheld. 


\section{CHAPTER XXII.}

MINUTES OF FIRST MEETINGS.

The following minutes of the first meeting of stockholders follow the New York practice. With the addition of an election of directors, they would be suitable for most of the other states. In New Jersey, Delaware and some other states it would be necessary to pass a resolution designating the state office and resident agent. (See Ch. XIII.)

Form 22.-Minutes. First Meeting of Stockholders.

\section{CHILWORTH MANUFACTURING COMPANY.}

Minutes of First Meeting of Stockholders.

Held August Io, I909.

Pursuant to written call and waiver of notice, the first meeting of stockholders of the Chilworth Manufacturing Company was held in the office of James P. Gregory, 35 Liberty Street, New York City, at Io o'clock A. M., on the Ioth day of August, I909, with all the stockholders present, either in person or by proxy.

Mr. James Chilworth was chosen Chairman and called the. meeting to order. Mr. Percy Sheldon was appointed Secretary of the meeting. 
The following stockholders were present in person:

SHARES

NAME.

SUBSCRIBED.

James Chilworth ......................... $\quad 25$

Percy Sheldon $\ldots \ldots \ldots \ldots \ldots \ldots \ldots \ldots \ldots \ldots \ldots \ldots$ r.

James P. Gregory ........................ Io

The following stockholders were present by proxies duly presented and filed with the Secretary:

SHARES

NAME. NAME OF PROXY.

SUBSCRIBED.

James H. Marshall......Warren Coles........... Io

Harry Adams...........Harvey Clinton.......... 5

The Secretary presented the call and waiver of notice pursuant to which the meeting was held, duly signed by all the incorporators of the Company. Said call and waiver was ordered spread upon the Minute Book immediately following the minutes of the meeting. (See Form I7.)

The Chairman then presented a certified copy of the Certificate of Incorporation of the Company and stated that said certificate had been filed with, and recorded by, the Secretary of State on the 7th day of August, I909, and that a duplicate copy had been filed for record with the County Clerk on the gth day of August, 1909.

Upon motion, duly made and carried, said Certificate of Incorporation was ordered received, the Directors named therein were recognized as the Directors of the Company, and the Secretary was instructed to spread the said Certificate in full upon the first pages of the Book of Minutes.

The Chairman also presented a form of By-laws, prepared by James P. Gregory, Esq., Counsel for the Company, which was read, article by article, and, as a whole, unanimously adopted as the By-laws of the Company, and ordered entered in the Minute Book immediately following the Certificate of Incorporation.

The Secretary then presented a written proposal from $\mathrm{Mr}$. Henry M. Grenelle, of 192 Montague Street, Brooklyn, offering to transfer and assign to the Company certain property, as set forth in said proposal, in exchange for the entire capital stock of the Company. (See Form Ig.) 
After due consideration said proposal was ordered received and the following resolution in regard thereto was moved, seconded and passed by unanimous vote:

(Insert here Resolution of Stockholders, Form 20.)

There being no further business before the meeting, it was adjourned.

James Chilworth,

Chairman.

Percy Sheldon,

Secretary.

Mr. Grenelle's proposition might have been entered in full in the minutes of this first meeting of stockholders, and, if so, would appear after the minutes, or, if the secretary prefers, in the body of the minutes just after the paragraph descriptive of the proposition and its presentation by the secretary. In such case it would be prefaced by the following statement :

"Said proposition was ordered received and spread upon the minutes and is as follows:"

Inasmuch, however, as the proposition should properly appear in the minutes of the directors' meeting where it is formally acted upon, it is better omitted from the stockholders' minutes unless there is some special reason for its inclusion.

In any other state than New York, an election of directors would be an important feature of the minutes of the first stockholders' meeting. This election would be held immediately after the adoption of the by-laws and would be duly recorded in the minutes just after the entry relating to the by-laws. The recognition of the directors set forth in the paragraph accepting the charter would, of course, in such event be omitted. 


\title{
Form 23.-Minutes. First Meeting of Directors.
}

\section{CHILWORTH MANUFACTURING COMPANY.}

\author{
Minutes of the First Meeting of Directors. \\ Held August 10, 1909.
}

Pursuant to written call and waiver of notice, the Board of Directors of the Chilworth Manufacturing Company held its first meeting in the office of James P. Gregory, 35 Liberty Street, New York City, at II o'clock A. M., on the Ioth day of August, 1909.

Mr. James Chilworth was chosen as temporary Chairman and Mr. Percy Sheldon was appointed temporary Secretary of the meeting.

All the members of the Board were present as follows:

James Chilworth.

James P. Gregory.

Percy Sheldon.

On request of the Chairman the Secretary presented the Call and Waiver of Notice, pursuant to which the meeting was held, duly signed by all the members of the Board. It was ordered spread upon the Minute Book immediately following the minutes of the meeting. (See Form 15.)

The Chairman then appointed Messrs. James P. Gregory and Percy Sheldon, tellers to conduct the election for officers of the Company, the officers so elected to serve for the remainder of the corporate year and until the election of their successors.

The votes of those present were then duly cast by ballot, resulting in the election by unanimous vote of the following officers :

President ..................James Chilworth.

Vice-President ............... James P. Gregory.

Secretary and Treasurer .........Percy Sheldon.

The permanent officers of the Company thereupon took charge of the meeting. 
The Secretary presented a form of stock certificate for approval, which was by motion adopted as the form for the stock certificates of the Company as prepared by its Directors, and the Secretary was instructed to spread the said form upon the pages of the Minute Book immediately following the record of the meeting then in progress.

The President then presented a written proposal from $\mathrm{Mr}$. Henry M. Grenelle, of Brooklyn, offering to assign to the Company, in exchange for its entire Capital Stock, certain specified property. The said proposal was ordered spread in full upon the minutes and is as follows:

(Insert here Proposal to Exchange Property for Stock, Form I9.)

The President also presented a resolution of the stockholders, approving the said proposal and authorizing and instructing the Directors to accept the same and to take such action in regard thereto as might be necessary to make such acceptance fully effective.

The following resolution was thereupon moved, seconded and unanimously adopted:

(Insert here Resolution of Directors, Form 2I.)

Upon motion duly made, seconded and passed, the following resolution was adopted:

(Insert here Resolution from Form 52.)

The following motions were then made, seconded and duly passed by the unanimous vote of all present:

Moved, That the President be hereby authorized to lease for the use of the Company such suitable office or offices in this City as may be necessary for the proper transaction of the Company's business, such lease to be for one year, with privilege of renewal, at an annual rental not exceeding $\$ 900$, and the office so secured to be the principal office of the Company within the State of New York.

Moved, That the Secretary be hereby instructed to procure a corporate seal and a book of five hundred stock certificates; also all such record, stock and transfer books, and books of account and stationery and office supplies, as may be necessary for the proper operation and record of the Company's business and transactions. 
Moved, That the Secretary be instructed to prepare or have prepared, in due and proper form, a certificate of the payment of one-half the capital stock of the Company, and, after the due execution and verification thereof, to file said certificate as required by law, and to spread a copy thereof upon the pages of the minute book following the record of the present proceedings.

Moved, That the Treasurer be hereby authorized and instructed to pay from the Company funds the expenses properly incurred in the incorporation of the Company or in connection therewith.

Moved, That Messrs. William H. Coles and Richard Jennings be hereby appointed inspectors of election to serve at the first annual election of Directors of the Company, and at any election of directors by the stockholders previous thereto.

There being no further business for consideration the meeting was adjourned.

JAmes Chilworth, President.

Percy Sheldon, Secretary.

In the minute-book, following the preceding minutes, should appear the call and waiver of notice and the form of stock certificate adopted at the meeting; also copy of the certificate of payment of one-half the capital stock of the company. The proposal for the exchange of property for the stock of the company might be entered in the same way after the record of the proceedings, but is used so directly as a basis for the subsequent proceedings that it is perhaps better incorporated in the minutes as shown.

If bond is required of the treasurer, and the by-laws do not specify the amount, surety or sureties, and other details, action thereon should be taken at this 
first meeting and should appear just after the record of the election of officers as follows:

"By motion, duly seconded and passed, the amount of the Treasurer's bond was fixed at $\$ 1,000$, such bond to be in form and with sureties approved by the Board.

"The Treasurer-elect then presented a bond of the Guaranty Bonding Company of New York City for said amount. The form of the instrument and the surety thereon meeting with the approval of the Board, the bond as presented was formally accepted and placed in custody of the President."

(See generally Ch. xiv, "First Meeting of Directors." For treasurer's bond see Form 74.) 


\section{CHAPTER XXIII.}

\section{CALLS AND NOTICES.}

\section{Form 24.-Notice of Annual Meeting.}

\section{ALBANY MILLING COMPANY,}

I42 Capitol Street, Albany, New York.

Mr. John J. Wellman,

JULY 30, 1909.

\section{I63 Capitol Street, Albany, N. Y.:}

DeAr Sir,-You are hereby notified that the Annual Meeting of the Stockholders of the Albany Milling Company will be held in the Company's office at Io o'clock A. M., Tuesday, August 2I, 1909, for the purpose of electing Directors and for the transaction of such other business as may come before the meeting.

Respectfully,

Sherman H. Montgomery,

Secretary.

In those states where the statutes require publication of the notice of the annual meeting, the following form will be found suitable. Notice by mail should be sent in addition to the publication notice when this latter is used, as announcements in the papers are rarely effective. (See $§ 54$.) 
Form 25.-Notice of Annual Meeting. Publication.

ALBANY MILLING COMPANY.

The Annual Meeting of the Stockholders of the Albany Milling Company will be held at the office of the Company, I42 Capitol Street, Albany, New York, August 21st, 1909, at Io o'clock A. M., for the purpose of electing Directors and for the transaction of such other business as may be brought before said meeting.

The stock transfer books of the Company will be closed at 3 o'clock P. M. August 2nd, 1909, and remain closed until ro o'clock A. M. August 23rd, I909.

Sherman H. Montgomery,

Secretary.

When a special meeting of either stockholders or directors is to be held, time is saved and all risk of faulty notice avoided if the meeting is assembled by means of a call and a waiver of notice signed by all the interested parties. Such call and waiver for a stockholders' meeting assembled to discuss and act upon a proposition to sell the entire assets of the company is as follows: (See $\S \S 53,54$.)

Form 26.-Call and Waiver. Special Meeting of Stockholders.

THE SHELBY BRASS COMPANY.

Call and Watver for Special Meeting of Stockholders.

We, the undersigned, being all the stockholders of The Shelby Brass Company, hereby call a special meeting of the stockholders of said Company to be held in the Company's office, No. I45 Main Street, Harrisburg, Pa., at ro o'clock A. M., on the Ist 
day of October, 1909, for the purpose of considering and acting upon a proposition for the sale of the entire assets of the Company, and we hereby waive all statutory and by-law requirements as to notice of time, place and objects of said meeting, and agree to the transaction thereat of any and all business pertaining to the affairs of the Company.

Harrisburg, Pa.,

September 29, 1909.
Alfred Languedoc.

George Wells Brown.

James P. Harmon.

Henry M. Allen.

If for any reason the call and waiver is not available or desirable, special meetings may be assembled by means of a suitable call duly followed by the secretary's notice. (See $\S 54$.) The by-laws usually prescribe the requirements of the call. The following form is applicable when special meetings may be called by two or more directors of the company.

Form 27.-Call for Special Meeting. Stockholders'.

Call for Special Meeting of Stockholders.

Whe, the undersigned, Directors of the Shelby Brass Company, do hereby call a special meeting of its stockholders to be held in the office of the Company, 145 Main Street, Harrisburg, $\mathrm{Pa}$., on the Ist day of October, I909, at Io o'clock A. M., for the purpose of considering and acting upon a proposition to sell the entire assets of the Company and for the transaction of all such business as may be necessary or desirable in connection therewith; and we hereby authorize and instruct the Secretary of the Company to send out notices of said special meeting in accordance with the by-law requirements of this Company.

Harrisburg, Pa., September 25, 1909.

To Mr. William J. Willford,

Henry M. Allen. Alfred Languedoc.

Secretary of the Shelby Brass Company. 
This call is handed, or mailed, to the secretary, who then, in accordance with its specifications, sends out notice of the meeting.

The following form of notice is generally applicable. The authority under which it is issued should be specified in the notice.

Form 28.-Notice of Special Meeting. Stockholders'.

THE SHELBY BRASS COMPANY.

Harrisburg, Pa., September 25, 1909.

Mr. JAMES P. HARMon,

Lykens, $\mathrm{Pa}$.

DeAr SiR,-You are hereby notified that, pursuant to call duly signed by two Directors of the Company, a special meeting of the stockholders of the Shelby Brass Company will be held in the Company's office, No. I45 Main Street, Harrisburg, Pa., October I, I909, at Io o'clock A. M., for the purpose of considering and acting upon a proposition to sell the entire assets of the Company, and for the transaction of any and all business necessary or desirable in connection therewith.

Yours very truly,

WIILLIAM J. WiLford, Secretary.

This notice may be used as shown, or with the name and address of the particular stockholder omitted. This latter practice is common where the notices are printed, the address appearing only on the envelope in which the notice is enclosed. Frequently the notice is printed on a postal card, in which case the address appears only on the address side of the card. 
For regular meetings of directors notice is sent to every member of the Board, as may be prescribed by the by-laws, usually from five to ten days before the date of meeting.

Form 29.-Notice of Regular Meeting. Directors'.

\section{WELLMAN ENGINE COMPANY.} 305 Broadway.

Mr. James H. Hallock, New York, July 27, 1909.

DEAR SIR : 654 Fifth Ave., City.

You are hereby notified that the regular monthly meeting of the Board of Directors of the Wellman Engine Company will be held in the offices of the Company at 305 Broadway, August 7th, I909, at Io o'clock A. M.

Respectfully,

Henry Wellman, Secretary.

Special meetings of the board of directors may be assembled by call and waiver where it is desirable to save time. The form in such case may be as follows: (See $\S \S 67,68$. )

Form 30.-Call and Waiver. Special Meeting of Directors.

THE FREMONT STEAMSHIP COMPANY.

Call and Waiver for Special Meeting of Directors.

We, the undersigned, being all the Directors of The Fremont Steamship Company of New York City, hereby call a special 
meeting of the Board of Directors of said Company to be held in the Company's office, I33 South Street, New York City, on July I5, 1909, at 3 o'clock P. M., to elect a Treasurer of the Company and to transact any other necessary business in connection therewith, and we hereby waive all statutory and by-law requirements as to notice of time, place and purpose of said meeting and consent to the transaction thereat of any and all business pertaining to the affairs of the Company.

New York City, July I3, I909.

Wilhelm VoN LOSSBERGH.

Wilson T. CORWIN.

Henry Brewster Symmes.

MORRIS T. CORNELL.

James B. Hartleigh.

When the call and waiver can not be used, the meeting must be assembled by a call followed by notice. The following form may be used when the bylaws authorize the president to summon such meetings.

Form 30a.-Call for Special Meeting. Directors'.

THE FREMONT STEAMSHIP COMPANY.

I33 South St., New York.

To the Secretary of the

July $12, \quad 1909$.

Fremont Steamship Company.

I hereby call a special meeting of the Board of directors to be held in the office of the Company at 3 o'clock P. M., on the I5th day of July, I909, for the purpose of acting upon the resignation of the Treasurer of the Company, Mr. John Ellis, for the election of his successor, in the event of the acceptance of said resignation, and for the transaction of any other business 
in connection therewith that may be necessary; and you are hereby instructed to send out notices of said meeting as required by the by-laws of this Company.

WILHELM VON LOSSBERGH,

President.

This call should be handed or mailed to the secretary, and it then becomes the duty of that official to see that the required notices of the meeting are duly sent out. The form of this notice may be as follows :

Form 3r.-Notice of Special Meeting. Directors'.

THE FREMONT STEAMSHIP COMPANY.

I33 South St., New York.

Mr. James B. Hartleigh,

July 13,1909 . 178 West End Ave., City.

DeAr Sir:-You are hereby notified that, pursuant to call of the President, a special meeting of the Board of Directors of this Company will be held in its office at 3 o'clock P. M., on the 15 th day of July, 1909, for the purpose of acting upon the resignation of the Treasurer of the Company, Mr. John Ellis, for the election of his successor, if said resignation is accepted, and for the transaction of such other business in connection therewith as may be necessary.

Respectfully,

W'illis Carey, Secretary. 


\section{CHAPTER XXIV.}

\section{PROXIES.}

The proxy is merely a special power of attorney, given by a stockholder and authorizing the party to whom it is given to represent and act for such stockholder at one or more stockholders' meetings of the particular company.

Proxies must be in writing and either the original or a certified copy should be filed with the secretary of the company at or before the time of any meeting where such proxy is to be used.

Revocations of proxies should also be in writing and be filed with the secretary of the company. A second proxy covering the same stock as does an outstanding proxy acts as a revocation of the first even though it does not specifically so state.

Proxies should be signed and sealed by the maker and be witnessed by at least one person. Ordinarily they do not require acknowledgment. A proxy may be-and frequently is-given with the name of the acting party omitted. Such blank proxy is usually handed or sent to the secretary of the company or to 
some associate or friend who will be in attendance, and, at the time of the meeting, is filled in with the name of some suitable person present who is thereby empowered to act.

A party authorized to act by a proxy ean not delegate this authority unless he is expressly and formally empowered so to do by the giver of the proxy. If the stock represented by a proxy is sold the proxy is thereby made void and of no effect. (See generally $\S 57$.

Form 32.-Simple Proxy. Unlimited.

Proxy.

Know All Men By These Presents, That I, the undersigned, do hereby constitute and appoint John Calhoun my true and lawful attorney to represent me at all meetings of the stockholders of the Corliss Malting Company, and for me and in my name and stead to vote thereat upon the stock standing in my name on the books of said Company at the times of said meetings, and I hereby grant my said attorney all the powers that I should possess if personally present.

Witness my signature and seal this Ioth day of August, I909.

In presence of

$$
\text { William H. Coles. [L. S.] }
$$

Frederick Spencer.

This proxy is short and simple as to form, but is somewhat broad in its scope. It is unlimited as to time, and, until revoked or terminated by some statutory limitation, applies to every stockholders' meeting, 
regular, special or adjourned. It authorizes the appointee to participate in any way that any stockholder might at such meetings, and, generally, places the appointee in the position of the owner himself in reference to any corporate action.

The proxy given might be limited as to time, say to a six months' term, by adding the phrase "held on or before the roth day of January, I9Io," immediately after the name of the company in the body of the proxy, or it might be limited to a single meeting by proper specification, as "to represent me at the special meeting of the stockholders of the Corliss Malting Company to be held on the I 5 th day of August, 1909."

\section{Form 33.-Formal Proxy. Annual Meeting.}

Proxy.

Know All Men By These Presents, That we, the undersigned, stockholders of the Corliss Malting Company, do hereby constitute and appoint Henry Bronson our true and lawful attorney, with full power of substitution and revocation, for us and in our names, place and stead, to vote upon the stock then standing in our respective names upon the books of said Company, at the annual meeting of the stockholders thereof, to be held in the office of the Company, Ioo Broadway, New York City, August Ioth, I909, at Io o'clock A. M., and at any meeting postponed or adjourned therefrom, hereby granting to our said attorney full power and authority to act for us at said meeting, and, in our names and stead, to vote thereat upon our said stock in the election of Directors and in the transaction of such other business as may be brought before the said meeting, all as fully as we might or could do if personally present, and we hereby ratify 
and confirm all that our said attorney, or his substitute, shall lawfully do at such meeting in our names, place and stead.

IN WITNESS WHEREOF, we have hereunto affixed our signatures and seals this 5th day of August, 1909.

Howard Bachman. [L. S.]

Samuel Adams. [L. S.]

In presence of:

JASPER LONSDALE. [L. S.]

William H. JoRdon

as to Howard Bachman.

Francis B. Smythe

as to Samuel Adams

and Jasper Lonsdale.

This proxy is specific and formal. It does not convey any greater or more complete powers than the shorter form already given. It is, however, conventional and will be found more satisfactory under formal conditions or where matters of much importance are to be considered.

Form 34--Revocation of Proxy.

Revocation of Proxy.

I, the undersigned, do hereby revoke and annul any and all proxies or powers of attorney heretofore given by me, as far as the same may authorize or empower any person or persons to represent me, vote in my name and' stead, or act for me in any way whatsoever, at any meeting or meetings of the stockholders of the Corliss Malting Company.

Witness my signature and seal this 5 th day of October, I909.

In presence of:

$$
\text { Nathan Goodhue. [L. s.] }
$$

Harvey McKay. 
The above revocation is sweeping and when delivered to the secretary of the company annuls all outstanding proxies for the stock mentioned. If any proxy is to be excepted from the general revocation, that fact should be specifically mentioned, or the revocation might be limited to the particular proxies to be annulled, leaving any other outstanding proxies unaffected. (See generally $\S 57$; also Form I6.) 


\section{CHAPTER XXV.}

\section{MINUTES.}

The minutes of a meeting should be a concise, accurate record of the important proceedings of that meeting. No attempt should be made to record everything that occurs. Unimportant matters are properly omitted and those of more importance entered as briefly as is consistent with clearness and accuracy.

The detail and formality of the secretary's record will depend largely upon the nature of the proceedings. Where action is unimportant, or, if important, is unanimous, but little formality or particularity of detail is required in the minutes. If, however, matters are important and there is a difference of opinion, every essential detail should be entered in full. Motions and resolutions should be given verbatim, and, in the record of directors' meetings, the names of those voting and how their votes were cast should be stated in full. In matters of unusual importance the essential features of discussion, and motions made but lost will sometimes be recorded.

It may be said generally, however, that minutes, outside of the routine statements as to time, place, attendance, etc., are intended to be a record of what is done-not of discussion or proposed action-and only such matters should be entered as are necessary to con- 
stitute an accurate record of the actual transactions of the meeting.

Minutes are signed by the secretary and president and if properly kept are competent evidence of the proceedings of the meetings recorded.

\section{Form 35.-Annual Meeting of Stockholders.}

\section{ELLENVILLE WOOLEN MILLS COMPANY.}

Minutes of Annual Meeting.

Held August 25, 1909.

The stockholders of the Ellenville Woolen Mills Company assembled in annual meeting in the office of the Company at II o'clock A. M., August 25, 1909.

The meeting was called to order by Mr. Herbert Wilson, President of the Company. Mr. Henry H. Elgin acted as Secretary.

There were present 4,500 shares out of 5,000 shares of stock outstanding, constituting a legal quorum.

The Secretary submitted a copy of the notice of meeting with his certificate attached, showing that copies thereof had been mailed to each stockholder of record on or before the 14th day of August, I909. Copies of the "Ellenville Record" under date of August I4th and 2Ist, containing due notice of said meeting, were also submitted.

No objection being offered, the proof of notice of meeting as submitted was ordered received and filed. (For notice of meeting see Forms 24 and 25.)

The minutes of the preceding annual meeting were then read and approved.

The President stated that the next business in order was the annual reports of officers and committees, but added that his own report, as President, was not then ready to present, as matters of much importance had come up within a few days of the date of the meeting and were then pending, which he wished to present in connection with his report, and that the 
stockholders would therefore be called together in special meeting at a later date for the purpose of receiving and considering the President's report. .

The Treasurer's annual report was then presented, and, by request, was read by him. No objection being offered the report was ordered received and filed.

The Committee of Stockholders appointed at the preceding annual meeting to examine and report upon the plan and equipment of the Company submitted an extended report, which was ordered received and filed.

The President then announced the election of five directors to serve for the ensuing year as next in order, and appointed Edward E. Simes and James Warrington inspectors of election.

The following names were placed in nomination: Henry F. Disbrow, Percy Warren, Ellison Hyde, George S. Stephenville, Harry O. French, William S. Symington, Allen S. O'Dell, Henry S. Ellsworth and Herbert Wilson.

The inspectors of election having been first duly sworn, took charge of the election. Voting was by ballot and resulted in the election of the following Directors:

Percy Warren.

Harry O. French.

William S. Symington.

Henry S. Ellsworth.

Herbert Wilson.

The report of the Stockholders' Committee on the plant and equipment of the Company was then taken up for consideration.

By request, Mr. David McMahon, Chairman of the Committee, gave a synopsis of the report, stating as the conclusion of the Committee that while both buildings and equipment were in good condition, the equipment was very much out of date and should be replaced, and that the changes in the buildings necessary for the installment of new and modern machinery should be begun without delay. Mr. McMahon stated that the cost of such new installation would be about $\$ 50,000$ but that he fully believed this entire amount would be returned to the Company in the shape of increased profits in the first year of operation with the new equipment.

After a full discussion of the matter the following resolution was adopted: 
Resolved, That the stockholders of this Company do hereby approve of the recommendations made in the report of Mr. McMahon's Committee and that a copy of said report be submitted to the Directors of the Company, and that the Directors be, and hereby are, authorized and directed to carry out the recommendations of said report.

The President then read a request from the Board of Directors that the by-laws be so amended as to constitute three members of the Board a quorum, instead of four as was then the case. The reasons for this change were fully stated, and by unanimous vote, Section V, Article II of the By-Laws was amended to read as follows:

"Three members of the Board of Directors shall constitute a quorum, etc."

There being no further business before the meeting it was adjourned.

Herbert WILSON,

Henry H. Elgin,

President.

Secretary.

The publication of notice of meeting, and the appointment of inspectors of election referred to in the above minutes are required by the laws of New York but would be optional in most other states. Publication of notice is quite commonly neglected in the smaller New York corporations.

A record of those in attendance at the meetings of stockholders should be kept by the secretary. In the smaller corporations the names of those present in person or by proxy might appear in the minutes. In the larger corporations a special record is kept.

The resolution in the above minutes authorizing and instructing the board of directors to carry out the committee's recommendations as to plant and equipment is not essential as the board already has power 
to do so without the resolution, and if it saw fit to disregard the stockholders' mandate could not be called to account therefor. It is, however, an expression of the stockholders' wishes and as such has weight with the board. Also not infrequently the board will ask for such an endorsement of any proposed action when of special importance or of great expense in order that the stockholders may share the responsibility.

\section{Form 36.-Regular Meeting of Directors.}

\section{ELLENVILLE WOOLEN MILLS COMPANY.}

\section{Minutes of Regular Meeting of Directors}

Held August 27, 1909.

The Board of Directors of the Ellenville Woolen Mills Company met in regular meeting in the office of the Company at Ellenville, New York, on the 27th day of August, 1909 at 3 o'clock P. M.

President Wilson presided over the meeting and Secretary Elgin recorded its proceedings.

Present, Messrs. Warren, French, Symington and Wilson, constituting a quorum of the board.

The minutes of the previous meeting were read and approved. The minutes of the special meeting of Directors held August I2th, 1909, were also read, but their approval was objected to by Mr. French on account of the statement therein that he had offered a resolution intended to reduce the wages of the Company's employees. Mr. French stated that so far from offering that resolution, he had opposed it and voted against it, and asked that the minutes be corrected in accordance with these facts. There being some difference of opinion as to what actually occurred, the correction asked for by Mr. French was directed by motion, Messrs. Warren and French voting in the affirmative, Mr. Wilson voting in the negative, and the President 
declining to vote. By the same vote the minutes, as corrected, were then ordered approved.

The Treasurer submitted a special report showing the financial condition of the Company and the probable receipts and expenditures for the first quarter of the year. The report was ordered received and filed.

The President then stated that he had in his possession a copy of a report made by a Committee of the Stockholders on the condition of the Company's plant, and making recommendations for its improvement. In connection with this report the President submitted a copy of a resolution passed at the annual meeting of stockholders authorizing and directing the Board of Directors to act in accordance with the recommendations of the aforesaid Committee's report. The report and resolution were ordered received and filed.

The President also reported that the by-laws, as requested by the Board, had been so amended at the recent stockholder's meeting as to constitute three a quorum at meetings of the Directors.

The Board then proceeded to the election of officers. This was by ballot and resulted in the re-election of the old officers of the Company to their respective positions, viz: President, Mr. Herbert Wilson; Treasurer, Mr. Howard Gannett; Secretary, Henry H. Elgin.

The report of the Stockholders' Committee was next taken under consideration, and, after some discussion, Messrs. Wilson and Symington were appointed a Committee to determine the condition of the existing equipment and to ascertain the exact cost of the proposed betterments. Also the President was instructed by unanimous motion to call a special meeting of the Board so soon as this Committee was ready to report, the purpose of such meeting being to receive the report of the Committee and take such action in connection therewith as might seem necessary or advisable.

There being no further business before the meeting it was declared adjourned.

Herbert Willson,

President.

Henry H. Elgin, Secretary. 
Form 37.-Special Meeting of Stockholders.

\section{CARONDELET SILK COMPANY.}

\section{Minutes of Special Meeting of Stockholders Held July 20, 1909.}

Pursuant to formal Call and Notice, the stockholders of the Carondelet Silk Company, assembled in special meeting in the office of the Company, I45 Main Street, Paterson, N. J., at Io o'clock A. M., on the 20 th day of July, I909.

The meeting was called to order by President Gowey, Secretary Harkness officiating as recording officer.

The entire capital stock of the Company was represented at the meeting either in the person of the owner or by proxy.

The stock represented in person was as follows:

$$
\text { Name. Amount. }
$$

Samuel T. Adams.................. I00 shares.

Willis S. Baker.....................

Henry Buchanan ...................100 "

John F. Gowey....................500 "

John T. Harkness................... 100 "

James P. Harmon....................200 “

William Perkins ..................100 "

Sargent P. Wylie.................. "

The stock represented by proxies duly filed with the Secretary was as follows:

Name. Name of Proxy. Amount.

John F. Aldrich...... John T. Harkness, 250 shares.

$\begin{array}{lllll}\text { John B. Goodell..... “ } & \text { " } & \text { " } & \text { r } 50 & \text { " } \\ \text { Weldon P. Hunt..... } & \text { " } & & & \end{array}$

On request of the President, the Secretary presented the Call and Notice pursuant to which the meeting was held. These were ordered entered upon the Minute Book immediately following the minutes of the meeting. 
President Gowey then briefly stated the purpose of the meeting to be the consideration of a proposition from the Cumberford Silk Manufacturing Co. of Paterson, for the purchase of the entire property of the Company, including patents, machinery, realty, stock on hand, book accounts, orders and all other assets of the Company, save cash in bank, and bills and accounts receivable, the object of the purchase being the consolidation of the Cumberford and Carondelet businesses under one management. That, if the proposition were accepted, the Cumberford people would organize a Company with a capitalization of $\$ 750,000$ to take over and operate the two properties, the price offered for the Carondelet property being $\$ 150,000$ in cash and $\$ 150,000$ in stock of the new Company.

In conclusion the President advised strongly the acceptance of the proposition, stating that on account of floods and strikes, from both of which the Company had suffered, the Carondelet Company would be unable to pay the accustomed dividend for 1909; that the future outlook was very uncertain, and that the prospects of a strong Company, such as the Cumberford people proposed to organize, were far better in every way than could possibly be the case with a smaller company; and that for the reasons stated, as well as for others that could not be gone into at that time, he considered the acceptance of the proposition advisable and to the interests of the stockholders.

An extended discussion of the matter followed the President's statement, the opinion being expressed by several stockholders that the proposed consolidation was illegal, and numerous questions being asked President Gowey as to the financial features and other details involved in the proposition submitted.

Finally Mr. Buchanan moved that the meeting be adjourned until Io o'clock A. M. of the following day, in order to give the stockholders time to look into the matter and confer among themselves. The motion was seconded and passed, and the President thereupon declared the meeting adjourned in accordance with said motion.

JоHN F. Gowey,

President.

JoHN T. HARKNEsS, Secretary.

Pursuant to the instructions of the foregoing minutes, the following instruments are entered below: 
Call for Meeting.

Paterson, New Jersey, July 12, 1909.

Mr. JoHn T. HaRKNesS,

Secretary of the Carondelet Silk Co.,

I45 Main St., Paterson, New Jersey.

DEAR SIR-In accordance with the authority vested in me by the by-laws of this Company, I hereby call a special meeting of its stockholders, to be held in the office of the Company, No. I45 Main St., Paterson, N. J., on the 2oth day of July, I909, at Io o'clock A. M., for the purpose of considering and acting upon a proposition to sell the entire assets of the Company, and for the transaction of any and all business in connection therewith that may properly come before said meeting, and I hereby authorize and instruct you to send out notices of said meeting to the stockholders of this Company in accordance with the requirements of its by-laws.

Yours very truly,

JOHN F. GOWEY,

President.

\section{Notice of Meeting.}

Mr. Sargeant P. Wylie,

Paterson, New Jersey,

July I4, I909.

Montclair, New Jersey.

DeAr Sir,-You are hereby notified that, pursuant to the call of the President, a special meeting of the stockholders of the Carondelet Silk Company will be held in the Company's office, No. I45 Main Street, Paterson, New Jersey, July 20th, 1909, at Io o'clock A. M., for the purpose of considering and acting upon a proposition to sell the entire assets of the Company, and for the transaction of any and all business necessary or desirable in connection therewith.

Yours very truly,

JoHN T. HARKNESS,

Secretary. 


\section{Form 38.-Adjourned Meeting of Stockholders.}

\section{CARONDELET SILK COMPANY.}

\section{Minutes of Adjourned Meeting of Stockholders}

Held July 2I, 1909.

Pursuant to adjournment, the special meeting of the stockholders of the Carondelet Silk Company reassembled in the office of the Company at Io o'clock A. M. on the 2ist day of July, I909.

The meeting was called to order by President Gowey, with Secretary Harkness officiating as recording officer.

The stockholders of the Company were all present in person save Messrs. John F. Aldrich, John B. Goodell and Weldon P. Hunt, who were represented by proxies in the hands of Secretary Harkness.

The minutes of the special meeting of stockholders held on the preceding day, and from which the present meeting was adjourned, were read for the information of those present.

After the reading of the minutes, Mr. Buchanan offered the following resolution:

Whereas, A proposition has been made by the Cumberford Silk Manufacturing Company of Paterson for the purchase of the entire property of this Company, save cash in bank, and bills and accounts receivable, the consideration offered being One Hundred and Fifty Thousand $(\$ 150,000)$ Dollars in cash and One Hundred and Fifty Thousand $(\$ 150,000)$ Dollars face value of stock in a certain new corporation to be formed for the purpose of taking over the business and properties of the two Companies; and

Whereas, The stockholders of this Company are favorably impressed with said proposition, but believe that a full legal investigation of the whole matter should be made before proceeding further:

Now, Therefore,Be It Resolved, That the stockholders of this Company hereby instruct and authorize the Direc- 
tors of the Company to employ such competent legal assistance as may be necessary to investigate and report upon said proposition in all its phases, and, if such investigation shall show that there are no legal objections to the contemplated sale, to accept the said proposition and to do all things necessary to carry such acceptance into effect.

Mr. Buchanan then moved the adoption of the resolution as read. The motion was seconded by Mr. Adams, and, after a short discussion, was carried by the unanimous vote of all present.

There being no further business before the meeting, the President declared it adjourned sine die.
ЈонN F. GOWEY,
President.
JoHN T. HARKNESS,
Secretary.

\section{Form 39.-Special Meeting of Directors.}

\section{ELLENVILLE WOOLEN MILLS COMPANY.}

\section{Minutes of Special Meeting of Directors}

Held September 3, r909.

Pursuant to call of the President, the Board of Directors met in special meeting, in the office of the Company, September 3, 1909, at II o'clock A. M.

The meeting was called to order by President Wilson, Secretairy Elgin acting as recording officer.

All members of the Board were present.

The Secretary presented the call of the President and a copy of the notice pursuant to which the meeting was held. There being no objection, the President ordered the Call and Notice to be spread upon the Minute Book immediately following the minutes of the present meeting. (See Forms 30, 3I.)

The President then stated that the meeting had been called to hear and act upon the report of the Committee appointed 
August 27, 1909, to investigate the cost of proposed betterments to the plant of the Company.

Upon request of the President, Mr. Symington presented and explained the report of the Committee. This showed that the proposed improvements to the Company's plant could not be made for less than $\$ 60,000$, but brought facts and figures to show that this expenditure was not only justified, but was essential to the Company's continued prosperity.

Upon motion the Committee's report (See Form 76) was ordered received and filed and the Committee discharged with the thanks of the Board.

The Treasurer of the Company, who was present by request of the President,then submitted a report showing that some $\$ 30,000$ in surplus and undivided profits was available for the proposed improvements. $\mathrm{He}$ also stated that the balance required could be secured on very favorable terms.

Mr. Symington stated that the investigation conducted by the Committee had convinced him that the reduced cost and better quality of the Company's output under the improved conditions would so increase the annual profits as to enable the Company to pay the entire deferred obligation within a year from the date of the installation, a position in which he was sustained by the report of the Stockholders' Committee submitted to the Board at the preceding meeting.

After a short further discussion, the President was, by motion unanimously carried, instructed to secure bids from Messrs. Meldrum \& Kinney for the alterations of the buildings and the new constructions necessary to accommodate the improved equipment, and to secure working estimates from the Miller Machine Co. of Pawtucket, Rhode Island, on the cost of the required new equipment and the expense of its installation, these bids and estimates to be ready for submission to the Board not later than the rith day of September, 1909.

Upon motion, unanimously carried, the Board then adjourned until the I3th day of September, 1909, at Io o'clock A. M.

Herbert Wilson,

President.
Henry H. Elgin, Secretary. 


\section{CHAPTER XXVI.}

\section{MOTIONS AND RESOLUTIONS.}

In a meeting of either stockholders or directors, anything of minor importance, or obviously necessary, as the correction of a name or a date in the records, or the approval of the minutes of a previous meeting, might be merely directed by the president, and, if not objected to by those present, would be held to be the action of the meeting. In matters of more importance, however, or on which there is a difference of opinion, the action of the meeting must be more formally expressed and the motion or resolution is then employed.

Motions and resolutions are of the same force and both are legal and recognized methods of determining the will of an assemblage. They differ, however, in form, in the degree of their formality, and, in a general way, in the matters in which they are employed.

There is no clear-cut separation between the actions that should be taken by motion and those that are better taken by resolution, but it may be stated as a general rule that important matters should be authorized by resolution, while matters of less importance are left for motions.

The motion is the simplest method of formal corporate action. Being designed to cover matters of 
the moment, motions are not as a rule submitted in writing. If, however, the subject is complex or important, or if it is desirable that exact, or a precise wording be preserved, the motion should be presented in writing, or if not so presented, the presiding officer should request the maker of the motion to reduce it to writing. The written copy is then handed to the president or to the secretary, and, if the motion is carried, is incorporated verbatim in the secretary's minutes. If the motion is not written, the secretary must exercise every care to get the sense of what is intended, and follow the wording of the maker so far as is practicable.

The following forms of motions are as they would appear in the secretary's minutes. The form of motion is the same for either stockholders' or directors' meetings. The general wording of the entry will vary with the circumstances.

\section{Form 40.-Motion. To Receive and File Report.}

"Upon motion duly seconded and unanimously carried, the Treasurer's Report, as read, was ordered received and filed."

Form 4I.-Motion. To Pay Bills.

"Upon motion, duly made and seconded, and unanimously carried, the Treasurer was directed to pay the bills, as presented to the meeting, for October rent and salaries."

Usually the secretary is left to his discretion as to 
whether the names of the parties making and seconding a motion are entered, or otherwise. In the foregoing motions, authorizing routine action and concurred in by all, the names are not essential. In any matters where there is a difference of opinion, or a likelihood of subsequent discussion or trouble, the names of the maker and of the party seconding a motion should be recorded. In matters of much importance the vote is frequently recorded as well.

\section{Form 42.-Motion. To Pay Disputed Account.}

"Mr. William Morris moved that the account of the ShirleyWilson Company for supplies furnished, aggregating $\$ 235.00$, be paid in full. Motion seconded by Mr. H. M. Shepherd and carried, Messrs. Morris, Shepherd and McKane voting in the affirmative and Messrs. Temple and Stanford voting in the negative."

If, in the case of a specially complicated or important motion, the maker were requested to put it in writing, the following form would be suitable.

\section{Form 43.-Motion. To Purchase Engines.}

"Moved, That the President of this Company be hereby directed to fully investigate the claims of the Simplex Corliss Automatic Engines represented by the Willis \& Vrooman Co., and, if such engines prove, in his judgment, materially more efficient-under equal conditions-than the engines now in use in the shops of this Company, that the officers of the Company shall thereupon exchange said present engines for an equal $\mathrm{H}$. P. capacity of the Simplex Corliss Engines, provided that the expenditure necessitated by such exchange shall not exceed the sum of $\$ 650.00 . "$ 
This motion should be handed the president by the maker as soon as written out, and be read by that officer to the meeting. If duly seconded, the motion would, after discussion, be put to the vote, and, if carried, the written copy be handed to the secretary for his records. The secretary should incorporate such written motion into his minutes without change of any kind, prefacing it with the proper explanatory statement, as, "The following motion, offered by Mr. Brown, was duly seconded, and carried by the unanimous vote of all present."

Resolutions are more formal than motions, usually go into their subject more fully, and are used for such important corporate actions as require a complete statement and record. Resolutions should always be submitted in writing, and should be entered in the secretary's minutes exactly as adopted. Resolutions are usually adopted by motion. Routine resolutions, such as those which immediately follow, do not require any statement of the exact vote, but are entered in the minutes, prefaced with the requisite explanatory remarks; as, for example, "Upon motion of Mr. Castleton, duly seconded by Mr. Elliott, the following resolution was unanimously adopted." (See § 88.) [1]. 1 . 1:

\section{Form 44.-Resolution Authorizing Contract.}

\section{(Directors'.)}

Resolved, That the President and Secretary of the Corwin Manufacturing Company be and hereby are authorized and directed to enter into a contract in the name of, and on behalf 
of said Company with Henry J. Wilkins of the City of New York for the erection of a brick boiler house, the construction of such house to be in accordance with the plans and specifications now on file in the office of this Company, and the price and terms of payment therefor to be in accordance with the written propositions submitted by said Henry J. Wilkins.

This is the proper method of authorizing the officers of the company to close a contract and to bind the corporation by its signature and seal. Form 58 shows the introductory paragraph and the closing paragraph, or testimonium, of the contract which the officers execute in pursuance of the foregoing resolution. (See $§ 98$.

\section{Form 45--Resolution Declaring Dividend.}

(Directors'.)

RESolved, That the sum of Two Thousand $(\$ 2,000)$ Dollars be and hereby is appropriated and set aside from the surplus profits of this Company for the payment of the regular two per cent. quarterly dividend upon its outstanding stock, said dividend to be due and payable on the roth day of August, I9og.

Resolved Further, That the Treasurer of this Company be and hereby is authorized and instructed to notify the stockholders of such dividend and to pay the same when due.

The passage of this resolution places the whole matter of the declared dividend in the hands of the treasurer. He will charge off its total amount from profits to dividend account, will send out notices of the dividend at the proper time and will prepare and deliver to the stockholders checks for the amounts due. 


\section{Form 46.-Resolution Authorizing Sale of Assets. (Stockholders'.)}

Whereas, A certain proposition has been made by Wm. F. Gaynor and Jas. P. O'Reilly, as Trustees for the organization of the New Hampshire Granite Company, to purchase the entire plant, business and other assets of this Company, save cash in bank, for Ten Thousand $(\$ 10,000)$ Dollars in cash and forty Thousand $(\$ 40,000)$ Dollars par value of the stock of the said New Hampshire Granite Company; and

Whereas, Said proposition is approved by the stockholders of this Company:

Now, Therefore, Be It Resolved, That the Directors of this Company be, and hereby are, authorized, instructed and empowered to accept said proposition for the purchase of its said business and assets, and to do all things necessary to carry such acceptance into effect according to the terms of said proposition.

In most states the directors can not dispose of the entire assets of a solvent corporation save with the consent of all the stockholders. Under such conditions the preceding resolution must be adopted by the unanimous vote of the entire outstanding stock of the company if it is to be effective.

It is probable that in the negotiations that follow a certified copy of this resolution will be required. In such case the secretary's certification should state that the resolution was adopted by unanimous vote of all the outstanding stock, or an extract might be made from the minutes including the resolution and the circumstances of its adoption. If the latter method were adopted the secretary would merely certify to the correctness of the quotation from the minutes. (See Forms 52-54.) 


\section{CHAPTER XXVII.}

\section{SIGNATURES AND CERTIFICATIONS.}

\section{Form 47.-Official Signatures.}

(a) Henry W. Stanton,

President. (b) Henry W. Stanton, President American Machine Works.

Signatures such as the above where the official signing employs his own name followed by his official title, are termed official signatures. They are used in signing letters and unimportant papers which pertain to matters in charge of the particular official. The second form should be employed unless, by letter heading, subject matter, or in some other way, the company of which the signing party is an official is unmistakably indicated.

Form 48.-Corporate Signatures.

(a) The Ransome Wheel Company, By

President. 
(b) The Ransome Wheel Company,

By John M. Wells, President.

(c) Attest Seal,

Henry T. Wilkins, Secretary.

(d) In Witness Whereof, the said Maxwell Investment Company has hereunto caused its corporate name to be signed by its President and its corporate seal to be affixed by its Secretary, all being done in the City of New York on this I7th day of October, 1909.

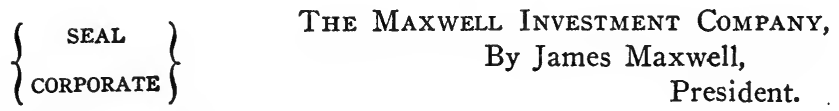

Attest Seal:

Casper Germain,

Secretary.

The first of these forms (a) shows a partial corporate signature awaiting completion by insertion of the president's signature as shown in (b). The portion of the signature shown in (a) is usually impressed with a rubber stamp. Any other official of the company might affix the corporate signature with equal propriety, if authorized thereto, or might join with the president in such signature. The form for attestation of seal is shown in (c). In (d) is shown a formal corporate signature complete, affixed to the testimonium-or final clause - of a corporate contract. Had the secretary joined with the president in the corporate signature as in Form 58, no attestation of the seal would have been necessary. (See $\S 97$. ) 


\section{Form 49.-Corporate Endorsements.}
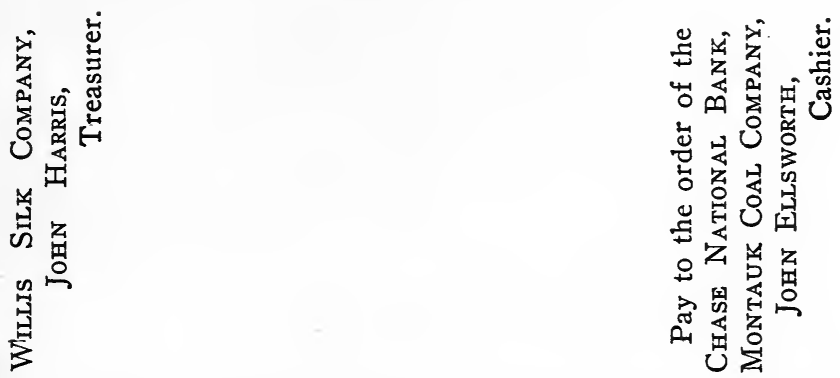

The first of these is the simple corporate endorsement. The second is the form usually employed when the instrument is deposited for collection or credit. This latter endorsement is generally affixed in its entirety with a rubber stamp.

A corporation does not acknowledge signatures, or the execution of instruments, in its own name, but only through its officers. Each state has its own form for such acknowledgments. The following meets the New York requirements.

Form 50.-Acknowledgment of Corporate Instrument.

State of New YoRK, County of New York, $\}$ ss.:

On the twelfth day of August, in the year 1909, before me personally came Henry Willis Crampton, to me known, who, being by me duly sworn, did depose and say that he resides in the City of New York; that he is the president of the Crampton Shipbuilding Company, the corporation described in and which executed the above instrument; that he knows the seal of said 
corporation; that the seal affixed to said instrument is such corporate seal; that it was so affixed by order of the Board of Directors of said Corporation, and that he signed his name thereto by like order.

Sworn to before me this

Henry Willis Crampton.

12th day of August, 1909.

$\left\{\begin{array}{c}\text { Notarial } \\ \text { SEal }\end{array}\right\} \begin{gathered}\text { Henry Silliman, } \\ \text { Notary Public for } \\ \text { New York County. }\end{gathered}$

\section{Form 5r.-Treasurer's Affidavit.}

$\left.\begin{array}{l}\text { State of New York, } \\ \text { County of New York. }\end{array}\right\}$ ss.:

On this 15th day of August, 1909, personally appeared before me, a Notary Public in and for the County of New York, William H. Holt, Treasurer of the Merriman Wrecking Company, who, being duly sworn, did depose and say that he has full charge and control of the books and accounts of the said Company; that the above and foregoing statement is taken from said books and accounts; that it is a true and accurate transcript therefrom, and that, to the best of his knowledge and belief, it is a just and correct presentation of the financial condition of said Company on this date.

Sworn to before me this

William H. Holt.

I5th day of August, I909.

$\left\{\begin{array}{c}\text { NOtarial } \\ \text { SEal }\end{array}\right\} \begin{gathered}\text { Henry Silliman, } \\ \text { Notary Public for } \\ \text { New York County. }\end{gathered}$

\section{Form 52.-Certified Resolution for Bank.}

Certified Resolution.

"RESOLVED: That the Treasurer be and hereby is authorized and instructed to open an account for the Com- 
pany with the Seventh National Bank of Rochester and to deposit therein all the funds of the Company coming into his custody; such account to be in the name of the company, and funds deposited therein to be withdrawn only by check signed by the Treasurer and countersigned by the President."

I hereby certify that the foregoing is a true and accurate transcript of a resolution duly passed at a regular meeting of the Board of Directors of the Mallibone Manufacturing Company held in the office of said Company in Rochester, New York, at II o'clock A. M., on the Ioth day of September, 1909, as shown by the minutes of said meeting; and that Charles Mallibone is the duly elected President of said Company and Henry Cornell is the duly elected Treasurer of said Company.

In Testimony Whereof, I have hereunto affixed my offcial signature and the corporate seal of said Company, this Ioth day of September, 1909.

$\left\{\begin{array}{c}\text { CORPORATE } \\ \text { SEAL }\end{array}\right\}$

Henry Compton, Secretary.

The above is a good general form employed in opening the corporate bank account. In many cases the banks have their own forms for this purpose and if so these special forms will, of course, be used.

In some cases banks require also a certified transcript of any by-laws relating to the custody of funds and the duties of officers in relation thereto.

The clause certifying to the identity of the president and treasurer in the above certification is not a necessary feature of a certification but merely adds information for the bank required in the present instance. 


\section{Form 53.-Certified Extract from Minutes.}

\section{HINCKLEY CONSTRUCTION COMPANY.}

Transcript From Minutes

of

Regular Meeting of Directors held September 15, 1909.

(Transcript from minutes appears here.)

I, the undersigned, Secretary of the Hinckley Construction Company, do hereby certify that the above and foregoing is a true and accurate transcript from the minutes of a regular meeting of the Board of Directors of said Company held in the office of the Company on the I5th day of September, 1909, and recorded on pages 85 to 87 of the Minute Book of said Company.

Witness my hand and the seal of the Company this I4th day of October, I909.

$\left\{\begin{array}{c}\text { CORPORATE } \\ \text { SEAL }\end{array}\right\}$

Frank McCall, Secretary.

\section{Form 54.-Certified Extracts from Minutes. Formal.}

We, the undersigned, President and Secretary respectively of the Hinckley Construction Company, do hereby certify that the above and foregoing is a true and accurate transcript from the minutes of a regular meeting of the Board of Directors of said Company held in the office of the Company on the $15^{\text {th }}$ day of September, I909, and recorded on pages 85 to 87 of the Minute Book of said Company.

In Witness WhEREOF, we have hereunto affixed our official signatures and the seal of the Company in the City of Saratoga, State of New York, on this I4th day of October, 1909.

$\left\{\begin{array}{c}\text { CORPORATE } \\ \text { SEAL }\end{array}\right\}$

Hamilton Hinckley, President.

Frank McCall,

Secretary. 
CHAPTER XXVIII.

CHECKS, NOTES AND CONTRACTS.

Form 55.-Corporate Check.

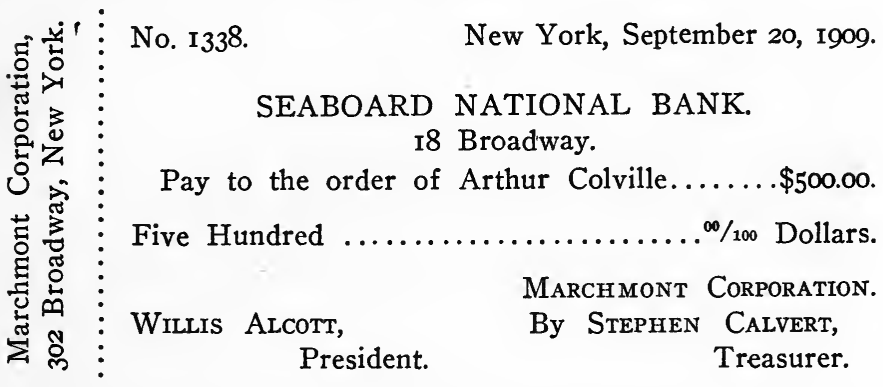

Checks are made out in a variety of forms. The above form is much used. Occasionally the draft form is employed, the name of the company appearing in the place occupied by the bank's name in the foregoing check form, and the name and address of the bank appearing in the left lower corner. The arrangement has merits from an advertising standpoint. If a check has the name of the company plainly appearing upon it, the simple official signatures of the officers authorized to sign, as given in Form 47 (a), are much used, though it is perhaps better that the corporate signature should appear. Any signature recognized by the bank is, however, sufficient. 
Form 56-.Corporate Note. Signature by President.

$\$ 1,000.00$.

New York, August 16, 1909.

Sixty days after date the Ogden Wrecking Company promises to pay to the order of Henry Adams the sum of One Thousand dollars.

Ogden Wrecking Company, By Henry Ogden, President.

The foregoing gives the proper form of signature for a corporate note. If the foregoing note were merely signed with the president's official signature,"Henry Ogden,

President of the

Ogden Wrecking Company."

the person so signing might make himself personally liable and might also invalidate the note as against the corporation.

Form 57.-Corporate Note. Signature by Treasurer.

$\$ 1,500.00$.

Newark, New Jersey, October I, I909.

Three months after date the Harwood Manufacturing Company promises to pay to the order of Howard McCormick the sum of Fifteen Hundred Dollars, with interest from date until paid, at the rate of Five Per Cent. per annum.

Value received.

The Harwood Manufacturing Company, By James H. Halsey,

Payable at the Treasurer.

Seaboard National Bank of New York City.

A corporate note does not require to be sealed. It may be signed by any officer or officers properly auth- 
orized thereto. For notes given in the regular routine of business, this authority would usually be conferred upon the proper officials by the by-laws or by custom. For large amounts, or for special transactions outside the usual routine, this authorization would be given by resolution or motion of the board of directors.

\section{Form 58.-Corporate Contract.}

\section{CONTRACT.}

This Agreement, made and entered into this 23rd day of September, 1909, by and between the Corwin Manufacturing Company, a corporation duly organized and existing under the laws of the State of New York, party of the first part, and Henry J. Wilkins, of the City and State of New York, party of the second part:

WITNESSETH :

That in consideration of the, etc.

(Here would be inserted the consideration, specifications and terms.)

In Witness Whereof, the said Corwin Manufacturing Company, party of the first part, has caused its corporate seal to be hereunto affixed and its corporate signature to be subscribed hereunto by its President and Secretary, and the said Henry J. Wilkins, party of the second part, has hereunto affixed his signature and seal, all being done in the City and State of New York on the day and year first above written.

Corwin Manufacturing Company,

$\left\{\begin{array}{c}\text { CORPORATE } \\ \text { SEAL }\end{array}\right\}$

By Wilson M. Brown, President.

Hariey B. Small, Secretary.

In presence of:

HenRy J. Wilkins. [L. S.]

Manly F. Clark.

Albert Parsons. 
When the secretary joins in the company signature as in the foregoing form, he need not attest the seal. If, however, he does not join in the company signature, the corporate seal should be attested by his signature and the formal corporate signature affixed to the foregoing testimonium would then appear as in Form 48.

Where the contract or other instrument is to be acknowledged for record in some particular state, the form of acknowledgment used in that particular state should be employed, or, in the case of real estate, the form used in the state in which the real estate is situated. (See Form 44 for resolution authorizing this contract.)

\section{Form 59.-Assignment of Contract.}

\section{Assign ment.}

Know All Men By These Presents:

That for and in consideration of the payment by the Allegheny Coal Company, a corporation duly organized under the laws of the State of West Virginia and having its principal office and place of business at 275 Main Street, Cornwallis, West Virginia, of Seven Thousand Two Hundred and Forty-seven $(\$ 7,247.00)$ Dollars to the Consumers Coal Company, a corporation duly organized under the laws of the State of New York, and having its principal office and place of business at 54 Broadway, New York City, the receipt of which payment is by the last-named corporation hereby acknowledged, said Consumers Coal Company does hereby assign, transfer and convey to the said Allegheny Coal Company, all and singular, its right, title and interest of every kind in and to a certain contract, copy of which is hereunto annexed and made part of this instrument, entered into on the I3th day of August, 1909, between the Empire Steam \& Power Company of New York City 
and the said Consumers Coal Company, for the delivery to said Empire Steam \& Power Company of Forty-five Thousand $(45,000)$ Tons of bituminous coal, at the price and of the grade and upon the terms set forth in said contract, which said contract is hereby conveyed to and accepted by the said Allegheny Coal Company subject to all the terms and conditions therein set forth, and it is a further condition of this assignment that the said Consumers Coal Company shall be free from any claim, liability or other obligation for, on account of, or by reason of said contract.

In Witness Whereof, the said Consumers Coal Company has hereunto caused its corporate name and seal to be affixed by its President and Secretary, all being done in the City of New York on this I3th day of August, roog.

$\left\{\begin{array}{c}\text { CORPORATE } \\ \text { SEAL }\end{array}\right\}$

Consumers Coal Company,

By Charles Stevenson,

President.

William Crosby,

Secretary. 


\section{CHAPTER XXIX.}

\section{THE CORPORATE RECORDS.}

The stock ledger on opposite page combines in compact form all the requisites of the stock ledger with all the statutory requirements of most of the states as to the stock book.

The leaves of the book are indexed to secure the necessary alphabetical arrangement, and the name and residence of the stockholder appear at the head of the account as in the ordinary ledger. On the right-hand side of the account the party is credited with the stock he purchases or otherwise acquires, and on the lefthand side is debited with any stock disposed of. The difference between the two sides shows at any time the amount of stock standing to his credit.

On the debit or sales side of the account, the first column gives the date of the transaction, the second the name of the party to whom the stock is transferred, the third the number of the surrendered certificate, the fourth the number of the certificate reissued to the transferrer, in case but a portion of the stock represented by the surrendered certificate is sold, and the fifth column the number of shares disposed of. 
THE CORPORATE RECORDS.

263

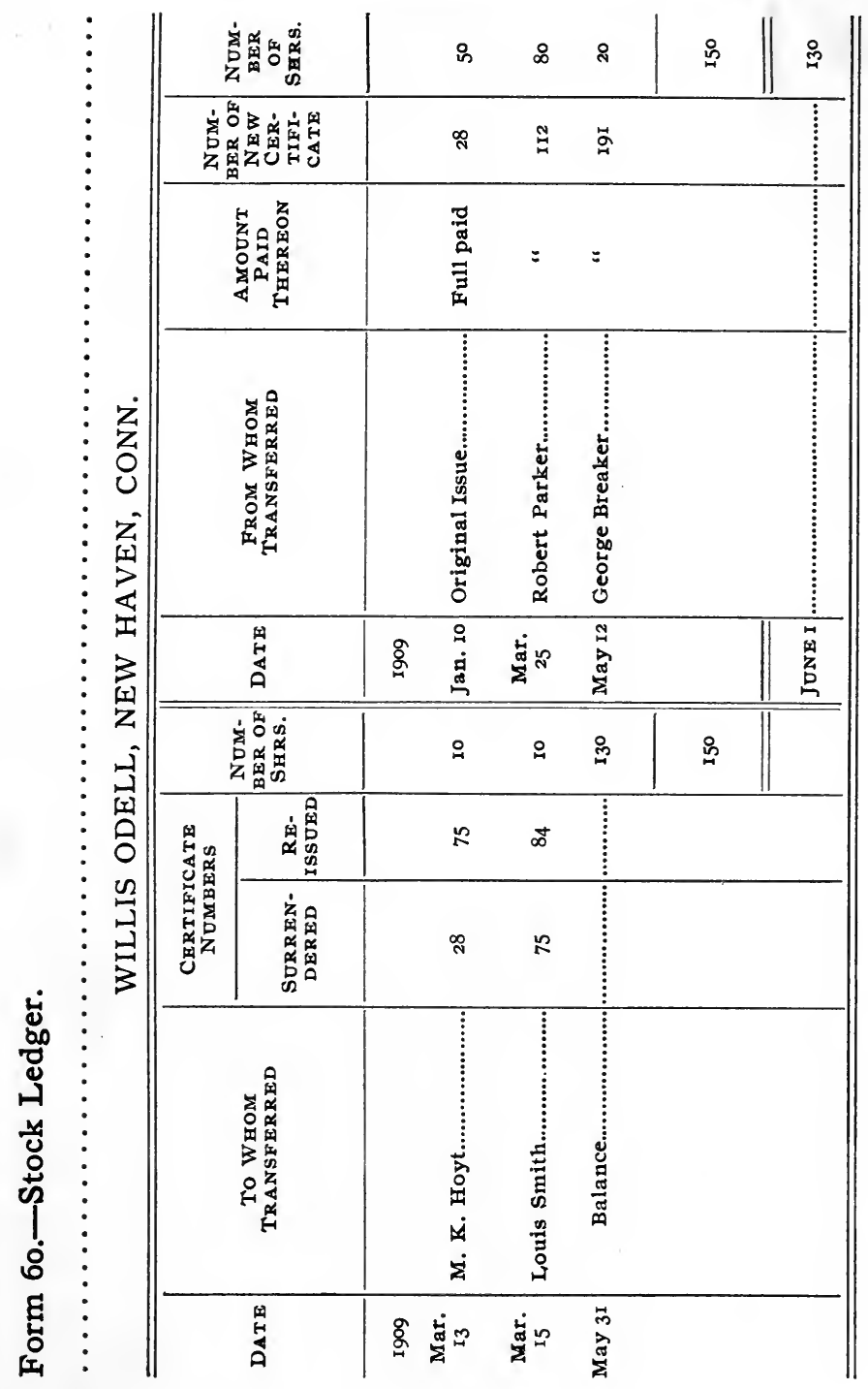


On the credit side, the first column gives the date of purchase, the second the name of the party assigning the purchased stock, the third the character of the stock, whether full-paid or but part-paid, and if but part-paid the amount paid to the company thereon, the fourth column the numbers of the certificates issued to the party, and the last the number of shares acquired. (See $\S \S 46,9$ I.)

\section{Form 6r.-Transfer Book.}

Ledger Folio 25.

Transfer No. 725 .

THE HASWELL PAPER PULP COMPANY.

For Value Received, I hereby sell, assign and transfer to Harvey Woodville, of Brooklyn, New York, Fifteen (I5) Shares of the Capital Stock of the above-mentioned Company now standing in my name on the Company books and represented by surrendered Certificates, Nos. 32 and 153 .

Witness my hand and seal this I2th day of July, r909, at Jersey City, New Jersey.

\section{EDWARd SERRELl,}

By Holmes B. Desbrow,

New Certificates Nos. 325, 326. Attorney. Issued to Harvey Woodville. Ledger Folio 75.

The secretary or transfer agent usually acts as attorney for the person selling the stock, and fills out and signs the transfer as shown above. The data relating to the issue of the new certificate is no part of the transfer proper, being merely a memorandum for the convenience of the secretary when making the entry of the transfer in his stock book. (See $\S \S 46,90$.) 
THE CORPORATE RECORDS.

265

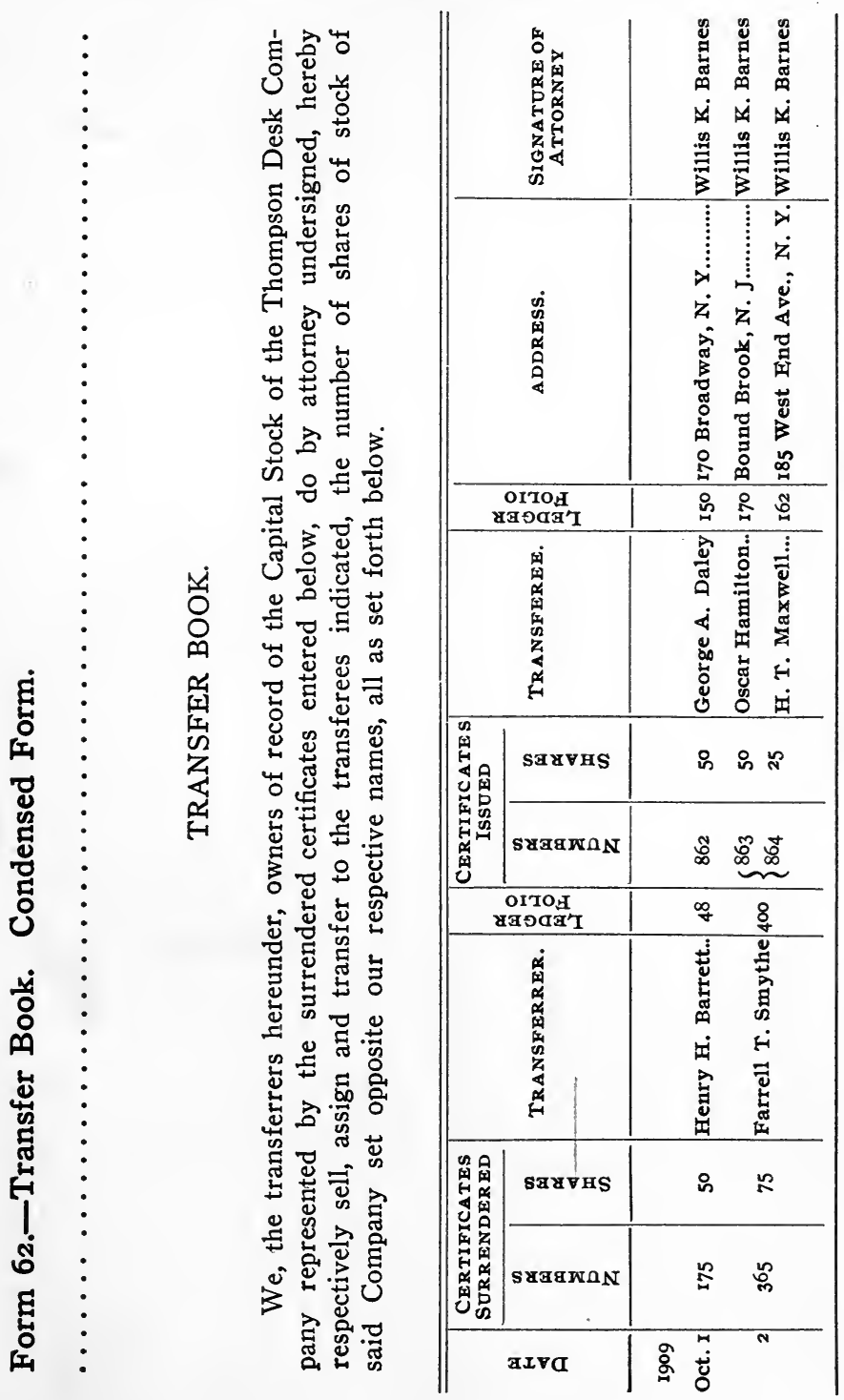


The transfer book is usually closed to transfers from ten to twenty days before the annual meeting, as may be prescribed by the by-laws. During this period no transfers of stock will be entered on any of the books of the corporation.

Another form of transfer book used by the larger corporations is given in Form 62. This shows the upper portion of the page. The blanket assignment at top enables the record of each transfer to be made on a single line. The convenience of the form where transfers are frequent is obvious.

In the entries shown the second transferrer has surrendered a single certificate for seventy-five shares to be issued to two different parties, and two partial entries are therefore necessary.

\section{Form 63.-Dividend Book.}

DIVIDEND BOOK.

Dividend No. 5 of $2 \%$. Declared Nov. I. I909. Payable Dec. 15, I909, to Stockholders who appear of Record Dec. I, I909.

\begin{tabular}{|c|c|c|c|c|}
\hline $\begin{array}{c}\text { STOCKHOLDER'S } \\
\text { NAME }\end{array}$ & 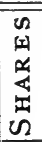 & 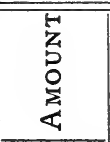 & $\stackrel{Q}{\overbrace{4}^{4}}$ & Received By \\
\hline $\begin{array}{l}\text { Alsop, John H....... } \\
\text { Barrington, Harvey }\end{array}$ & $\begin{array}{l}50 \\
25\end{array}$ & $\begin{array}{r}\$ 100.00 \\
50.00\end{array}$ & $\begin{array}{l}\text { Dec. } \text { I } 8 \\
\text { Dec. } \text { I5 }\end{array}$ & $\begin{array}{l}\text { John H. Alsop. } \\
\text { Howard Jones, Atty. }\end{array}$ \\
\hline
\end{tabular}

The dividend book is employed when stockholders are required to call in person and receive and receipt for dividends. Each dividend as declared is entered 
in detail, occupying one or more pages, as may be necessary. A statement of the facts appears at the head of each page of the particular record. The form as presented is simple and its method is obvious. Stockholders' names are arranged alphabetically, and the signatures appearing in the last column serve as a receipt for the dividend payment. A signature by an attorney, as in the second example, is not sufficient unless authorized by due power of attorney filed with the treasurer of the company. 


\section{CHAPTER XXX.}

\section{NOTICES.}

Subscriptions are frequently made payable in instalments, either at fixed dates, or subject to call. When payable at fixed dates, notice of each instalment when due is sent out by the treasurer. When subject to call, action of the board is necessary before the instalment is due. The following notice is of an assessment made by the board.

Form 64.-Instalment Notice.

Instalment Notice.

YOUMAN COPPER COMPANY.

635 State St., Boston, Mass.

Mr. John H. Mallard, 225 Mill Street, Lowell, Mass.

DEAR SIR,-You are hereby notified that by due resolution of the Board of Directors, the second instalment of Fifteen (15\%) Per Cent. on subscriptions to the stock of the Youman Copper Company has been called for, the amount thereof to be paid to 268 
NOTICES.

the Treasurer of the Company on or before the Ioth day of October, 1909.

Boston, Mass.,

WALFORD H. McMASTERS,

Treasurer.

October Ist, 1909.

Shares Subscribed, 35. Amount of Assessment, \$525.

Draw Checks Payable to Treasurer.

In the smaller corporations dividend notices are usually sent by mail but are not published. In the larger corporations they are almost invariably published and are usually sent by mail as well.

The following is a common form of mailing notice. It may easily be modified for publication purposes by omitting the complimentary address and changing the introductory words to read: "Notice is hereby given."

Form 65.-Dividend Notice. Mailing.

\section{MILL SUPPLY COMPANY.}

646 Broadway, New York.

September I, I909.

DEAR Sir,-You are hereby notified that the Directors of the Mill Supply Company have this day declared the regular semiannual dividend of Four (4\%) Per Cent. on the Capital Stock of the Company, payable October I, I909, to stockholders who appear of record at the close of business September I5, 1909.

Frank T. Schwartz,

Treasurer. 
If, as is usually the case with the larger corporations, the transfer books are closed preparatory to payment of dividends, the dates of closing and reopening should appear as in the following notice, which may be used either for publication or for mailing.

Form 66.-Dividend Notice. Publication.

SUSQUEHANNA COAL COMPANY.

New York, October I, I909.

Dividend No. 40.

The Directors of the Susquehanna Coal Company have this day declared a quarterly dividend of One and One-half ( $\mathrm{I} / 2 \%)$ Per Cent. on the Capital Stock of the Company, payable October 30,1909 , to stockholders of record at the close of business October I0, I909.

Transfer books will close October I0, 1909, and reopen October 19, 1909. Checks will be mailed.

Samuel T. Hinckle,

Treasurer.

When a corporate election is held it is the duty of the secretary to notify the officers-elect. The following is a common form of notification:

Form 67.-Notice of Election as Director.

TRENTON POTTERIES COMPANY.

Trenton, New Jersey.

Mr. Willis T. Smalley,

September 10, 1909.

742 Riverside Ave., Trenton, New Jersey.

DeAr SIR,-You are hereby notified that at the annual meeting of the Trenton Potteries Company held this day, you were elected a member of its Board of Directors. 
The next regular meeting of the Board will be held in the office of the Company September I5, 1909, at 3 o'clock P. M., for the election of officers and for the transaction of such other business as may come before the meeting.

You are requested to be present and participate in this meeting. Respectfully,

\section{Frank Schwingle,}

Secretary.

As a rule, when a director is to be elected, those interested ascertain in advance that the proposed candidate will serve if elected. In such case the notification given above is all-sufficient. If, however, there is any doubt, the notification should request the director-elect to indicate his acceptance, as in the following form :

Form 68.-Notice of Election as Director. Acceptance Requested.

PENN MACHINE WORKS.

763 Chestnut Street, Philadelphia, Pennsylvania.

Mr. JoHN T. French,

October I, I909. 936 Walnut St.,

Philadelphia, Pa.

DeAr SIR,-At a meeting of the Directors of the Penn Machine Company held this day, you were elected a member of the Board to fill the vacancy caused by the resignation of Mr. Henry Simonson. Will you kindly indicate your acceptance of the position at your early convenience.

Respectfully,

GeORGE H. WRight, Secretary. 


\section{CHAPTER XXXI.}

\section{SUNDRY CORPORATE FORMS.}

BALLOTS.

Form 69.-Ballot. Annual Meeting.

BALLOT.

HARRIS DROP-FORGE COMPANY.

Annual Meeting, August ro, 1909.

I, the undersigned, hereby vote 35 shares of stock for the following named persons to serve as Directors for the ensuing year:

Frank T. Harris.

John J. Wilson.

H. Thomas Parkes.

Nelson Brown. Henry Sterling.

Signature,

Francis McСomb, Proxy for John McCallum.

When a ballot is cast by a proxy, the form of signature should include both the name of the proxy and of the party for whom he is acting and indicate the capacity in which the proxy acts. As no question of personal responsibility enters in, the proxy may, on behalf of his principal, affix his own signature, as in 
the foregoing example, or may, as proxy, sign his principal's name thus,-

$$
\begin{aligned}
& \text { "John McCallum, } \\
& \text { By Francis McComb, } \\
& \text { Proxy." }
\end{aligned}
$$

If cumulative voting is used, a different form of ballot is necessary. The following meets the requirements :

Form 6ga.-Ballot. Cumulative Voting.

\section{BALLOT. \\ METALS-ALLOY COMPANY. \\ Annual Meeting, January 12, 1909.}

I, the undersigned, hereby vote for the following named persons to serve as Directors for the ensuing year, casting for each the number of votes set opposite his name:

NAME.

VOTES CAST.

John J. Niles.........................

Frank Berrian...................... 25

Signature,

Number of Shares Owned.... 50

Howard S. Benjamin.

Number of Votes Cast.....250

(See $\S \S$ II2, I35.)

Resignations.

It is obvious that an elective officer can not be forced to retain his position against his will. Hence a director or other officer of a corporation may resign at any time. 
A resignation may be so phrased as to be immediately effective without acceptance, or otherwise may be worded so as to be ineffective until accepted by the board of directors. The following resignation is of this tentative nature, requiring acceptance before the official tenure of the party submitting it is terminated.

Form 70.-Resignation of Director.

To the Board of Directors of the

Kron Manufacturing Company.

Gentlemen,-On account of continued ill health, which prevents my attention to the duties of the position, I hereby tender my resignation as a Director of the Kron Manufacturing Company.

New York City,

Very Respectfully,

ROBERT H. McPherson.

September I5, I909.

A tender of resignation such as the foregoing holds good until it is accepted, or until it is withdrawn, or until the party's official term expires. If the resignation is accepted, the whole matter is thereby closed, but at any time prior thereto the party filing the resignation has a right to withdraw it or revoke it, and its acceptance thereafter by the board would be of no effect. Also if the party's official term expires, the resignation is thereby voided and if he is again elected the old resignation, even though still on file, is of no effect. 
It is to be noted that a tentative resignation such as the foregoing, if accepted without qualification is immediate in its effect, the official position of the party signing the same terminating at the moment the resolution or motion of acceptance is adopted. If the party is present at the meeting and it is desirable to avoid this abrupt termination of his official status, the acceptance may be phrased, " to take effect at the close of the present meeting."

A resignation may be made effective at some future date and its prior acceptance can not in any way hasten this date, though it effectually prevents the withdrawal or revocation of the resignation thereafter. It should be remembered that the board can only fill vacancies. Hence, even though a resignation effective at some future date is accepted, a successor to the resigning director can not be elected until the vacancy actually exists. Under no circumstances can the retiring director vote for his own successor.

The following resignation is peremptory and effective as soon as handed to the secretary of the company. No action of the board is required, nor can the board in any way prevent its effect. The peremptory form of resignation is often employed when a director or other official wishes to express his disapproval of, or escape responsibility for some proposed corporate action. It does not relieve the resigning official from any responsibility for past actions, but does relieve him from responsibility for anything undertaken thereafter. 


\section{Form 71.-Resignation of President.}

To the Board of Directors of the

Wiestern Electric Company.

Gentlemen,-I hereby resign my position as President and a Director of the Western Electric Company, my resignation to take immediate effect.

Respectfully,

James H. Walworth.

Chicago, Illinois,

September I0, 1909.

\section{Miscellaneous Instruments.}

It would seem preferable that all receipts for money received by a corporation should be given in the corporate name. In practice, however, corporate receipts are commonly signed by the treasurer. In such case the name of the corporation should appear prominently upon the instrument in order to indicate its corporate character.

\section{Form 72.-Corporate Receipt.}

Received from Edward M. Bogart Two Hundred and Fifty Dollars, rental of Store at No. 65 Vesey St. for September.

Webster Printing Company, By Samuel F. Watkins, Treasurer. 


\section{Form 73.-Corporate Bill of Sale.}

\section{Bill of Sale.}

\section{Know All Men By These Presents:}

That the Howard Printing Company, a corporation duly organized under the laws of the State of New York, with its principal office and place of business at No. 69 Murray Street, in the City of New York, in consideration of the sum of Fifteen Hundred ( $\$ 1500.00)$ Dollars to it paid by John C. Ralston of New York City, the receipt whereof is hereby acknowledged, does hereby sell, transfer and assign to the said Ralston the following goods and chattels, viz.:

The printing machinery, apparatus, type, type cases, stands and stock now in the premises at No. 69 Murray Street, New York City, occupied by the Howard Printing Company, all as set forth and specified in the annexed schedule; to have and to hold, all and singular, the said goods and chattels to the said Ralston, his successors and assigns, to their own use and behoof forever; and the said Howard Printing Company does hereby covenant with the said Ralston, grantee hereunder, that the said Howard Printing Company is the lawful owner of said goods and chattels; that they are free from all liens; that it has a good right to sell the same as aforesaid; and that it will warrant and defend the same against the lawful claims and demands of all persons. In Witness Whereof, the said Howard Printing Company has caused its corporate name to be signed hereunto by its President and its corporate seal to be affixed and duly attested by its Secretary, said corporate seal being affixed both to these presents and to the schedule hereunto annexed, all being done in the City of New York on this 5 th day of October, 1909.

$\left\{\begin{array}{c}\text { CORPORATE } \\ \text { SEAL }\end{array}\right\}$

Howard Printing Company, By Francis T. Howard, President.

\section{Attest Seal:}

John H. Sterling,

Secretary. 
The treasurer's bond was formerly a personal one, signed by the treasurer and his friends. Of recent years, however, companies have been formed for bonding purposes, and these surety company bonds have largely superseded the personal bond. The forms for surety company bonds are supplied by the surety companies and are too lengthy for inclusion in the present volume. A common form of personal bond is as follows :

Form 74.-Bond. Treasurer's.

TREASURER's Bond.

Know All Men By These Presents:

That we, Frank A. Pennington of Binghamton, New York, as principal, and John H. Seward and Samuel T. Williams, both also of Binghamton, as sureties, are held and firmly bound unto the Binghamton Creamery Company, a corporation duly organized under the laws of the State of New York, in the sum of Ten Thousand $(\$ 10,000)$ Dollars, to the payment of which to the said corporation, its successors or assigns, we do by these presents jointly and severally bind ourselves, our heirs, executors and administrators.

Signed and sealed this 25th day of August, I909.

The condition of the above obligation is that:

Whereas, The said Frank A. Pennington has been elected treasurer of the said Binghamton Creamery Company for the period of one year from the 2oth day of August, 1909, and may hereafter be re-elected to or continue in such office for a further period:

Now, Therefore, If the said Frank A. Pennington shall hereafter in all respects fully, faithfully and honestly perform and discharge the duties of said office so long as he shall continue therein, both during the term for which he has been elected and during such further time as he may continue therein, 
whether by re-election or otherwise, and shall when properly so required, fully and faithfully account to the said corporation, its successors or assigns, for all moneys, goods and properties whatsoever, for or with which the said Frank A. Pennington may in anywise be accountable or beholden to the said corporation, and if at the expiration of his term of or continuance in office, or prior thereto in the event of his death, resignation or removal from office, all books, papers, vouchers, money and other property whatsoever placed in his custody as Treasurer of said corporation shall be forthwith restored to the said corporation, its successors or assigns, then this obligation shall be void; but otherwise to remain in full force and effect.

Frank A. Pennington.

John H. SEWARd.

Samuel T. Williams.

[L. S.]

[L. S.]

Signed, Sealed and Delivered

in the Presence of:

Thomas HacketT.

GoRDON F. WILSON.

The treasurer's bond must be given under seal, and, while not legally necessary, personal bonds are usually acknowledged.

When a stock certificate is lost or destroyed, a bond of indemnity is usually required before the corporate authorities will replace the lost certificate. The following form is employed for this purpose:

\section{Form 75-Bond. Lost Stock Certificate.}

\section{INDEMNITy Bond.}

Know All Men By These Presents:

That we, Harry L. Lord of Yonkers, New York, as principal, and Thomas Frenkel and James P. Elder of New York City, 
as sureties, are held and firmly bound unto the Yonkers Hardware Company, a corporation duly organized under the laws of the State of New York, in the sum of Two Thousand $(\$ 2, \infty 00)$ Dollars, to the payment of which to the said corporation, its successors or assigns we do by these presents jointly and severally bind ourselves, our heirs, executors and administrators.

Signed and sealed this 2nd day of October, roog.

The condition of the foregoing obligation is that:

Whereas, The said Harry L. Lord is the owner of record, as shown by the stock book of the corporation, of Twenty (20) Shares of the Common Capital Stock of the said Yonkers Hardware Company, each of the par value of One Hundred (\$100) Dollars, the ownership of said stock being further evidenced by Certificate No. 482 issued in the name of the said Harry L. Lord on the Ist day of September, 1908; and

Whereas, The said Harry L. Lord has made application to the Board of Directors of the Yonkers Hardware Company for the issue in his name of a new certificate for the said Twenty (20) Shares of stock of the said Company, alleging that original Certificate No. 482 is lost, stolen or destroyed, and that its present whereabouts and condition are unknown to him; and

WhereAs, By due and formal resolution of the said Board of Directors, said application has been granted and a new certificate for said Twenty (20) Shares of the stock of the said Yonkers Hardware Company has this day been issued to the said Harry L. Lord:

Now, Therefore, If the said Harry L. Lord, his heirs, executors and administrators, or any of them, do and shall at all times hereafter, save, defend and indemnify the said Yonkers Hardware Company, its legal successors or assigns, of, from and against all demands, claims or causes of action arising from or on account of the loss of said Certificate No. 482 for Twenty (20) Shares of the Common Capital Stock of said Company, and the issue of said new certificate in place thereof, and of and from all costs, damages and expenses that shall or may arise because of said reissue, and shall also deliver or cause to be delivered up to the said Yonkers Hardware Company for cancellation the said missing Certificate No. 482 whenever and so soon as the same shall be found or recovered, or come into his 
possession, then this obligation shall be void; otherwise to remain in full force and effect.

$\begin{array}{ll}\text { HaRry L. LoRd. } & \text { [L. s.] } \\ \text { ThOMAS FrenKel. } & \text { [L. s.] } \\ \text { James P. Elder. } & \text { [L.s.] }\end{array}$

Signed, sealed and delivered

in the presence of:

EDGar WaLters.

LEONARD HOLCOMB.

Form 76.-Committee Report.

(See § 45.)

To THE BoARd OF Directors

of the Ellenville Woolen Mills Co.

Gentlemen :

Your committee appointed to investigate the cost of the proposed betterments of the Company's equipment and general plant begs leave to report as follows:

First. Your Committee finds that the present machinery and apparatus used in the mills of the Company is in thoroughly good condition, but that since its introduction better methods requiring apparatus of special design have been introduced, the difference being so radical that but little, if any, of the present installation can be retained.

Second. The cost of the proposed betterments will exceed the estimates of the stockholders' report submitted at a preceding meeting of the Board, aggregating not less than $\$ 60,000$. This larger cost is due to the radical nature of the improvements required, which necessitate material alterations and additions to the present buildings.

Third. Your Committee has gone a step beyond the immediate purposes of its appointment, having undertaken a general investigation of the conditions confronting the Company. We find, through this investigation, that the output of the Ellenville Mills 
is higher in cost and lower in quality than the output of similar mills better equipped, and this in the face of natural facilities that give the Ellenville Mills material advantages over these competitors.

In conclusion your Committee would strongly recommend the speedy introduction of the better equipment contemplated, not only as a matter of policy, but of necessity, as a continuance of the present conditions is likely to seriously and permanently injure the reputation and the prosperity of the Ellenville Mills. On the other hand the installation of the proposed improved equipment will not only maintain the business of the Company on the same satisfactory basis as heretofore, but will unquestionably result in materially increased profits.

Respectfully submitted,

William S. Symington.

Ellenville, New York, Herbert Wilson.

September 3, 1909.

(See Form 39.) 


\section{GENERAL INDEX}

[References are to pages.]

[For Titles of Forms, see Table of Contents.]

\section{A}

Acceptance of Subscriptions, 57, 58, 66, 179.

Acknowledgment, Corporate, 253, 260.

Forms, 253, 254.

of Charter, 135, 192.

Forms, 189-192, 195.

Adjourned Meetings, 147, 153.

Adjournment, 75, 147, 153.

Adoption of By-laws, 34, 39-42, 139, 140, 142, 143, 147.

Advantages of Corporate Form, 22-29.

Affidavit, Treasurer's,

Forms, 254.

Agent, Transfer, 62, 105, 115.

Agreements. (See Contracts.)

Amendment of By-laws, 41-43, 69.

Charter, 37, 38, 68, 163, 164.

Minutes, 111, 112, 245.

Annual Franchise Taxes, 137, 197, 198.

Annual Meeting of Stockholders. (See Meetings.)

Application for Charter. (See Certificate of Incorporation.) Approval of Minutes, 109-112.

Arizona Charter,

Forms, 192-195. 
[References are to pages.]

Articles of Association. (See Certificate of Incorporation.) Assets, Sale of Entire, 82, 222, 250.

Forms, 222, 223, 250.

Assignment in Blank, 61-63, 185, 186.

Forms, 185.

of Contract,

Forms, 260, 261.

of Property,

Forms, 277.

of Stock, 59, 62, 63, 114, 115, 185, 186, 264, 266.

Forms, 185, 186, 264, 265.

of Stock for Property, 60, 145, 146, 150, 151, 174, 175, 211-213, 216.

Forms, 210-213.

Attestation of Seal, 252, 260.

Auditor, 103.

Authority of Directors. (See Powers of Directors.)

\section{B}

Ballots, 78, 149, 272, 273.

Forms, 272, 273.

Bank Deposits, 119, 151, 152, 255.

Bill of Sale,

Forms, 277.

Board of Directors. (See Directors.)

Bond Issues, 119, 170.

of Indemnity, 64, 279.

Forms, 279-281.

of Treasurer, 101, 152, 219, 220, 278, 279.

Forms, 278, 279.

Books, Corporate, 59, 104-116, 137, 138, 176, 177, 262-267.

Changing to, 176, 177.

Dividend Book, 266, 267.

Forms, 266.

Inspection of, 68, 106, 156.

Minute Book, 105-112, 138.

Forms, 214-220, 233-244. 


\section{[References are to pages.]}

Books, Corporate.-Continued.

of Account, 104, 176, 177.

Secretary's Books, 59-65, 105-116, 137, 138, 233-244, 262-266.

Forms, 183-186, 214-220, 233-244, 263-265.

Stock Book. (See Stock Ledger.)

Stock Certificate Book, 59, 105, 112, 113, 138.

Forms, 183-186.

Stock Ledger, 65, 105, 115, 116, 137, 138, 262, 264.

Forms, 263.

Transfer Book, 65, 105, 114, 115, 137, 138, 264, 266.

Forms, 264, 265.

Treasurer's Books, 104, 105, 176, 177.

Business Corporations, 19.

Business, Order of, 201, 202.

By-laws, 39-44, 142, 143, 199-206.

Forms, 199-206.

Adoption of, 34, 39-42, 139, 140, 142, 143, 147.

Amendment of, 41-43, 69, 163, 164.

Certification of, 108, 152, 205.

Forms, 205.

Certified Extract from, 152, 255.

Forms, 206.

Enforcement of, 43, 44.

Non-observance of, 44.

Power to Make, 34, 40, 41, 91.

Record of, 41, 108, 143, 205.

C.

Cancellation of Stock Certificates, 63, 114.

Called Meetings. (See Special Meetings.)

Calls, 72, 73, 87, 140, 223-227.

Forms, 223, 226, 227, 241.

Calls and Waivers, 72, 73, 88, 140, 148, 149, 209, 210, 222, $225,226$.

Forms, 208, 210, 222, 223, 225, 226. 


\section{[References are to pages.]}

Capital, 48-50, 168.

Capitalization, 45, 48-50, 129, 167-170.

Capital Stock. (See Stock.)

Certificate of Incorporation, 23, 28, 30-38, 131-136, 187, 192.

Forms, 187-195.

Acknowledgment, 135, 192.

Forms, 189-192, 195.

Amendment of, 37, 38, 68, 163, 164.

Application for, 23, 30, 125-127, 131-136, 187.

Certified Copy, 107, 136.

Execution of, 126, 135, 189-192, 195.

Fees, 136, 137, 195, 196.

Filing, 135, 136.

Parties to, 66, 126, 127, 129, 132, 140-142, 171, 172, 192.

Powers, 23, 24, 31-37, 44, 128, 130, 133.

Purposes, 23, 24, 35, 128, 129.

Recording, 107, 135, 136, 142.

Special Provisions, 35, 36, 132-134.

Certificate of Secretary, 108, 205, 250, 255.

Forms, 205, 254-256.

Certificate of Stock, 18, 28, 45-48, 52, 58-64, 112-114, 182-186.

Forms, 183-186.

Adoption of, 152.

Assignment of, 59, 62, 63, 185, 186, 264, 266.

Forms, 185, 186, 264, 265.

Book, 59, 105, 112, 113, 138, 182-186.

Cancellation of, 63, 114.

Common Stock, 113.

Forms, 183.

Full-paid, 47, 58, 182.

Issue of, 47, 51, 60-62, 168.

Lost, 59, 63, 64, 279.

Preferred Stock, 113, 114, 185.

Forms, 184, 185.

Signatures, 47, 61, 101, 182.

Stub, 59, 61, 113, 114.

Forms, 183. 
[References are to pages.]

Certificate of Stock.-Continued.

Style, 182.

Transfer of, 28, 62, 63, 114, 115, 264, 266.

Forms, 185, 186, 264, 265.

Transfer Agent, 62, 105, 115.

Certification of By-laws, 108, 152, 205.

Forms, 205.

Charter, 136.

Certified Minutes, 108, 109, 250.

Forms, 256.

Resolution, 123, 151, 152, 250, 255.

Forms, 254, 255.

Transcript from By-laws, 152, 255.

Forms, 206.

Changing Books, 176, 177.

Charter. (See Certificate of Incorporation.)

Charter Powers. (See Powers.)

Checks, 99, 101, 119, 257.

Forms, 257.

Classification of Corporations, 16-21.

Directors, 85, 86, 160, 161.

Stock, 132, 159-161.

Close Corporations, 175, 176.

Closing Transfer Book, 266, 270.

Committees, Standing, 81, 92, 93, 131.

Common Stock, 53.

Forms, 183.

Company, Joint-Stock, 21.

Compensation of Directors, 90, 91, 96.

Officers, 96, 97, 134, 135, 150, 170.

Consent Meetings, 87-89.

Contracts, 83, 84, 122, 123, 170, 171, 249, 260.

Forms, 259, 260, 277.

Assignment of,

Forms, 260, 261.

Execution of, 122, 123, 260.

Signatures to, 123, 252, 260. 
[References are to pages.]

Corporate Acknowledgment, 253, 260.

Forms, 253, 254.

Advantages, 22-29.

Bill of Sale,

Forms, 277.

Books. (See Books.)

Checks, 99, 101, 119, 257.

Forms, 257.

Contracts. (See Contracts.)

Endorsement, 253.

Forms, 253.

Entity, 15, 16, 25, 26.

Management, 30-123.

Forms, 221-282.

Mechanism, 28-123.

Name, 127, 128, 167, 168.

Notes, 258, 259.

Forms, 258.

Organization, 124-177.

Forms, 178-220.

Permanence, 27, 34, 131.

Powers, 23, 24, 31-37, 44, 128, 130, 133.

Purposes, 23, 24, 35, 128, 129.

Receipts, 61, 276.

Forms, 276.

Seal, 32, 33, 121-123, 138, 260.

Attestation of, 252, 260.

Forms, 252.

Signatures, 251-253, 257-260. (See also Signatures.)

Forms, 251, 252.

System, 15-29.

Corporation, The, 15-21.

Corporations, Business, 19.

Classification of, 16-21.

Close, 175, 176.

Dissolution of, 27, 34, 35, 47, 131.

Distinctive Features, 22, 23. 


\section{[References are to pages.]}

Corporations. - Continued.

Domestic, 130.

Duration of, 27, 34, 130, 131, 136.

Financial, 20.

Foreign, 130, 166, 167.

Formation of, 19, 23, 28, 30, 31, 124-138, 166-174.

How Controlled, 39, 40, 139.

Limited Liability, 24, 25.

Limited Powers, 23, 24.

Nature, 15, 16, 25, 26.

Officers of. (See Officers.)

Offices of, 120, 121, 130.

Organization of, 28, 29, 40, 124-153, 155, 166-220.

Private, 16, 17.

Public, 16, 17.

Public Service, 19, 20.

Purposes, 23, 24, 35, 128, 129.

Quasi-Public, 17.

Stock, 18, 22-29.

Without Stock, 17, 18.

Correction of Minutes, 111, 112, 245.

Cost of Incorporation, 136, 137, 195, 196.

Equipment, 137, 138.

Counsel, 102, 103.

Cumulative Dividends, 53-55.

Voting, 76, 132, 133, 156-158, 273.

Forms, 273.

D

Debt, 118, 119, 134, 135, 163.

Deposits, Bank, 119, 151, 152, 255.

Directors, 80-93, 171-173.

Authority. (See Powers.)

By-laws, Power to Make, 39-41, 91, 140.

Classification, 85, 86, 160, 161.

Compensation, 90, 91, 96.

Contracts, 83, 84 . 


\section{[References are to pages.]}

Directors.-Continued.

Dummy, 84, 144, 171-173.

Duties, $80,81$.

Election, 33, 78, 80-81, 132, 133, 139, 140, 143, 144, 162, 214, 216, 270, 271. (See also Meetings.)

Executive Committee, 81, 92, 93, 131.

Failure to Elect, 81.

Finance Committee, 93.

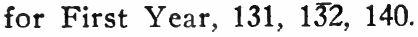

Liabilities, 37, 82-84, 112, 117, 275.

Meetings. (See Meetings.)

Method of Action, 82.

Number, 81, 82, 131.

Powers, 24, 28, 29, 33, 36, 37, 39-42, 80-82, 90, 91, 106, 117-119, 134, 135, 146, 155, 156.

Proxies, 86, 149.

Qualifications, 84, 132, 144, 171, 172.

Quorum, 89.

Removal, 85.

Resignation, 273-275.

Forms, 274.

Vacancies, 85, 275.

Dissolution of Corporation, 27, 34, 35, 47, 131.

Dividends, 53-55, 62, 63, 117, 118, 249.

Forms, 249.

Book, 266, 267.

Forms, 266.

Notice, 249, 269, 270.

Forms, 269, 270.

Domestic Corporations, 130.

Dummy Directors and Incorporators, 84, 127, 144, 171-173.

Duration of Corporation, 27, 34, 130, 131, 136.

Duties of Auditor, 103.

Counsel, 102, 103.

Directors, 80, 81.

General Manager, 102.

Officers, 97-103. 
[References are to pages.]

Duties of .-Continued.

President, 98, 99, 203, 248.

Secretary, 60-65, 100, 101, 105-116, 121, 203. (See also Secretary.)

Treasurer, 101, 102, 104, 105, 203, 204, 249, 268-270.

\section{$\mathbf{E}$}

Election, Inspectors of, 78, 143, 152, 153.

of Directors, $33,78,80,81,132,133,139,140,143,144$, $162,214,216,270,271$.

of Officers, 33, 89, 90, 94, 95, 149, 150, 270.

Endorsement, Corporate, 253.

Forms, 253.

Enforcement of By-laws, 43, 44.

Exchange of Property for Stock, 60, 145, 146, 150, 151, 174, $175,211-213,216$.

Forms, 210-213.

Execution of Charter, 126, 135, 189-192, 195.

Contract, 122, 123, 260.

Executive Committee, 81, 92, 93, 131.

Expenses of Incorporation, 136, 137, 152, 195, 196.

\section{F}

Face Value. (See Par Value.)

Failure to Elect Directors, 81.

Elect Officers, 90.

Send Notice of Meeting, 74, 88.

Fees and Taxation, 136, 137, 152, 195-198.

Tables, 195, 197.

Filing Charter, 135, 136.

Finance: Bank Deposits, 119, 151, 152, 255.

Debt, 118, 119, 134, 135, 163.

Dividends, 53-55, 62, 63, 117, 118.

Reserve Fund, 118, 168.

Surplus, 118.

Finance Committee, 93. 


\section{[References are to pages.]}

Financial Corporations, 20.

First Meeting of Directors, 148-153, 209-213, 216-220.

Adjournment, 153.

Calling Meeting, 148, 209, 210.

Forms, 210.

Election of Officers, 149, 150.

Exchange of Property for Stock, 60, 150, 151, 174, 175, 211-213, 216.

Forms, 210-213.

Financial Provisions, 151, 152.

Minutes, 145, 148, 150, 216, 219, 220.

Forms, 217-220.

Opening Meeting, 148, 149.

Other Business, 152, 153.

First Meeting of Stockholders, 132, 139-147, 207-216.

Adjournment, 147.

Adoption of By-laws, 139, 142, 143.

Calling Meeting, 140, 141, 209.

Forms, 208.

Conduct of Meeting, 141.

Election of Directors, 132, 139, 140, 143, 144.

Exchange of Property for Stock, 60, 145, 146, 174, 175, 211-213, 216.

Forms, 210-213.

Minutes, 141, 142, 145, 214, 216.

Forms, 214-216.

Opening Meeting, 142.

Preliminary, 139-141.

Reception of Charter, 142.

Foreign Corporations, 130, 166, 167.

Formation of Corporation, 19, 23, 28, 30, 31, 124-138, 166-174. Franchise Taxes, 137, 197, 198.

Full-Paid Stock, 51-53, 70, 168, 182.

Forms, 183-185.

General Manager, 102.

Guaranteed Stock, 54. 
[References are to pages.]

$\mathbf{H}$

Holding Stock in Other Corporations, 33, 133.

I

Illegal Purposes, 128, 129.

Incorporating a Partnership, 159, 160, 166-177.

Board of Directors, 171-173.

Business under New Form, 175, 176.

Capitalization, 167-170.

Changing Books, 176, 177.

Name, 127, 128, 167, 168.

Organization, 171-173.

Preliminary Contract, 170, 171.

Selection of State, 166.

Special Adjustments, 169, 170.

Transfer of Business, 174, 175.

Usual Arrangements, 168, 169.

Incorporation, 124-138.

Advantages of, 22-29.

Certificate of. (See Certificate.)

Cost of, 136, 137, 195, 196.

Domestic, 130.

Foreign, 130.

State of, 130, 166.

Incorporators, 66, 126, 127, 129, 132, 140-142, 171, 172.

Dummy, 127, 171, 172.

Indebtedness, Limitations on, 118, 119, 134, 135, 163.

Indemnity Bond, 64, 279.

Forms, 279-281.

Inspection of Books, 68, 106, 156.

Inspectors of Election, 78, 143, 152, 153.

Instalment Notice, 268.

Forms, 268, 269.

Issuance of Property for Stock. (See Exchange.)

Issue of Bonds, 119, 170.

Stock, 51, 60-62, 168, 174. 
[References are to pages.]

Issued Stock, 47, 50, 51 .

Irregular Procedure, 43, 44, 69, 122.

J.

Joint-Stock Corporation, 21.

L.

Law, Parliamentary, 71.

Ledger, Stock, 65, 105, 115, 116, 137, 138, 262, 264.

Forms, 263.

Liabilities of Directors, 37, 82-84, 112, 117, 275.

Officers, 37, 96, 275.

Stockholders, 24, 25, 52, 70.

Limitations on Salaries and Debt, 118, 119, 134, 135, 162, 163.

List, Subscription, 57, 124, 125, 178-181.

Forms, 178-180.

Location of Corporation, 120, 121, 130.

Lost Certificates, 59, 63, 64, 279.

Indemnity Bond, 279.

Forms, 279-281.

M.

Management of Corporation, 30-123.

Forms, 221-282.

Manager, General, 102.

Mechanism, Corporate, 28-123.

Meetings, Adjourned, 147, 153.

Adjournment, 75, 147, 153.

Ballots, 78, 149, 272, 273.

Forms, 272, 273.

Calls, 72, 73, 87, 140, 223-227.

Forms, 223, 226, 227, 241.

Calls and Waivers, 72, 73, 88, 140, 148, 149, 209, 222 , $225,226$.

Forms, 208, 210, 222, 223, 225, 226.

Consent, 87-89. 


\section{[References are to pages.]}

Meetings.-Continued.

Directors' First, 148-153, 209-213, 216-220.

Forms, 210-213, 217-220.

Adjourned, 153.

Regular, 86-90, 225.

Forms, 225, 237, 238.

Special, 87-89, 148, 225-227.

Forms, 225-227, 243, 244.

Failure of Notice, 74, 88.

Minutes of. (See Minutes.)

Notice of, 72-75, 87-89, 221-227.

Forms, 221, 222, 224, 225, 227, 241.

Officers of, 78, 79, 86, 87, 149, 150.

Opening of, 142, 148, 149.

Order of Business, 201, 202.

Place, 120, 121.

Proxies, 76-78, 86, 141, 149, 208, 228-232, 272, 273.

Forms, 207, 208, 228-231.

Publication of Notice, 74, 149, 221, 236.

Forms, 222.

Quorum, 75, 76, 89.

Record of, 105-116, 214-220, 233-244. (See also Minutes.)

Stockholders' Adjourned, 147.

Forms, 242, 243.

Annual, 71-79, 221, 236, 237, 272, 273.

Forms, 221, 222, 230, 231, 234-236, 272, 273.

First, 132, 139-147, 207-216.

Forms, 207, 208, 210-216.

Special, 72-79, 140, 222-224.

Forms, 222-224, 239-241.

Voting at, 48, 76, 132, 133, 143, 144, 149, 156-158, 273.

Minority, Protection of. (See Protection of.)

Rights of, 154, 155.

Minute Book, 105-112, 138.

Arrangement, 107, 108, 219, 220.

How Kept, 106, 107.

Style, 106.

Status, 106, 107. 
[References are to pages.]

Minutes, 105-112, 141, 142, 145, 148, 150, 214-220, 233-250.

Amendment of, 111, 112, 245.

Approval of, 110-112.

Book of, 105-112, 138. (See Minute Book.)

Certified, 108, 109, 123, 250.

Forms, 256.

Correction of, 111, 112, 245.

Directors' First, 145, 148-150, 216, 219, 220.

Forms, 217-220.

Regular,

Forms, 237, 238.

Special,

Forms, 243, 244.

Entry of, 107-110, 216, 219, 220, 233, 234, 246-250.

Reading, 110, 111, 141.

Signatures to, 110, 234.

Stockholders' Adjourned, 147.

Forms, 242, 243.

Annual, 236, 237.

Forms, 234-236.

First, 141, 142, 145, 214, 216.

Forms, 214-216.

Special,

Forms, 239-241.

Transcript of, 108, 109, 250.

Forms, 256.

Mortgages, 119, 121, 123.

Motions, 233, 245-248.

Forms, 246, 247.

N.

Name, Corporate, 127, 128, 167, 168.

Nature of Corporation, 15, 16, 25, 26.

New Jersey Charter, 192.

Forms, 190-192. 


\section{[References are to pages.]}

New York Charter,

Forms, 188-190.

Non-Stock Corporations, 17, 18.

Non-Voting Stock, 159, 160, 169, 170.

Notes, Corporate, 258, 259.

Forms, 258.

Notices, Failure to Send, 74, 88.

of Assessment, 268.

Forms, 268, 269.

of Directors' Meetings, 87-89, 148, 149, 225-227.

Forms, 225, 227.

of Dividends, 249, 269, 270.

Forms, 269, 270.

of Election as Director, 270, 271.

Forms, 270, 271.

of Stockholders' Meetings, 72-75, 140, 221-224.

Forms, 221, 222, 224, 241.

Publication of, 74, 149, 221, 236, 269, 270.

Forms, 222, 270.

Waiver of, 72, 73, 87-89, 140, 148, 149, 209, 222, 225, 226.

Forms, 208, 210, 222, 223, 225, 226.

Number of Directors, 81, 82, 131.

O.

Office, Principal, 120, 121, 130.

Officers, $33,80,89,90,94-103$.

Auditor, 103.

Counsel, 102, 103.

De Facto, 90.

Duties, 97-103, 200-204.

Election of, 33, 89, 90, 94, 95, 149, 150.

Failure to Elect, 90.

General Manager, 102.

Liabilities of, 37, 96, 275.

Necessary, 94.

of Meetings, 78, 79, 86, 87, 149, 150.

Powers, 29, 97-103, 122, 123. 


\section{[References are to pages.]}

Officers.-Continued.

President. (See President.)

Qualifications, 95.

Removal, 90, 95, 96.

Resignation, 273-275.

Forms, 276.

Salaries, 96, 97, 134, 135, 150, 170.

Secretary. (See Secretary.)

Signatures, 251-253, 257, 258, 260, 276.

Treasurer. (See Treasurer.)

Vacancies, 90, 95.

Vice-President, 99, 100.

Opening Meeting, 142, 148, 149.

Order of Business, 201, 202.

Organization of Corporation, 28, 29, 40, 124-153, 155, 166-220.

Forms, 178-220.

Expenses of, 136, 137, 152, 195, 196.

First Meetings, 28, 29, 139-153, 207-220.

Owners of Record, 58, 59, 62, 63, 66, 67, 117, 171, 172.

\section{$\mathbf{P}$}

Paid Up Stock. (See Full-Paid Stock.)

Parliamentary Law, 71.

Parties to Charter, 66, 126, 127, 129, 132, 140-142, 171, 172, 192.

Partnership, 21, 23, 25, 26, 32, 159, 160, 166-177.

Incorporation of, 159, 160, 166-177. (See Incorporating.)

Partnership Association, 21.

Par Value of Stock, 46, 47, 129.

Issue for Less than, 52, 53, 70.

Payment for Stock in Property. (See Exchange of Property for Stock.)

Powers, Charter, 23, 24, 31-37, 44, 128, 130, 133.

Illegal, 128, 129.

Special, 35, 36, 132-134.

to Appoint Directors, Officers and Agents, 33.

to Buy, Sell and Hold Property, 33. 


\section{[References are to pages.]}

Powers, Charter.-Continued.

to Dissolve Itself, 34, 35.

to Do All Things Necessary, 35.

to Make By-laws, 34.

to Sue and Be Sued, 32 .

to Use a Seal, 32, 33.

Powers of Directors, 24, 28, 29, 33, 36, 37, 39-42, 80-82, 90, 91. $106,117-119,134,135,146,155,156$.

Officers, 29, 97-103, 122, 123.

Stockholders, 28, 29, 34, 39-41, 68, 69.

Preferred Stock, 48, 53-55, 169, 170.

Certificate of, 113, 114, 185.

Forms, 184, 185.

Cumulative, 53-55.

Dividends, 53-55.

Participating, 169.

Redemption, 55, 170.

Rights of Holders of, 53-55, 68.

Voting Rights, 48.

President, 98, 99. (See also By-laws, 200-204.)

Call for Special Meeting, 226, 227.

Forms, 226, 227, 241.

Duties, 98, 99, 203, 248.

Powers, 98, 99.

Qualifications, 95.

Resignation, 275.

Forms, 276.

Signature, 251-253, 258.

Forms, 251, 252, 257-261.

Vice-, 99, 100.

Principal Office, 120, 121, 130.

Private Corporations, 16, 17.

Promissory Notes, 258, 259.

Forms, 258.

Property, Assignment of, Forms, 277.

for Stock. (See Exchange of.) 


\section{[References are to pages.]}

Property. - Continued.

Sale of Entire, 82, 250.

Forms, 250.

Protection of Minority, 154-165.

Classification of Stock, 160, 161.

Cumulative Voting, 76, 132, 133, 156-158.

Limitations on Expenditures, 118, 119, 134, 135, 162, 163.

Non-Voting Stock, 159, 160, 169.

Representation on Board, 155, 156.

Restrictions on Amendments, 163, 164.

Restrictions on Voting Power, 164, 165.

Voting Trusts, 161, 162.

Protest in Minutes, 112.

Proxies, 76-78, 86, 141, 149, 208, 228-232, 272, 273.

Forms, 207, 208, 228-231.

Blank, 228, 229.

Powers Conveyed, 228, 229.

Revocation of, 77, 228, 232.

Signature, 228.

Publication of Notice, 74, 149, 221, 236, 269, 270.

Forms, 222, 270.

Public Corporations, 16, 17.

Public Service Corporations, 19, 20.

Purposes, Charter, 23, 24, 35, 128, 129.

Illegal, 128, 129.

\section{Q.}

Qualifications of Directors, 84, 132, 144, 171, 172.

Incorporators, 126, 127.

Officers, 95.

Quasi-Public Corporations, 17.

Quorum at Directors' Meetings, 89.

Stockholders' Meetings, 75, 76.

$\mathbf{R}$.

Ratification of Unauthorized Action, 122. 
[References are to pages.]

Reading of Minutes, 110, 111, 141.

Receipt, Corporate, 61, 276.

Forms, 276.

Record, Owner of, 58, 59, 62, 63, 66, 67, 76, 117, 171, 172.

Recording By-laws, 41, 108, 143, 205.

Certificate of Incorporation, 107, 135, 136, 142.

Minutes, 105-112, 216, 219, 233-244, 246-250.

Motions and Resolutions, 246-248.

Regular Meetings, 71-79, 86-90. (See also Meetings.)

Removal of Directors, 85.

Officers, 90, 95, 96.

Reports, 109.

Forms, 281, 282.

Resignations, 273-275.

Forms, 212, 213, 255, 274, 276.

Resolutions, 145, 146, 150-152, 236, 237, 245-250.

Forms, 212, 213, 236, 242, 243, 248-250, 254, 255.

Certified, 123, 151, 152, 250, 255.

Forms, 254, 255.

Restrictions on Amendments, 163, 164.

Restrictions on Salaries and Debt, 118, 119, 134, 135, 162, 163.

Voting Power, 48, 164, 165.

Revocation of Proxy, 77, 228, 232.

Forms, 231.

Rights of Minority, 154, 155.

Rights of Stockholders, 43, 47, 57-59, 62-64, 67, 68, 76, 106, $112,154,155$.

\section{$\mathbf{S}$}

Salaries, Limitations on, 134, 135, 162, 163.

of Directors. (See Compensation of Directors.)

of Officers, 96, 97, 150, 170.

Seal, 32, 33, 121-123, 138, 260.

Attestation of, 252, 260.

Forms, 252.

Secretary, 61, 100, 101, 105-116, 121. (See also By-laws, 201203.) 


\section{[References are to pages.]}

Secretary.-Continued.

Books of, 59-65, 105-116, 137, 138, 214-220, 233-244, 262266.)

Forms, 183-186, 214-220, 233-244, 263-265.

Certificate of, 108, 205, 250, 255.

Forms, 205, 254-256.

Duties, 60-65, 100, 101, 105-116, 121, 203.

Affixing Seal, 61, 121, 252, 260.

Attestation of Seal, 252, 260.

Closing Transfer Book, 266, 270.

Correction of Minutes, 111, 112, 245.

Custodian, 33, 100, 106, 114, 121.

Issue of Stock, 60, 61, 64.

Notice of Meetings, 72-75, 87-89, 221-227, 241.

Proxies, 228, 232.

Reading Minutes, 110, 111.

Recording Minutes, 105-116, 216, 219, 233-244, $246-250$.

Transfer of Stock, 62, 63, 114, 115, 264, 266.

Signature, 251-253, 260.

Forms, 251, 252, 259, 261.

Shares. (See Stock.)

Signatures, Corporate and Official, 119, 251-253, 257, 258, 260, 276.

Forms, 251, 252.

to Contracts, 123, 260.

Forms, 252, 259.

to Notes, 258.

Forms, 258.

to Stock Certificates, 47, 61, 101, 182.

Forms, 183, 185.

Special Meetings, 72-79, 87-89, 140, 148, 222-227. (See also Meetings.)

Special Provisions in Charter, 35, 36, 132-134.

Classification of Stock, 132, 159-161.

Corporate Stockholding, 33, 133.

Cumulative Voting, 76, 132, 133, 156-158. 
[References are to pages.]

Special Provisions in Charter.-Continued.

Limitations on Salaries and Debt, 118, 119, 134, 135, $162,163$.

Standing Committees, 81, 92, 93, 131.

Stock, 18, 45-65, 129, 168, 169.

Assignment of, 59, 62, 63, 114, 115, 185, 186.

Forms, 185, 186.

in Blank, 61-63, 185, 186.

Forms, 185.

Book. (See Stock Ledger.)

Certificates of, 18, 28, 45-48, 52, 58-64, 112-114, 182-186.

Forms, 183-186.

Classification of, 132, 159-161.

Common, 53.

Corporation Holding, 33, 133.

Full-paid, 51-53, 70, 168.

Guaranteed, 54.

Issuance for Property. (See Exchange of Property for Stock.)

Issue of, 51, 60-62, 168, 174.

Issued and Outstanding, 47, 50, 51.

Ledger, 65, 105, 115, 116, 137, 138, 262, 264.

Forms, 263.

Minimum Amount, 129.

Non-Voting, 159, 160, 169, 170.

Par Value, 46, 47, 129.

Preferred, 48, 53-55, 169, 170, 185.

Shares of, 28, 45-50, 129.

Subscription to, 24, 51, 57-58, 66, 67, 124, 125, 132, 268.

Forms, 178-180, 268, 269.

System, 17, 18, 28, 29.

Transfer of, 28,62, 63,114, 115, 185, 186, 229, 264, 266.

Forms, 185, 186, 264, 265.

Treasury, 51, 56, 57, 118.

Unissued, 50, 51, 57.

Watered, 52, 53.

Stock Books, 59-65, 105, 137, 138, 262-266.

Stock Certificate Book, 59, 105, 112, 113, 138, 182-186.

Forms, 183-186. 


\section{[References are to pages.]}

Stock Certificates. (See Certificate of Stock.)

Stock Corporations, 18, 22-29.

Stockholders, 18, 45-48, 51, 66-79.

Liabilities of, 24, 25, 52, 70 .

Meetings of. (See Meetings.)

of Record, 58, 59, 62, 63, 66, 67, 76, 117, 171, 172.

Powers, 28, 29, 34, 39-41, 68, 69.

Rights, 43, 47, 57-59, 62-64, 67, 68, 106, 112, 154, 155.

Subscriptions, 24, 51, 57, 58, 66, 67, 124, 125, 132, 178-181, 268.

Forms, 178-180, 268, 269.

Acceptance of, 57, 58, 66, 179.

Notice of Assessment, 268.

Forms, 268, 269.

\section{T.}

Table of Franchise Taxes, 197.

Organization Expenses, 195.

Taxation, 137, 197, 198.

Testimonium Clause, 123, 252.

Forms, 252.

Transcript, Certified, from By-laws, 152, 255.

Forms, 206.

Minutes, 108, 109, 123, 250.

Forms, 256.

Transfer Agent, 62, 105, 115.

Transfer Book, 65, 105, 114, 115, 137, 138, 264, 266.

Forms, 264, 265.

Closing, 266, 270.

Transfer of Stock, 28, 62, 63, 114, 115, 185, 186, 229, 264, 266.

Forms, 185, 186, 264, 265.

Treasurer, 101, 102. (See also By-laws, 203, 204.)

Affidavit,

Forms, 254.

Bond of, 152, 219, 220, 278, 279.

Forms, 278, 279.

Books, 104, 105, 176, 177, 266, 267.

Duties, 101, 102, 104, 105, 293, 204, 249, 268-270. 


\section{[References are to pages.]}

Treasurer.-Continued.

Endorsement, 253.

Signature, 253, 257, 258, 276.

Forms, 253, 257, 258.

Treasury Stock, 51, 56, 57, 118.

Trusts, Voting, 161, 162.

U.

Ultra Vires, 24, 36, 37.

Unissued Stock, 50, 51, 57.

V.

Vacancies, Directors', 85, 275.

Officers', 90, 95.

Vice-President, 99, 100. (See also By-laws, 202, 203.)

Voting, 17, 18, 48, 76, 132, 133, 143, 144, 149, 156-159, 168, 169. Ballots, 78, 149, 272, 273.

Forms, 272, 273.

Cumulative, 76, 132, 133, 156-158, 273.

Forms, 273.

Preferred Stock, 48.

Proxies, 76-78, 86, 141, 149, 208, 228-232, 272, 273.

Forms, 207, 208, 228-231.

Restrictions on, 48, 164, 165.

Trusts, 161, 162.

W.

Waiver of Notice, 72, 73, 87-89, 140, 148, 149, 209, 222, 225, 226.

Forms, 208, 210, 222, 223, 225, 226.

Watered Stock, 52, 53.

Working Capital, 118, 168. 
\& 





\section{RETURN CIRCULATION DEPARTMENT}

$\underset{I O}{ } \rightarrow 202$ Main Library

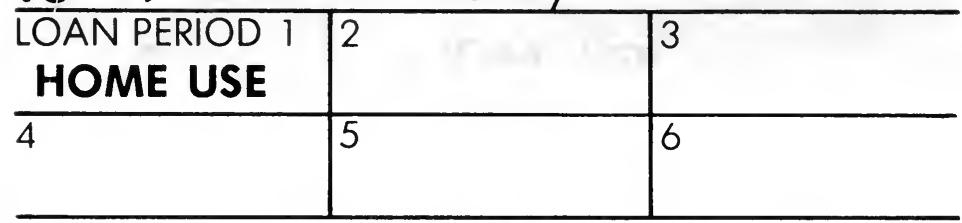

ALL BOOKS MAY BE RECALLED AFTER 7 DAYS

Renewals and Recharges may be made 4 days prior to the due date.

Books may be Renewed by calling $\quad 642-3405$

\section{DUE AS STAMPED BELOW}

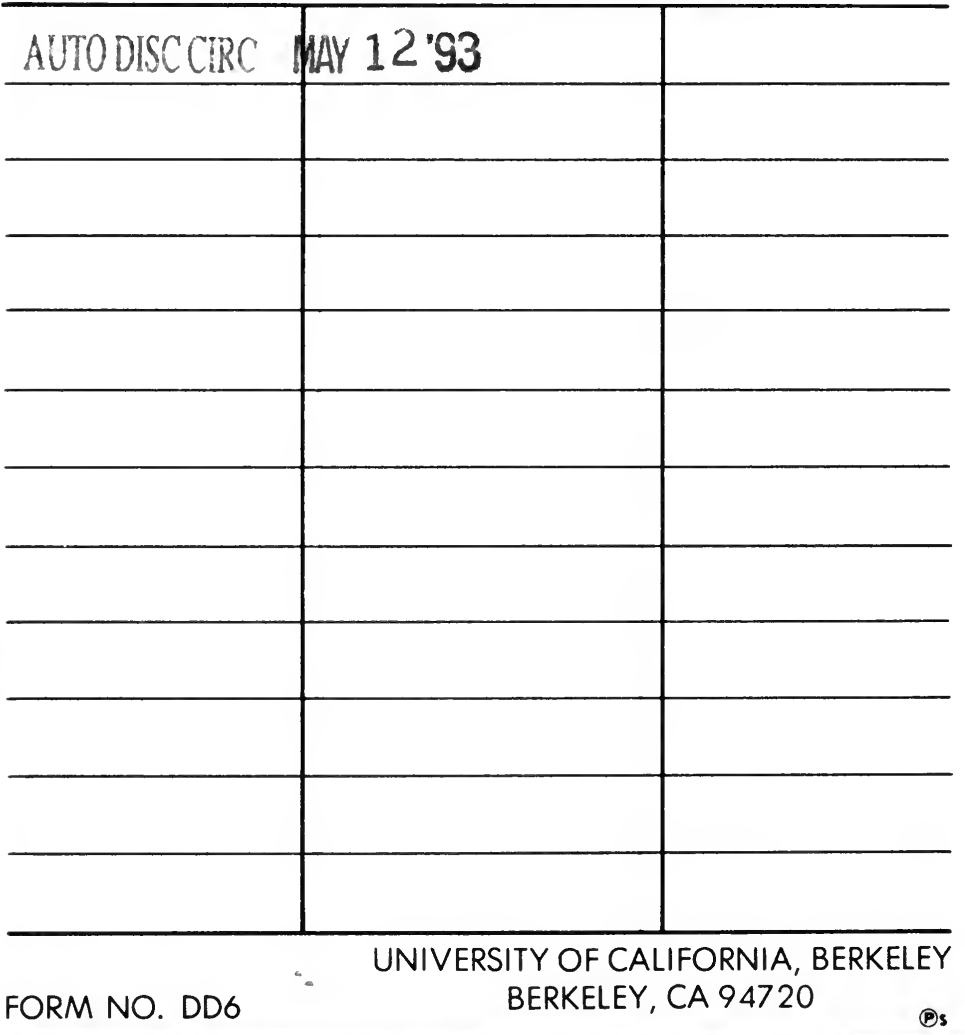


C042825552

a $\because \cdots$ 
